\author{
Aus der Abteilung Virologie \\ (Prof. Dr. med. F. T. Hufert) \\ im Zentrum Hygiene und Humangenetik \\ der Medizinischen Fakultät der Universität Göttingen
}

\title{
Entwicklung von
}

Rekombinase-Polymerase-Amplifikations-Nachweisverfahren

für virale Erreger von Atemwegsinfektionen

\author{
INAUGURAL-DISSERTATION \\ zur Erlangung des Doktorgrades \\ der Medizinischen Fakultät der \\ Georg-August-Universität zu Göttingen
}

\author{
vorgelegt von \\ Kai Ilmo Ehnts \\ aus \\ Hannover
}

Göttingen 2013 
Dekan: Prof. Dr. rer. nat. H. K. Kroemer

I.Berichterstatter: Prof. Dr. med. F. T. Hufert

II. Berichterstatterin: Prof. Dr. rer. nat. Bartels

III. Berichterstatter: Prof. Dr. med. Oppermann

Tag der mündlichen Prüfung: 06.08.2013 


\section{Inhaltsverzeichnis}

\section{Abkürzungsverzeichnis}

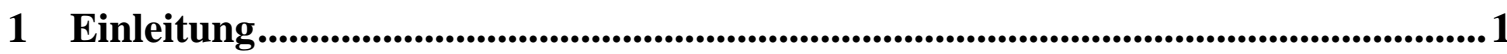

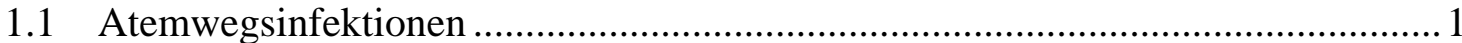

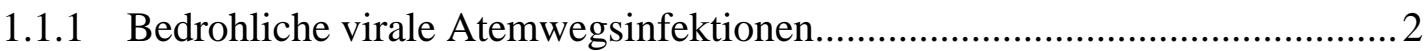

1.1.2 Exkurs: Geschichte der Influenza-Pandemien ..............................................4

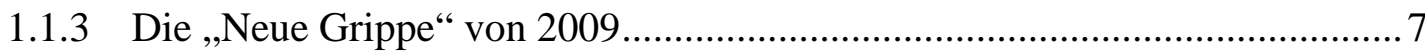

1.2 Orthomyxoviridae als Erreger viraler Atemwegsinfektionen................................ 8

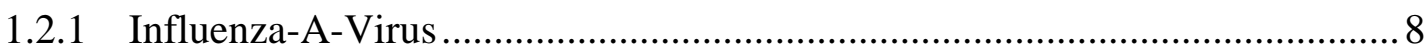

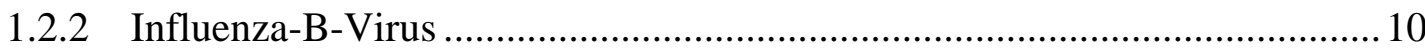

1.3 Humane Adenoviridae als Erreger viraler Atemwegsinfektionen ........................ 11

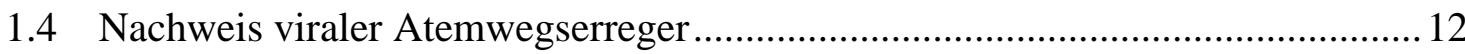

1.4.1 Nukleinsäure-Nachweisverfahren (NAAT) ................................................ 13

1.4.2 Bestehende Point-of-Care-Testverfahren....................................................... 14

1.5 Rekombinase-Polymerase-Amplifikation (RPA) …......................................... 15

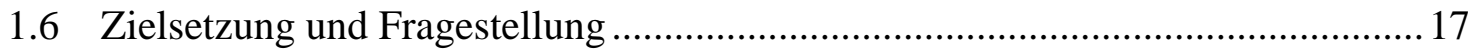

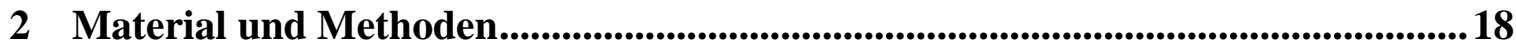

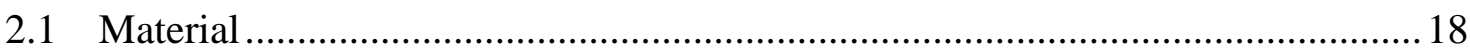

2.1.1 Verbrauchsmaterialien und Geräte ….......................................................... 18

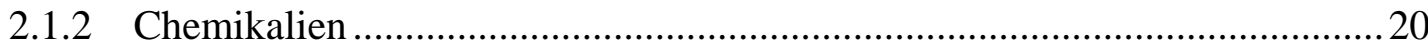

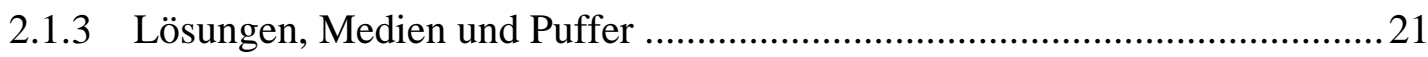

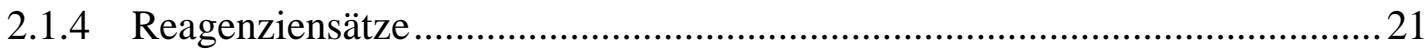

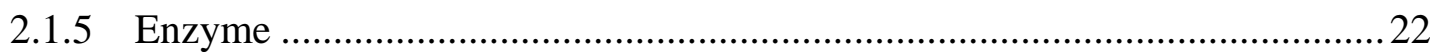

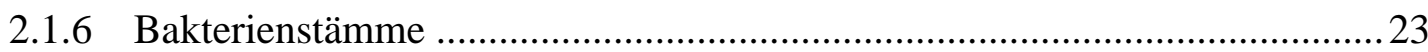

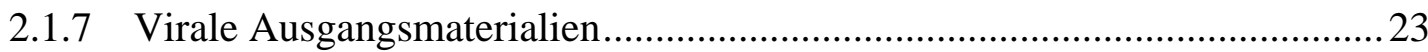

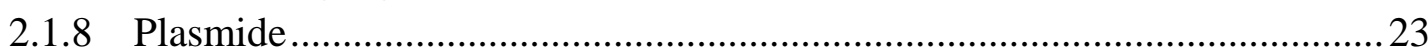

2.1.9 Oligonukleotide und Fluoreszenzsonden..................................................... 25

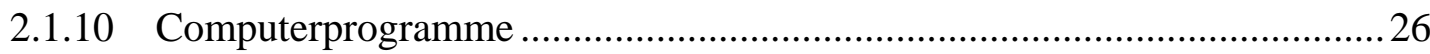

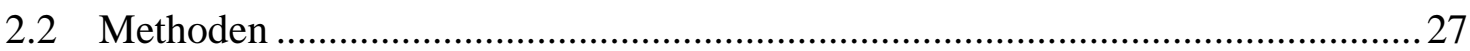

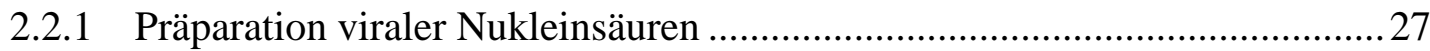

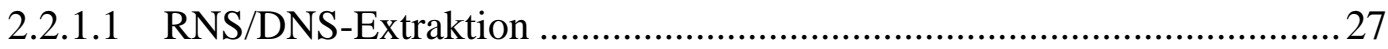

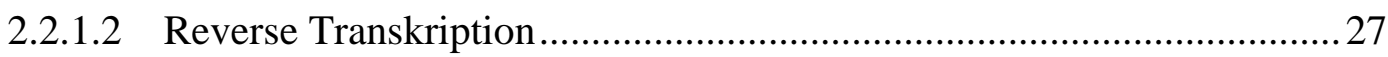

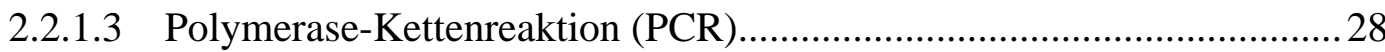

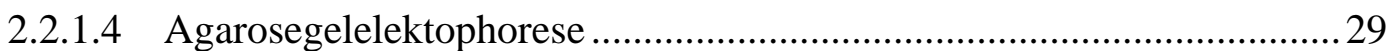

2.2.1.5 DNS-Extraktion aus präparativen Agarosegelen ..................................30

2.2.1.6 Ligation von dsDNS-Fragmenten .......................................................... 31

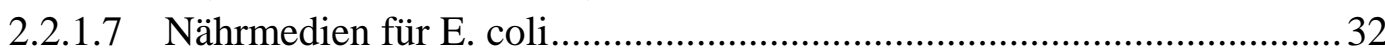


2.2.1.8 Tansformation von chemisch kompetenten E. coli-INV $\alpha F^{\prime}$-Bakterien 32

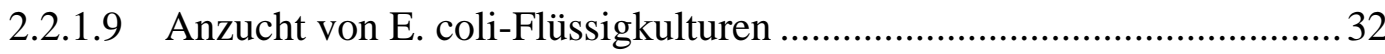

2.2.1.10 Anlage von Bakteriendauerkulturen ....................................................33

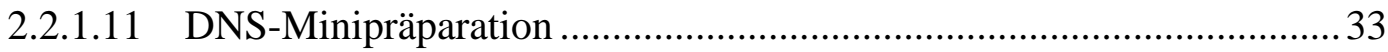

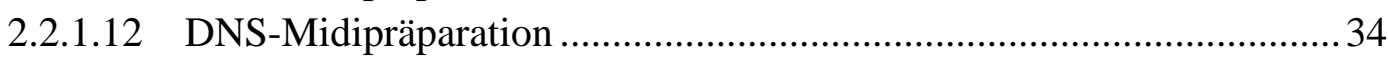

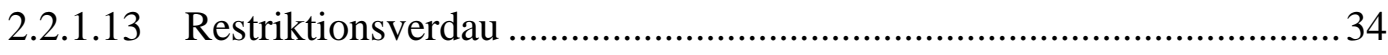

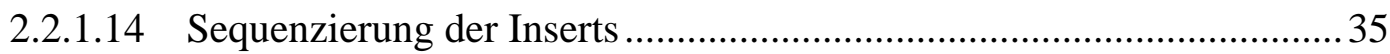

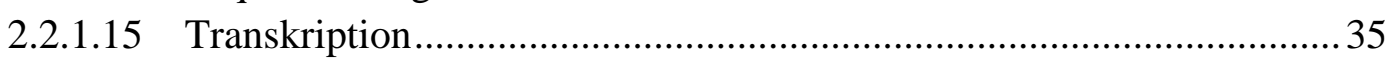

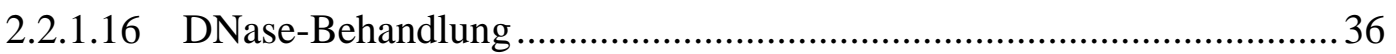

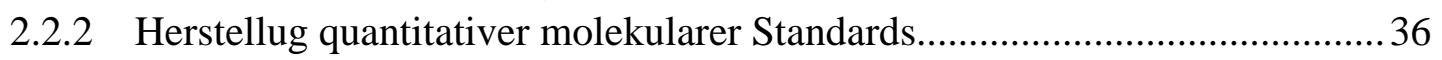

2.2.2.1 Spektrophotometrische Konzentrationsbestimmung ..............................36

2.2.2.2 PicoGreen ${ }^{\circledR}$-DNS-Konzentrationsbestimmung....................................... 36

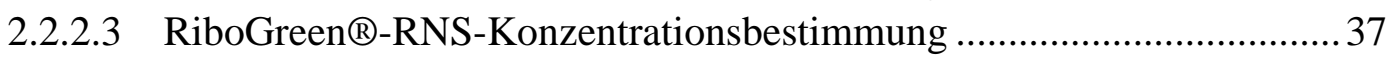

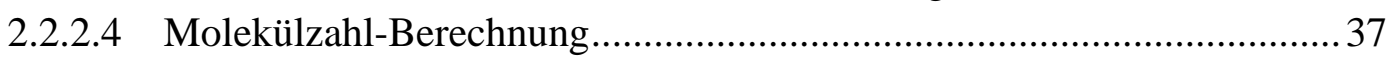

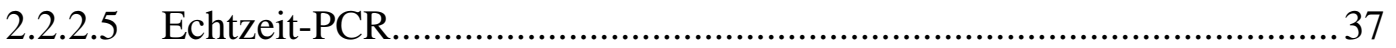

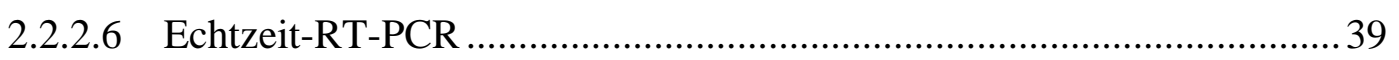

2.2.3 Rekombinase-Polymerase-Amplifikation................................................ 41

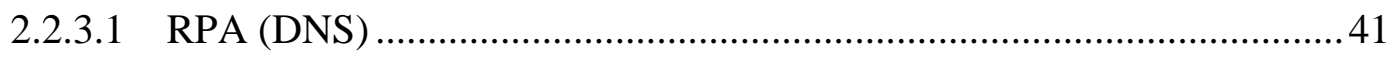

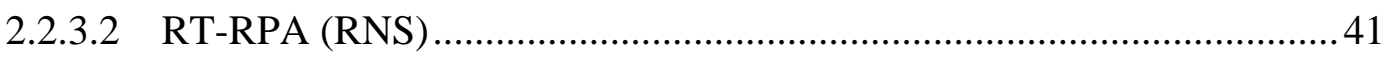

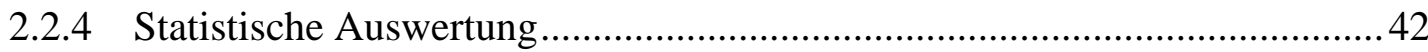

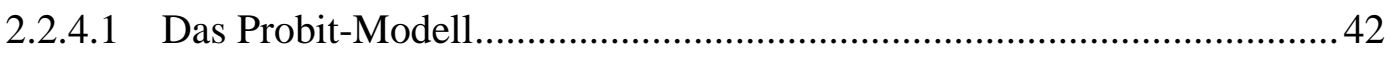

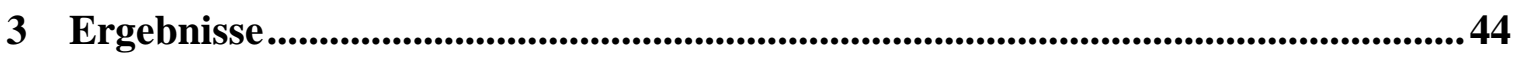

3.1 Rekombinase-Polymerase-Amplifikation von viraler RNS .................................44

3.1.1 Rekombinase-Polymerase-Amplifikation von Influenza-A-Virus ................. 44

3.1.1.1 Entwurf des Amplikons für den Nachweis von Influenza-A-Virus........ 44

3.1.1.2 Herstellung synthetischer Influenza-A-Standard-RNS ............................45

3.1.1.3 Evaluation der Influenza-A-RPA-Primerkandidaten ...............................49

3.1.1.4 Analytische Sensitivität der Influenza-A-RT-RPA .................................49

3.1.1.5 Analytische Spezifität der Influenza-A-RPA ..........................................51

3.1.2 Rekombinase-Polymerase-Amplifikation von Influneza-B-Virus ................. 52

3.1.2.1 Entwurf des Amplikons für den Nachweis von Influenza-B-Virus........5 52

3.1.2.2 Herstellung synthetischer Influenza-B-Standard-RNS ..........................5 52

3.1.2.3 Evaluation der Influenza-B-RPA-Primerkandidaten ..............................5 54

3.1.2.4 Analytische Sensitivität der Influenza-B-RPA ...................................... 54

3.1.2.5 Analytische Spezifität der Influenza-B-RPA......................................5 57

3.2 Rekombinase-Polymerase-Amplifikation von viraler DNS ...............................57

3.2.1 Rekombinase-Polymerase-Amplifikation humaner Adenoviren ....................57

3.2.1.1 Entwurf der Amplikons für den Nachweis humaner Adenoviren ..........57

3.2.1.2 Herstellung synthetischer Adenovirus-Standard-DNS ...........................5 57

3.2.1.3 Evaluation der HAdV-RPA-Primerkandidaten.......................................62

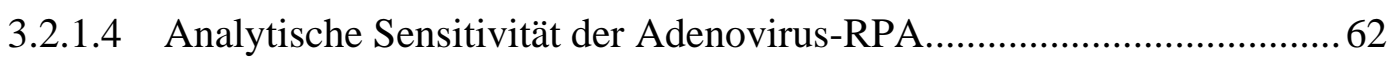

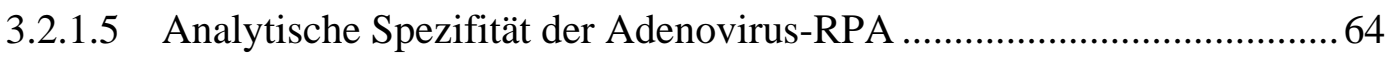




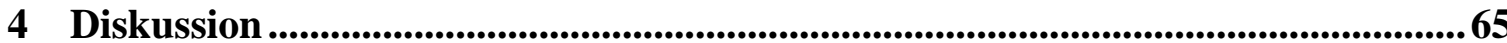

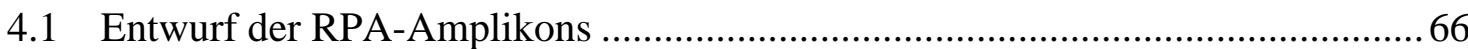

4.2 Sensitivitätsvergleich: RPA, Echtzeit-PCR und Alternativen .............................69

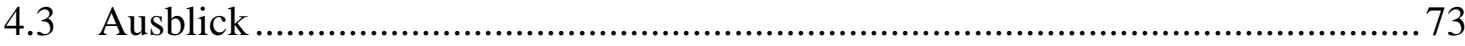

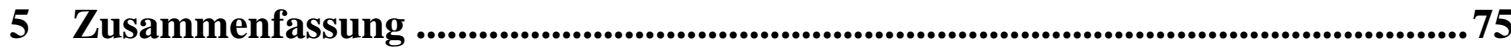

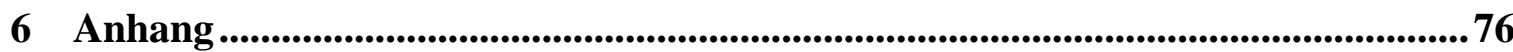

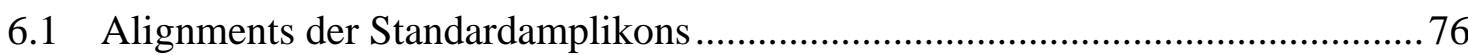

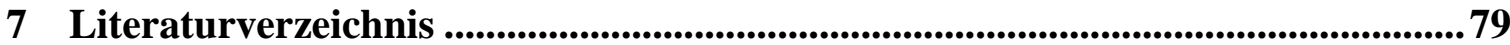

\section{Abkürzungsverzeichnis}

$\begin{array}{ll}\text { A } & \text { Adenin } \\ \text { Abb. } & \text { Abbildung } \\ \text { ad } & \text { auffüllen auf } \\ \text { Amp } & \text { Ampicillin } \\ \text { AP-Stelle } & \text { Apurinische/Apyrimidinische Stelle } \\ \text { ATP } & \text { Adenosin-Triphosphat } \\ \text { BBQ } & \text { BlackBerry }{ }^{\circledR} \text { Quencher } \\ \text { BHQ } & \text { BlackHole }{ }^{\circledR} \text { Quencher } \\ \text { BLAST } & \text { Basic Local Alignment Search Tool } \\ \text { bp } & \text { Basenpaar(e) } \\ \text { BSA } & \text { Bovines Serum-Albumin (Rinderserumalbumin) } \\ \text { bzw. } & \text { beziehungsweise } \\ \text { C } & \text { Cytosin } \\ \text { cDNS } & \text { komplementäre DNS } \\ \text { CP } & \text { Crossing Point } \\ \text { ddH }{ }_{2} \mathrm{O} & \text { doppelt-destilliertes Wasser }\end{array}$


DNS Desoxyribonukleinsäure

dNTPs Desoxynukleosidtriphosphate (dATP, dGTP, dCTP, dTTP)

ds Doppelstrang-

DTT Dithiothreitol

E. coli Escherichia coli

EDTA Ethylendiamintetraacetat-Dinatriumsalz

Endkonz. Endkonzentration

EtOH Ethanol

FAM Fluorescein

G Guanin

g Erdbeschleunigung (ca. 9,81 m/ $/ \mathrm{s}^{2}$.)

h Stunde

HAdV Humanes Adenovirus

HDA Helicase-Dependent Amplification

ILI Influenza-like illness

kb Kilobasen

l Liter

LAMP Loop-Mediated Isothermal Amplification

Lsg. Lösung

M $\quad$ molar $=\mathrm{mol} / \mathrm{l}$

$\mu \quad$ Mikro-, $10^{-6}$

mg Milligramm

$\min \quad$ Minute

ml Milliliter

$\mathrm{mM} \quad$ millimolar

NAAT Nucleic acid amplification test

NASBA Nucleic Acid-Based Amplification

nm Nanometer

nt Nukleotide

OD Optische Dichte

PCR Polymerase-Kettenreaktion

pH negativer dekadischer Logarithmus der H+-Ionenkonzentration 


\begin{tabular}{|c|c|c|}
\hline \multicolumn{2}{|c|}{ Abkürzungsverzeichnis } & \multirow[t]{2}{*}{$\mathrm{V}$} \\
\hline PoC & Point-of-Care / Patientennahe Diagnostik & \\
\hline RCA & Rolling Circle Amplification & \\
\hline RNS & Ribonukleinsäure & \\
\hline RPA & Rekombinase-Polymerase-Amplifikation & \\
\hline RSV & Respiratorisches Synzytial-Virus & \\
\hline RT & Reverse Transkriptase & \\
\hline RT-PCR & Reverse-Transkriptase-Polymerase-Kettenreaktion & \\
\hline SDA & Strand Displacement Amplification & \\
\hline sec & Sekunde & \\
\hline SMART & Signal Mediated Amplification & \\
\hline SPIA & Single Primer Isothermal Amplification & \\
\hline SS & Einzelstrang- & \\
\hline $\mathrm{T}$ & Thymin & \\
\hline Tab. & Tabelle & \\
\hline TAE & Tris-Acetat-EDTA-Puffer & \\
\hline Taq & Thermus aquaticus & \\
\hline THF & Tetrahydrofuran & \\
\hline TE & Tris-EDTA-Puffer & \\
\hline $\mathrm{T}_{\mathrm{m}}$ & Schmelztemperatur & \\
\hline TMA & Transcription Mediated Amplification & \\
\hline Tris & Tris-(hydroxymethyl)-aminomethan & \\
\hline tRNS & Transfer-Ribonukleinsäure & \\
\hline $\mathrm{U}$ & Unit & \\
\hline ü.N. & über Nacht & \\
\hline UpM & Umdrehungen pro Minute & \\
\hline USA & Vereinigte Staaten von Amerika & \\
\hline UV & Ultraviolett & \\
\hline $\mathrm{V}$ & Volt & \\
\hline $\mathrm{v} / \mathrm{v}$ & Volumenverhältnis (volume/volume) & \\
\hline $\mathrm{w} / \mathrm{v}$ & Gewichtsverhältnis (weight/volume) & \\
\hline X-Gal & 5-Brom-4-chlor-3-indolyl- $\beta$-D-galactopyranosid, $\mathrm{C}_{14} \mathrm{H}_{15} \mathrm{BrClNO}_{6}$ & \\
\hline z.B. & zum Beispiel & \\
\hline
\end{tabular}


Alle chemischen Elemente wurden mit den üblichen Symbolen abgekürzt. Geschützte Warennamen wurden nicht kontinuierlich kenntlich gemacht. Aus dem Fehlen eines solchen Hinweises kann nicht geschlossen werden, dass es sich um freie Warennamen handelt. 


\section{$1 \quad$ Einleitung}

\subsection{Atemwegsinfektionen}

Die Symptome einer Atemwesinfektion wie Husten, Schnupfen, Heiserkeit und allgemeines Krankheitsgefühl sind besonders in den Wintermonaten ein sehr häufiger Grund für Arztkonsultationen und Krankschreibungen. Dabei muss jeder Atemwegsinfekt ernst genommen werden, da der Symptomatik durchaus verschiedenste lebensbedrohliche Krankheitsbilder wie zum Beispiel Influenza, das respiratorische Synzytial-Virus (RSV), bakterielle Pneumonien oder Adenovirusinfektionen zugrunde liegen können.

Atemwegsinfektionen können sowohl bakteriell als auch viral bedingt sein. In der überwiegenden Mehrzahl der Fälle handelt es sich um unkomplizierte virale Infektionen im Sinne einer einfachen Erkältung. Dennoch werden, nicht zuletzt aufgrund der unspezifischen Symptomatik, von niedergelassenen Ärzten häufig Antibiotika zur Prophylaxe oder Therapie einer eventuellen Sekundärinfektion verschrieben (Vogel 2011). Besonders die Gefahren, die sowohl von der saisonalen als auch von der pandemischen Influenza ausgehen, sind seit langem bekannt. Dennoch werden sie, sowohl in der Bevölkerung als auch von Ärzten, immer noch unterschätzt, was beispielsweise an der unscharfen Verwendung von Krankheitsbezeichnungen wie „grippaler Infekt“, „Grippe“, und „Erkältung“ deutlich wird. Auch gibt es mit der Impfung eine wirksame Prophylaxe gegen die saisonale Influenza, die jedoch wenig genutzt wird. Das Robert Koch Institut hat 2008 bei einer Priorisierung von Krankheitserregern das Influenza-A-Virus an erster Stelle, noch vor HCV, HIV und MRSA, eingeordnet (Krause 2008). In einer weiteren Veröffentlichung von 2011 werden Atemwegserreger wie Influenza und RSV in die Gruppe mit höchster Priorität und Adenoviren sowie Parainfluenzaviren in die Gruppe mit hoher Priorität eingeordnet (Balabanova et al. 2011). Seit der Einführung der Virustatika der Klasse der Neuraminidaseinhibitoren steht eine spezifische Behandlungsmöglichkeit der Influenza zur Verfügung. Diese sind am wirksamsten, wenn die Behandlung möglichst frühzeitig begonnen wird. Eine Therapie sollte spätestens 48 Stunden nach Symptombeginn erfolgen. Daher ist der Arzt auf eine schnelle Diagnosesicherung angewiesen. Die zurzeit vorhandenen Schnelltests können dies nicht mit der ausreichenden Sensitivität leisten und 
finden keine flächendeckende Anwendung. Die zeitaufwendige, meist in externen Laboren durchgeführte Diagnostik viraler Atemwegserkrankungen kann aufgrund der verspätet vorliegenden Ergebnisse den Krankheitsverlauf in der Regel nicht positiv beeinflussen (Wishaupt et al. 2011). Der isothermale Nachweis viraler Nukleinsäuren mittels Rekombinase-Polymerase-Amplifikation könnte als Instrument zur schnellen und sensitiven Diagnosestellung „am Krankenbett“ diese Lücke der Versorgung schließen und eine effizientere Behandlung von Atemwegsinfektionen ermöglichen.

\subsubsection{Bedrohliche virale Atemwegsinfektionen}

Wie bereits erwähnt, ist die Mehrzahl der Atemwegsinfektionen viraler Genese. Es handelt sich überwiegend um selbstlimitierende Erkältungskrankheiten, die von verschiedensten Erregern wie Rhino-, Entero- oder Coronaviren ausgelöst werden können. Dabei kann es zu Komplikationen im Sinne einer bakteriellen Superinfektion kommen, die eine antibiotische Therapie erforderlich machen. Einige Viren führen jedoch auch selbständig zu schweren Verläufen.

Die durch Influenzaviren vom Typ A und B verursachte typische klinische Symptomatik wird unter dem Oberbegriff der sogenannten influenza-like illness (ILI) zusammengefasst. Dabei kommt es nach einer Faustregel bei rund einem Drittel der Erkrankten zu einem fieberhaften Verlauf, ein Drittel der Erkrankungen verlaufen leichter und etwa ein Drittel der Infizierten bleibt asymptomatisch (Robert-Koch-Institut 2011). Das Vollbild der ILI ist besonders durch den plötzlichen Symptombeginn mit Fieber, Halsschmerzen, trockenem Husten sowie Muskel- und Kopfschmerzen gekennzeichnet. Es können außerdem gastrointestinale Symptome wie Übelkeit und Erbrechen auftreten. Bei komplikationslosem Verlauf beträgt die Erkrankungsdauer rund eine Woche.

Die typische Komplikation der Influenza ist die Pneumonie, entweder durch das Virus selbst oder durch bakterielle Superinfektionen ausgelöst. Des Weiteren kann es bei vorbestehenden chronischen Lungenerkrankungen zur Exazerbation kommen. Außerdem können Myokarditis, Myositis, Rhabdomyolyse und Enzephalitis auftreten. Allgemein sind derartige Komplikationen jedoch selten und betreffen vor allem chronisch vorerkrankte, ältere Patienten. Auch Kinder haben ein erhöhtes Risiko, eine Komplikation zu erleiden. Besonders häufig tritt bei ihnen, aufgrund der besonderen anatomischen Verhältnisse, die Otitis media auf. Allein in der Saison 2004/05 führte die saisonale 
Influenza in Deutschland zu geschätzten 4,8 bis 6,2 Millionen Arztbesuchen, 1,8 bis 2,4 Millionen Arbeitsunfähigkeiten und 22000 bis 32000 Krankenhauseinweisungen. In den 10 vorausgegangenen Jahren hat sie zu 6000 bis 17000 Todesfällen jährlich geführt (Haas et al. 2005).

Weitere wichtige Erreger influenzaartiger Atemwegsinfektionen sind humane Adenoviren. Die 57 bekannten Serotypen dieses Virus können die verschiedensten Krankheitsbilder verursachen. Insbesondere akute respiratorische Erkrankungen und lebensbedrohliche virale Pneumonien stellen eine wichtige Differentialdiagnose zur Influenza dar. Des Weiteren können Pharyngitis, Keratokonjunktivitis Epidemica, Hämorrhagische Zystitis, Hepatitis und Gastroenteritis durch Adenoviren hervorgerufen werden (Echavarria et al. 1999).

Bei fieberhaften Atemwegsinfektionen muss auch das Respiratorische Synzytial-Virus (RSV) differentialdiagnostisch in Betracht gezogen werden, das ein breites Spektrum an Symptomen, von Erkältungsbeschwerden bis zu lebensbedrohlichen Pneumonien, hervorrufen kann. Es ist hoch ansteckend und betrifft in der Regel Kinder im ersten Lebensjahr, bei welchen es das gefürchtete Krankheitsbild der Bronchiolitis auslösen kann (Welliver 2003). Es kann jedoch auch bei Erwachsenen, besonders bei älteren und vorerkrankten, zu lebensbedrohlichen kardialen und pulmonalen Komplikationen führen. In den USA verursachten RSV-Infektionen im Zeitraum von 1990 bis 1999 jedes Jahr um die 17000 Todesfälle (Thompson et al. 2003).

Besonders bei Kleinkindern unter vier Jahren kann eine der Influenza ähnliche Symptomatik auch durch humane Parainfluenzaviren verursacht werden. In dieser Patientengruppe sind sie die Hauptverursacher des Pseudokrupp. Bei diesem Krankheitsbild ist neben allgemeinen Atemwegsbeschwerden ein bellender Husten charakteristisch, wie er auch bei der Diphterie (echter Krupp) auftritt. Durch die ödembedingte Einengung der noch nicht ausgereiften Atemwege im Kehlkopfbereich kommt es zu Atemnot, die in Extremfällen eine Intubation erforderlich machen kann. Seltener kommt es zu Bronchitis und Brochiolitis. Im Erwachsenenalter verlaufen Reinfektionen mit Parainfluenzaviren aufgrund der hohen Durchseuchungsrate in der Regel milde (Modrow 2010, S.298). 


\subsubsection{Exkurs: Geschichte der Influenza-Pandemien}

Die Influenza ist eine klassische Seuche, die sowohl in Form lokal begrenzter Epidemien als auch in Form pandemischer Ausbrüche seit mindestens 500 Jahren auftritt (Morens und Taubenberger 2011). Sie kommt sowohl bei Menschen als auch bei Tieren wie Schweinen, Pferden, Hunden und verschiedenen Vögeln vor. Von einer Epidemie spricht man bei einem zeitlich und örtlich begrenzten Krankheitsausbruch mit einer Infektionsrate von 10-20 \% der Gesamtbevölkerung, wie er im Winter in Form der saisonalen Influenza vorkommt. Allein diese Form der Erkrankung verursacht in Deutschland mehrere Tausend Todesfälle jährlich (Robert-Koch-Institut 2009b). Bei einer Pandemie kommt es zu einem örtlich nicht begrenzten d.h. Länder- und Kontinente übergreifenden Auftreten. Dies ist bei Influenza-A-Viren offenbar alle 10-40 Jahre möglich und wird mit dem Mechanismus der Antigen-Shift und dem Überdauern der Erreger in Tierreservoirs in Verbindung gebracht. Die pandemisch auftretende Grippe geht mit einer vielfach erhöhten Erkrankungs- und Sterblichkeitsrate einher als die saisonale Influenza. Das gesamte Ausmaß der Tragweite dieser, in weiten Teilen immer noch unerklärten, Anpassungsfähigkeit der Influenza wird erst durch die Betrachtung ihrer Geschichte ersichtlich.

Die Symptome der Influenza und besonders die Begrifflichkeiten zu deren Beschreibung sind im historischen Kontext nicht eindeutig genug, um das erste epi- oder pandemische Auftreten der Grippe in der Menschheitsgeschichte klar zu benennen. Auf dem Gebiet des heutigen Deutschland kann das in den Annalen von Fulda beschriebene italienische Fieber des Winters 877 als erster überlieferter Ausbruch einer Erkrankung mit typischer Symptomatik gewertet werden (Jankrift 2003). Im 16. Jahrhundert sind drei Influenzaartige Pandemien beschrieben, wobei die Erkrankung der Nutztiere, vor allem Pferde, den menschlichen Fällen einige Wochen vorausging (Morens und Taubenberger 2010). Verlässlichere Aussagen lassen sich erst ab Beginn des 18. Jahrhunderts treffen. Von Martiny wurde 1835 eine Epidemie beschrieben, welche sich 1781 von China ausgehend innerhalb eines Jahres über Sibirien nach Europa ausbreitete. Diese Erkrankung manifestierte sich insbesondere durch

\footnotetext{
„Abgeschlagenheit, Kopfschmerzen, [...] Schwindel, febrilische, catarrhalische und rheumatische Erscheinungen, leichtes Delirium gegen Abend, Ekel, häufiger, voller zuweilen weicher Puls, schneller Athem, Verstopfung, rother Urin. Mit der Crisis trat ein säuerlich-übelriechender Schweiß und Excretion des Lungenschleims und eines trüben Urins mit ziegelartigem Bodensatz, in anderen Fällen mit weißen Wölkchen ein“ (Martiny 1835, zitiert nach: Witte 2009, S. 3).
} 
Die damals durchgeführten Therapieversuche mit Aderlässen, Kampfer, Expektoranzien oder Opiaten vermochten Dauer und Verlauf der Erkrankung nicht positiv zu beeinflussen. So war es oft ein Problem, dass kein Gesunder mehr verfügbar war, um die Masse der Erkrankten zu pflegen (Witte 2009).

Die erste Grippe Pandemie im Zeitalter der Zellularpathologie war die sogenannte „Russische Grippe“ der Jahre 1889-1892. Sie begann 1889 im russischen Generalgouvernement Turkestan und fand einen ersten Höhepunkt der Ausbreitung in Europa und Nordamerika Anfang 1890. Eine zweite Erkrankungswelle hatte ihren Höhepunkt im Frühling 1891 und eine dritte Anfang 1892. In Europa verstarben im Verlauf der Pandemie 270000 bis 300000 Menschen, meist an respiratorischen Komplikationen (Witte 2009). Im Zusammenhang mit dieser Pandemie wurde 1890 erstmals von Henri Huchard (1844-1910) eine Beteiligung des Herzens am Krankheitsgeschehen postuliert (Wolf 1892). Eine Neuerung in der Therapie der Influenza war der weit verbreitete Einsatz des nichtsteroidalen Antiphlogistikums Antipyrin ${ }^{\circledR}$ (Wirkstoff: Phenazon) der Farbwerke Hoechst, einer Vorläufersubstanz des Metamizol. In Folge der „Russischen Gippe“ entdeckte Richard Pfeiffer (1858-1945), ein Mitarbeiter von Robert Koch (1843-1910), 1892 ein hämophiles Bakterium, das bis heute als Haemophilus influenzae bezeichnet wird. Seine Annahme, es sei der Erreger der Grippe, wurde daraufhin zur Lehrmeinung (Pfeiffer 1892).

Die verheerendste und bekannteste Grippe-Pandemie der Geschichte ist die durch Influenza A/H1N1 hervorgerufene sogenannte „Spanische Grippe“ der Jahre 1918-1920. Sie forderte nach konservativen Schätzungen weltweit 27-50 Millionen Menschenleben (Johnson und Mueller 2002). Im Deutschen Reich verstarben rund 300000 Menschen an der Spanischen Grippe (Witte 2009). Als Ursprungsort der Pandemie wird Camp Funston in Kansas in den USA angenommen, von wo die erste Erkrankungswelle im Frühjahr 1918 ausgegangen sein soll. Die Bezeichnung „Spanische Grippe“ ist wohl am ehesten darauf zurückzuführen, dass das nicht am ersten Weltkrieg beteiligte Spanien, anders als andere europäische Länder, eine freie Berichterstattung über die Seuche zuließ. Die Therapieversuche, welche sich immer noch auf die Annahme eines bakteriellen Erregers stützten, beinhalteten neben dem Einsatz nichtsteroidaler Antiphlogistika, Codien, Heroin und Epinephrin, den Verzehr von Roter Beete, Kalziumtabletten, Strychnin sowie intragluteale Milchinjektionen zur Behandlung der Leukopenie. Besonders auffällig ist, 
dass anders als bei früheren Pandemien, viele junge Patienten im Alter zwischen 20 - 40 Jahren verstarben und die Mortalität in indigenen Bevölkerungen überproportional hoch war.

Nach der Entdeckung des Influenza-Virus im Jahre 1933 durch Andrewes, Smith und Laidlaw (Andrewes et al. 1934) bildete sich die Virologie immer mehr als eigenständiger Wissenschaftszweig heraus. „Die Jahre 1935 bis 1960 waren die Zeit, in der das Grippevirus das meisterforschte, quasi prototypische Virus war“ (Witte 2009, S.17).

Die erste Grippepandemie nach Etablierung der Virologie als Wissenschaft war die sogenannte „Asiatische Grippe“ der Jahre 1957-1958, verursacht durch Influenza A/H2N2. Diese Pandemie verbreitete sich im Februar 1957 von China ausgehend und erreichte Berlin im November desselben Jahres. Ihre Ausbreitungsgeschwindigkeit war damit deutlich höher als die vorangegangener Ausbrüche. Weltweit forderte die „Asiatische Grippe“ rund eine Million Menschenleben (Schmager 1968). Erstmals gab es in Japan und den USA Versuche einer Impfprophylaxe, in Deutschland wurden solche Bestrebungen jedoch noch nicht unterstützt.

Die letzte echte Grippepandemie des 20. Jahrhunderts war die sogenannte „Hongkong Grippe“ 1968-1970. Sie wurde von einem Erreger des Subtyps A/H3N2 ausgelöst. Ausgehend von Hongkong verbreitete sich das Virus im Sommer 1968 sehr schnell über Singapur, Taiwan, Malaysia und Vietnam. Im September traten die ersten Fälle in Indien auf, im Oktober in den USA und in Deutschland im Januar 1969. In Großbritannien fielen allein in einem Zeitraum von 8 Wochen 30000 Menschen der „Hongkong Grippe“ zum Opfer (Witte 2009, S.14). Im Rahmen dieser Pandemie wurde erstmals das kurz zuvor entwickelte Virustatikum Amantadin erfolgreich als Chemoprophylaktikum eingesetzt. Seine Wirksamkeit zur Behandlung des Parkinson-Syndroms fiel dabei rein zufällig auf.

In der Zusammenschau der in der Geschichte immer wieder auftretenden Grippepandemien lässt sich erkennen, dass die Influenza eine verheerende Seuche ist, gegen die therapeutische Bemühungen, allein aufgrund der großen Anzahl der Erkrankten, bisher oft wie ein “Tropfen auf den heißen Stein“ wirkten. Besonders die Beziehungen zwischen zoonotischem Auftreten und pandemischen Ausbrüchen ist weiterhin nicht voll verstanden und bedarf der intensiven Forschung. Eine sensitive PoC Diagnostik ist ein wichtiger Baustein, um eine gezielte antivirale Therapie der Influenza zu ermöglichen. Im 
Falle einer Pandemie sind jedoch Versuche, diese durch Früherkennung und hygienische Maßnahmen einzudämmen, aller Wahrscheinlichkeit nach zum Scheitern verurteilt.

\subsubsection{Die „Neue Grippe“ von 2009}

Im April 2009 traten in Mexiko und den USA erstmals Erkrankungen durch einen neuartigen Grippe-Erreger auf. Dieser wurde als Stamm A/California/04/2009(H1N1) typisiert. Er unterscheidet sich antigenetisch, d. h. die Virushülle betreffend, deutlich von der humanen, saisonalen Influenza. Die virale Oberfläche der „neuen Grippe“ ist nahezu identisch mit einem nordamerikanischen H1N1 Schweinegrippe-Stamm, der zuvor nur bei Tieren beobachtet wurde. Die neue Variante wird jedoch offenbar nur von Mensch zu Mensch übertragen (Garten et al. 2009). Es wird zurzeit davon ausgegangen, dass in Massentierhaltung gehaltene Schweine, die sich aufgrund ihrer Rezeptorausstattung gleichzeitig sowohl mit aviären, humanen als auch porcinen Influenzastämmen infizieren können, als eine Art Mischgefäß dienen und über diesen Mechanismus ein Reassortment und damit chimäre, humanpathogene Influenza Stämme erzeugt werden können (Medina und Garcia-Sastre 2011). Im Juni 2003 wurde bei 30000 Infizierten in 74 Ländern und 150 Todesopfern die „Neue Grippe“ von der WHO zur Pandemie erklärt. Durch die neuartige Oberfläche des Erregers bestand kein ausreichender Immunschutz in menschlichen Populationen. Die Erkrankung zeigte jedoch in der Regel einen milden Verlauf (Robert-Koch-Institut 2009a). Insgesamt forderte die „Neue Grippe“ deutlich weniger Todesopfer als die alljährliche saisonale Influenza, eine befürchtete Wiederholung der „Spanischen Grippe“ blieb aus, was auch zu einem Überdenken der Pandemiekriterien der WHO führte. Es kam jedoch, neben den erwarteten Komplikationen bei chronisch vorerkrankten Patienten, auch zu schweren und letalen Verläufen bei jüngeren (Vogel 2011, S.99f). 


\subsection{Orthomyxoviridae als Erreger viraler Atemwegsinfektionen}

\subsubsection{Influenza-A-Virus}

Das Influenza-A-Virus ist ein behülltes RNS-Virus aus der Familie der Orthomyxoviridae. Sein Genom besteht aus 8 Segmenten einzelsträngiger RNS in Negativstrangorientierung. Es kommt sowohl bei Menschen als auch bei Tieren, wie zum Beispiel Schweinen, Pferden, und diversen Vogelarten vor. Beim Menschen verursacht es hochansteckende Atemwegsinfektionen, bei Vögeln ist vor allem der Gastrointestinaltrakt betroffen. Aufgrund seiner Oberflächenantigene Haemagglutinin (HA) und Neuraminidase (NA) lässt sich das Influenza-A-Virus in verschiedene Subtypen unterteilen. Derzeit sind 16 HA Subtypen (H1-H16) und 9 NA Subtypen (N1-N9) bekannt. Davon sind die Varianten H1N1 und H3N2 Auslöser der humanen saisonalen Influenza, sie sind jedoch auch in Vogel- und Schweinepopulationen endemisch (Medina und Garcia-Sastre 2011). Die vollständige Nomenklatur setzt sich aus den Komponenten „A/Wirtsspezies/Land/Isolat/Jahr (HxNx)“ zusammen. Bei humanen Stämmen wird die Spezies nicht genannt. So wird beispielsweise der Auslöser der Influenzapandemie 2009, der in Kalifornien isoliert wurde, als „A/California/7/2009 (H1N1)“ bezeichnet (Fields et al. 2007, S.1691ff).

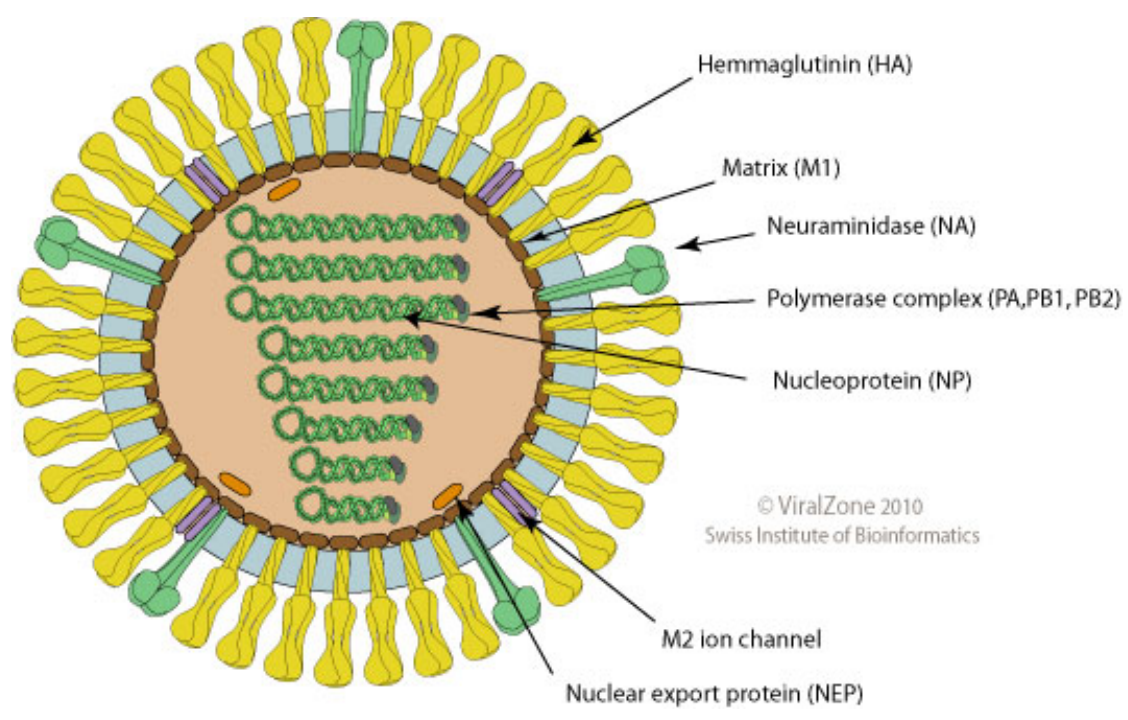

Abb. 1.1: $\quad$ Schematischer Aufbau des Influenza-A-Virus. Dargestellt ist ein behülltes Virion mit dem in 8 Segmenten quasizirkulär vorliegenden, einzelsträngigen RNS Genom, den Hüllproteinen Hämagglutinin (HA) und Neuraminidase (NA), dem Matrixprotein (M1), dem M2 Ionenkanal, dem Kern Export Protein (NEP) sowie dem Polymerasekomplex aus PA,PB1 und PB2. (SIB 2012) 
Die 8 einzelsträngigen Segmente der viralen RNS sind mit dem Nukleoprotein (NP) komplexiert und am 3'-Ende mit dem Polymerasekomplex aus PB1, PB2 und PA verbunden. Zusammen bilden sie die viralen Nukleokapside. Die 5'- und 3'-Enden der einzelnen Segmente sind komplementär. Sie bilden Doppelstränge und damit eine quasizirkuläre Form aus (Modrow 2010, S.357f). Die Innenseite der Hüllmembran ist von einer Proteinschicht aus dem Matrixprotein M1 bedeckt. Es interagiert während des Infektionsprozesses mit dem in die Membran eingelagerten M2 Ionenkanal, der durch Ansäuerung des Virusinneren eine Konformationsänderung bewirkt und den Fusionsprozess sowie den Transport der Nukleokapside zum Zellkern der Wirtszelle ermöglicht. Das Virostatikum Amantadin wirkt durch Beeinflussung dieser Prozesse am M2 Protein. Das an der Oberfläche des Virus lokalisierte Hämagglutinin (HA) bindet an N-Acetyl-Neuraminsäure (Sialinsäure) und ermöglicht so die Adhäsion und Fusion mit der Zielzelle. Dies ist jedoch nur möglich, wenn das inaktive Vorläufermolekül $\mathrm{HA}_{0}$ durch trypsinähnliche Proteasen in die Moleküle $\mathrm{HA}_{1}$ und $\mathrm{HA}_{2}$ gespalten wurde. Dieser Vorgang wird als wesentlicher Schritt für die Pathogenität des Virus angenommen. Die ebenfalls an der Virusoberfläche lokalisierte Neuraminidase dient dazu, die Neuraminsäurereste an der Oberfläche sowohl der infizierten Zellen als auch der neu gebildeten Viruspartikel zu entfernen. Erst dies ermöglicht eine Freisetzung neugebildeter Viren. Außerdem verhindert es eine Reinfektion bereits infizierter Zellen sowie ein Verkleben der Viruspartikel untereinander (Vergl. Modrow 2010, S.362). Die Virustatika der Gruppe der Neuraminidaseinhibitoren wirken durch Beeinflussung dieses Prozesses.

Der Wirtstropismus der einzelnen Subtypen der Influenza-A lässt sich durch die Rezeptorspezifität der einzelnen HA-Varianten erklären. Diese binden spezifisch an NAcetyl-Neuraminsäure-Reste, die als Modifikationen der Oberflächenstrukturen vieler Epithelien zu finden sind. An der Oberfläche des menschlichen respiratorischen Epithels ist die endständige Sialinsäure $\alpha(2,3)$-glycosidisch mit Galaktose verknüpft. Bei Vögeln dominiert eine $\alpha(2,6)$-glycosidische Bindung. Bei Schweinen kommen beide Verbindungen vor. Die unterschiedliche Affinität der einzelnen HA-Subtypen zu diesen Rezeptoren verhindert ein einfaches Übergreifen zoonotischer Influenza auf den Menschen. Das Schwein kann jedoch durch seine besondere Rezeptorausstattung als eine Art „Mischgefäß“ für unterschiedliche Virusvarianten betrachtet werden (Medina und Garcia-Sastre 2011). 
Die evolutionäre Anpassung des Influenzavirus an den Wirtsorganismus erfolgt über zwei Hauptmechanismen, welche als Antigen Drift und Antigen Shift bezeichnet werden. Unter Antigen Drift versteht man die graduelle Veränderung des viralen Genoms durch spontane Punktmutationen, welche einen Vorteil gegen neutralisierende Antikörper bieten und daher selektiert werden. Dieser Vorgang wird besonders mit der Varianz der saisonalen Influenza in Verbindung gebracht. Antigen Drift Varianten überdauern typischerweise einen Zeitraum von 2-5 Jahren, bis sie von einer neuen Variante verdrängt werden (Fields et al. 2007, S.1701). Als Antigen Shift bezeichnet man sprunghafte Antigenveränderungen, die durch eine Durchmischung von Nukleinsäuresegmenten verschiedener Subtypen entstehen können. Dies ist möglich, wenn sich ein Wirtsorganismus (in der Regel Schweine) gleichzeitig mit mehreren Influenza Subtypen infiziert. So sind die Pandemien von 1957 (H2N2) und 1968 (H3N2) durch eine Vermischung humaner und aviärer Influenzastämme ausgelöst worden. Nach dem Überspringen der Spezies-Barriere konnte die damalige, immunologisch naive, menschliche Population dem neuen Virus wenig entgegensetzen (Medina und GarciaSastre 2011).

\subsubsection{Influenza-B-Virus}

Das Influenza-B-Virus zeigt als enger Verwandter des Influenza-A-Virus und Mitglied der Familie der Orthomyxoviridae einen vergleichbaren Aufbau. Es ist ebenfalls ein behülltes RNS-Virus dessen Genom in 8 einzelsträngigen Segmenten in Negativstrangorientierung vorliegt. Es wurde jedoch nur bei Menschen und Robben nachgewiesen. Dort ruft es das gleiche Krankheitsspektrum wie Influenza-A hervor, die Erkrankungen verlaufen jedoch in der Regel etwas milder. Ein pandemisches Auftreten ist nicht beschrieben. Im Vergleich ist bei Influenza-B-Patienten etwa viermal seltener eine Krankenhauseinweisung nötig. Myositis, Reye Syndrom und gastrointestinale Beschwerden treten dort jedoch häufiger als bei Influenza-A auf (Fields et al. 2007, S.1722). Beim Influenza-B-Virus sind keine HA und NA Subtypen bekannt. Es zirkulieren jedoch mit den Linien B/Victoria und B/Yamagata zwei unterschiedliche Varianten. 


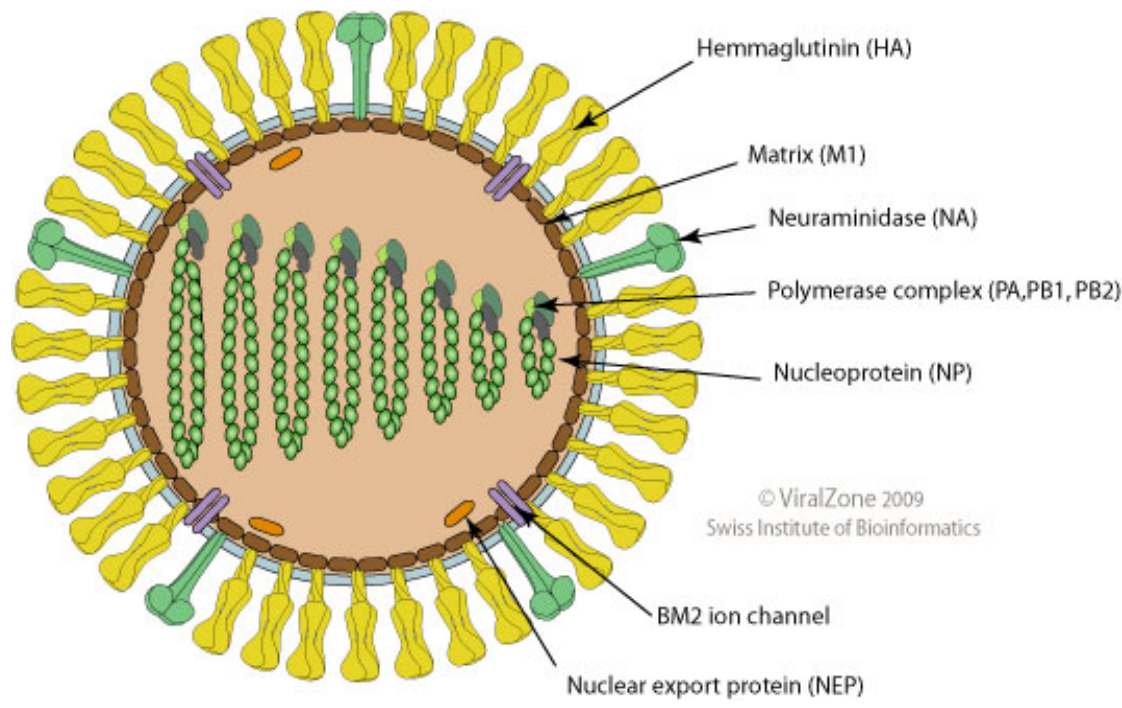

Abb. 1.2: $\quad$ Schematischer Aufbau des Influenza-B-Virus. Dargestellt ist ein behülltes Virion mit dem in 8 Segmenten quasizirkulär vorliegenden, einzelsträngigen RNS Genom, den Hüllproteinen Hämagglutinin (HA) und Neuraminidase (NA), dem Matrixprotein (M1), dem M2 Ionenkanal, dem Kern Export Protein (NEP) sowie dem Polymerasekomplex aus PA,PB1 und PB2. (SIB 2012)

\subsection{Humane Adenoviridae als Erreger viraler Atemwegsinfektionen}

Humane Adenoviren (HAdV) sind unbehüllte DNS-Viren der Gattung Mastadenovirus aus der Familie der Adenoviridae. Das virale Genom liegt als linearer Doppelstrang vor. Die sieben humanpathogenen Spezies A-G werden in 57 unterschiedliche Serotypen eingeteilt. Sie können unterschiedlichste Erkrankungen aller Organsysteme verursachen. Neben influenzaartigen Symptomen können Pharyngitis, Pneumonien und pertussisartige Erkrankungen vorkommen. Des Weiteren können humane Adenoviren Ursache von Hepatitis, Gastroenteritis, heamorrhagischer Zystitis und der epidemischen Keratokonjunktivitis sein (Echavarria et al. 1999).

Die viralen Kapside sind in Form eines Ikosaeder aufgebaut und jeweils aus 240 sogenannten Hexonen (Protein II) und 12 Pentonen zusammengesetzt. Jede Pentonbasis (Protein III) ist mit einem hervorstehenden sogenannten Fiberprotein (Protein IV) assoziiert. Variationen der drei Kapsidproteine Hexon, Pentonbasis und Fiberprotein stellen die klinisch relevanten Epitope zur Differenzierung der verschiedenen Spezies und Serotypen dar. Der im Inneren des Partikels befindliche Nukleoproteinkomplex besteht aus dem viralen Genom sowie den Proteinen pV, pVII und $\mu$. Die viralen Strukturproteine 
werden nach ihrer Laufgeschwindigkeit in der Gel-Elektrophorese nummeriert (Modrow 2010, S.521f).

Akute respiratorische Erkrankungen werden bei Kindern häufig von den Serotypen HAdV-1, -2 und -5 (Spezies HAdV-C) ausgelöst. Lebensbedrohliche Pneumonien bei jungen Erwachsenen sind mit den Serotypen HAdV-4 (Spezies HAdV-E) und HAdV-7 (Spezies-HAdV-B) assoziiert. Diese können auch, ebenso wie HAdV-3 (Spezies HAdVB), Auslöser des Pharyngokonjunktivalfiebers sein (Heim et al. 2003). Ein Schnelltest zur Differenzierung viraler Atemwegserkrankungen sollte daher insbesondere in der Lage sein, die Spezies B, C und E nachzuweisen.
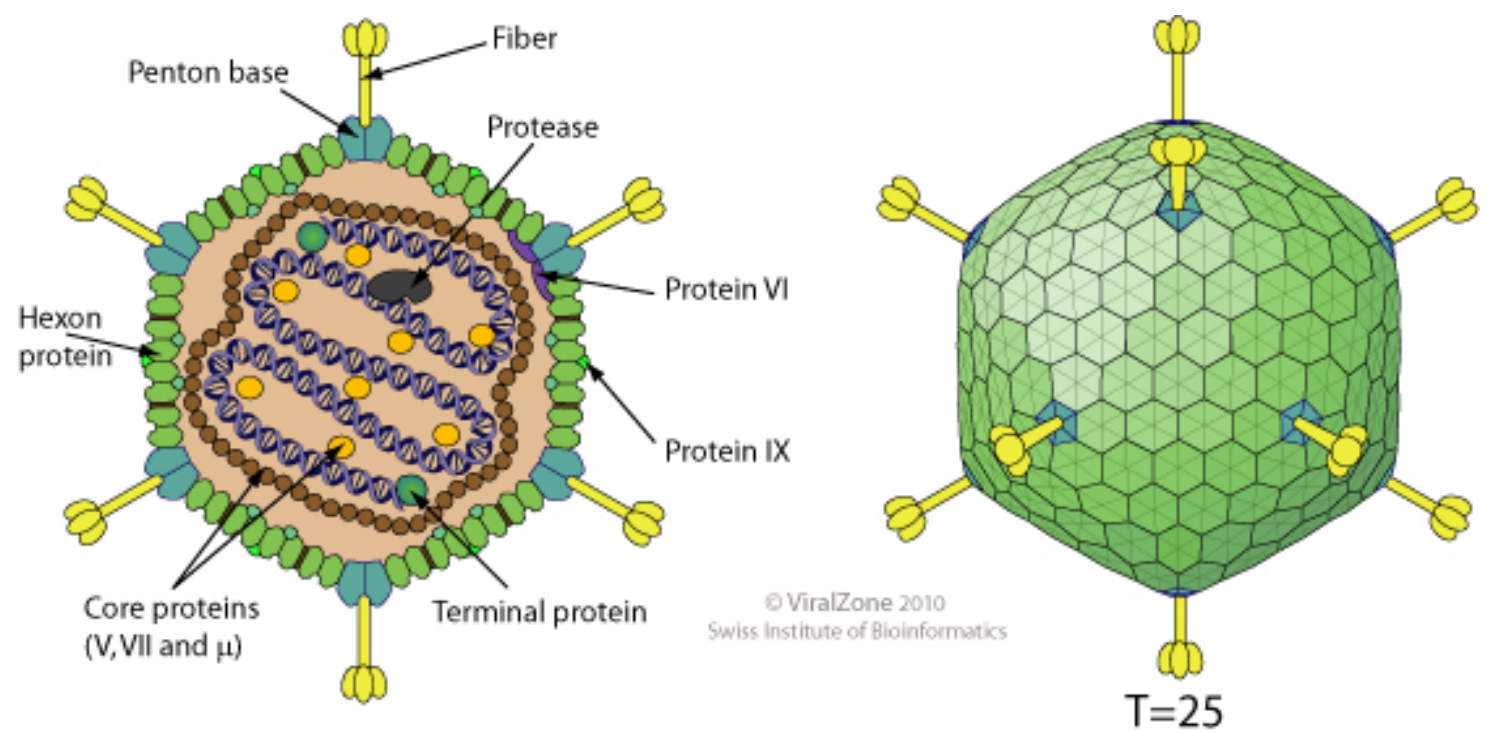

Abb. 1.3:

Schematischer Aufbau humaner Adenoviren. Dargestellt ist ein Virion mit ikosaedrischem Kapsid bestehend aus den Kapsdiproteinen Hexon, Pentonbasis und Penton. Im Inneren des Kapsids befinden sich der Nukleoproteinkomplex aus dem doppelsträngigen DNS Genom und den Proteinen pV,PVII und $\mu$. (SIB 2012)

\subsection{Nachweis viraler Atemwegserreger}

Zum Nachweis einer bestehenden oder abgelaufenen Virusinfektion gibt es verschiedene Strategien. Zum einen lassen sich im Falle einer akuten Infektion die Erreger direkt in Patientenmaterial nachweisen, andererseits kann auch der serologische Nachweis der aus der Infektion resultierenden Immunreaktion in Form von Antikörpern auf eine bestehende oder abgelaufene Infektion hinweisen. Da im Falle akuter Atemwegsinfektionen eine 
möglichst schnelle Diagnostik nötig und eine entsprechende Immunantwort bei Symptombeginn oft noch nicht ausgeprägt ist, finden hier, anders als bei vielen anderen viralen Erkrankungen, eher direkte Nachweisverfahren Anwendung. Als klassisches Verfahren zur Vermehrung von Viren gilt die Anzucht in embryonierten Hühnereiern oder Zellkulturen. Die aufwendige Anzucht in Hühnereiern wird jedoch in der Regel nur noch zur Kultivierung von Referenzstämmen bei der Impfstoffherstellung verwendet. Aufgrund der einfacheren Handhabung werden anstelle von Hünereiern oft immortalisierte Zelllinien (z.B. MDCK-Zellen) verwendet, in denen sich mehrere Tage nach Infektion lichtmikroskopisch Veränderungen der Zellstruktur und ein zytopathischer Effekt als Zeichen der Virusvermehrung erkennen lassen. Da dieses Verfahren jedoch zeitaufwendig und nicht spezifisch ist, findet es hauptsächlich in der Forschung Anwendung und spielt im klinischen Alltag eine untergeordnete Rolle (Schweiger 2009, S.68f). Eine höhere Spezifität erzielen Verfahren wie direkte Immunfluoreszenz oder Antigen-ELISAs, die mittels monoklonaler Antikörper Bestandteile der Erreger nachweisen. Den höchsten Stellenwert für die Diagnostik haben heutzutage, aufgrund ihrer hohen Sensitivität, jedoch Systeme, die virale Nukleinsäuremoleküle direkt in Patientenmaterial nachweisen (Modrow 2010, S.380).

\subsubsection{Nukleinsäure-Nachweisverfahren (NAAT)}

Aufgrund ihrer hohen Spezifität und Sensitivität sowie der relativ unkomplizierten Anwendung werden im klinisch diagnostischen Alltag in der Regel auf der Polymerasekettenreaktion (PCR) basierende Nukleinsäure-Nachweisverfahren verwendet. Dabei findet besonders die Echt-Zeit-PCR (engl. Real-time PCR) Verwendung, die mithilfe einer Fluoreszenzsonde den Amplifikationsprozess in Echtzeit misst. Im Falle des Nachweises viraler RNS wird der PCR-Reaktion zunächst ein Reverse-Transkriptase Schritt vorangestellt, um cDNS zu erzeugen. Dann werden in vielfach wiederkehrenden Zyklen DNS-Doppelstränge thermisch denaturiert, spezifische Oligonukleotide angelagert und mithilfe von thermostabiler Polymerase ein komplementärer Gegenstrang generiert. Durch die 5'->3'-Exonukleaseaktivität der Polymerase werden Fluophor und Quencher einer spezifisch bindenden Sonde separiert und die Amplifikationsreaktion kann in Form zunehmender Fluoreszenz in Echtzeit gemessen werden. Dieses Verfahren erfordert jedoch einen gewissen apparativen Aufwand, verbraucht viel Energie und dauert einige 
Stunden. Das bedeutet für den niedergelassenen Arzt, dass er Patientenmaterial an ein spezialisiertes Labor einschicken muss und das Ergebnis in der Regel erst am nächsten Tag erhält.

\subsubsection{Bestehende Point-of-Care-Testverfahren}

Die am Markt erhältlichen Influenza Schnelltests, die in der Arztpraxis in 15-20 Minuten durchgeführt werden können, basieren auf enzymgekoppelten Immunessays, welche virale Proteine nachweisen. Mit ihrer Hilfe lässt sich in Nasen- oder Rachenabstrichen das Nukleoprotein von Influenza-A und -B Viren nachweisen, weitere relevante Differentialdiagnosen werden jedoch in der Regel nicht mit abgedeckt. Da der Nachweis auf Proteinebene ansetzt und stark abhängig von der Qualität des gewonnenen Abstrichmaterials ist, erreichen heutige Schnelltests eine deutlich geringere Sensitivität als Nukleinsäure-Nachweisverfahren. Die Angaben zur Sensitivität schwanken zwischen unterschiedlichen Studien stark, sie wird teilweise mit nur 60\% angegeben (Walsh et al. 2002). So kann bei einem negativen Testergebnis eine Influenzainfektion derzeit nicht ausgeschlossen werden, so dass zur Diagnosesicherung meist auf den zeitaufwendigeren genomischen Nachweis mittels Echtzeit-RT-PCR durch ein externes Labor zurückgegriffen werden muss. Aufgrund dieser Schwäche kommen Point-of-Care-Tests in Deutschland nicht überall routinemäßig zum Einsatz. Die entstehenden Kosten werden von den gesetzlichen Krankenkassen in der Regel nicht übernommen.

Gerade im Fall der Influenza ließe sich durch eine sichere Point-of-Care-Diagnostik eine frühzeitige virustatische Therapie sicherstellen. Es konnte gezeigt werden, dass Influenza Schnelltests durch diesen Vorteil im Falle eines positive Testergebnisses dazu beitragen, Antibiotika einzusparen (Falsey et al. 2007) und die Dauer von Krankenhausaufenthalten zu verkürzen (Barenfanger et al. 2000). Erfolgt die Diagnostik jedoch später, hat sie bereits 12-36 Stunden nach der ersten Arztkonsultation keinen nachweisbaren Einfluss auf Krankenhauseinweisungen, Antibiotikaverbrauch und Krankheitsverlauf (Wishaupt et al. 2011). 


\subsection{Rekombinase-Polymerase-Amplifikation (RPA)}

Auf der Polymerase-Kettenreaktion (PCR) basierende Amplifikationsverfahren stellen den Goldstandard für den Nachweis spezifischer DNS-Sequenzen dar. Sie sind jedoch aufgrund der benötigten Thermocycler aufwendig und auf eine Laborumgebung beschränkt. Das von Piepenburg und Armes entwickelte Verfahren der RPA bietet einen alternativen Ansatz zur exponentiellen Vervielfältigung von DNS (Piepenburg und Armes 2007). Es arbeitet bei konstanten niedrigen Temperaturen von $24-45^{\circ} \mathrm{C}$ ohne eine besondere Vorbehandlung oder thermische Denaturierung der Probe. Seine Sensitivität ist mit unter 10 Kopien Zielmolekül der PCR ebenbürtig. Mit nur 20 Minuten Reaktionszeit ist es wesentlich schneller als alternative Verfahren. Besonders die einfache Detektion des Amplifikationsprozesses mittels Fluoreszenzsonden und der sehr schnelle Ablauf der Reaktion machen es zu einem interessanten Verfahren für den Einsatz am Patientenbett, in Arztpraxen und in Entwicklungsländern.

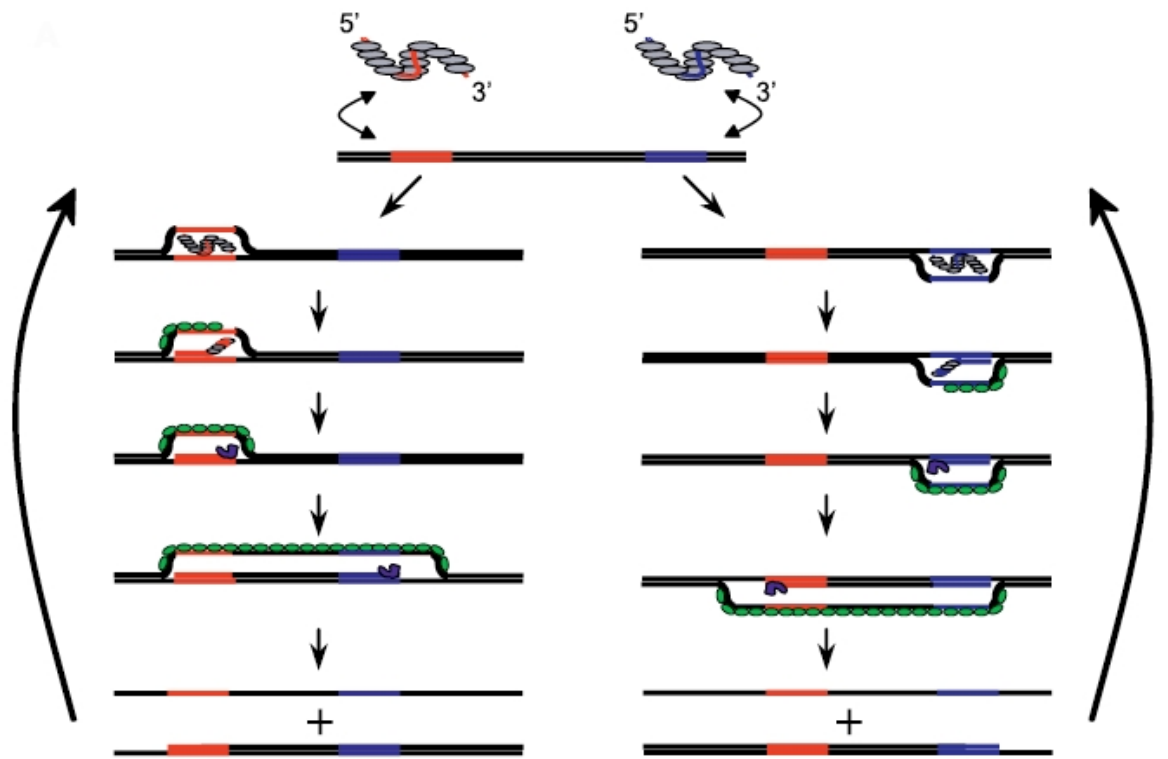

Abbildung nach: Piepenburg O, et al. 2006

Abb. 1.4: Schematischer Ablauf der Rekombinase-Polymerase-Amplifikation. Dargestellt ist die sogenannte Stranginvasion durch Rekombinase-Oligonukleotid-Komplexe (Grau), die Hybridisierung des Oligonukleotids an die Zielsequenz (Rot und Violett), die Stabilisierung der resultierenden Struktur durch gp32 (Grün) und die strangverdrängende, semikonservative Replikation der Ziel-DNS. 
Wie die PCR basiert RPA auf der Anlagerung komplementärer Oligonukleotidprimer an die Ziel-DNS und deren Elongation durch DNS-Polymerase. Dies führt zu einer semikonservativen Verdopplung der Zielsequenz. Bei der RPA wird jedoch der DNA Doppelstrang nicht durch Erhitzen aufgebrochen. Das Enzym Recombinase (T4 UvsX) (Grau) interagiert mit den Oligonukleotiden und paart diese mit homologen Sequenzen der doppelsträngigen Ziel-DNS (Rot und Violett). Unterstützt wird dieser Vorgang durch den Kofaktor UvsY. Dieser als Stranginvasion bezeichnete Prozess erfolgt ATPabhängig. Die resultierende Struktur wird durch T4-gp32-einzelsträngige-DNSBindeprotein (Grün) stabilisiert. Die gebundenen Oligonukleotide werden in 5'-3'Richtung durch eine strangverdrängende Sau- (Staphylococcus aureus) Polymerase entsprechend dem Zielmolekül verlängert. Die Wiederholung dieses Vorganges führt zur exponentiellen Vervielfältigung der Zielregion (Piepenburg et al. 2006).

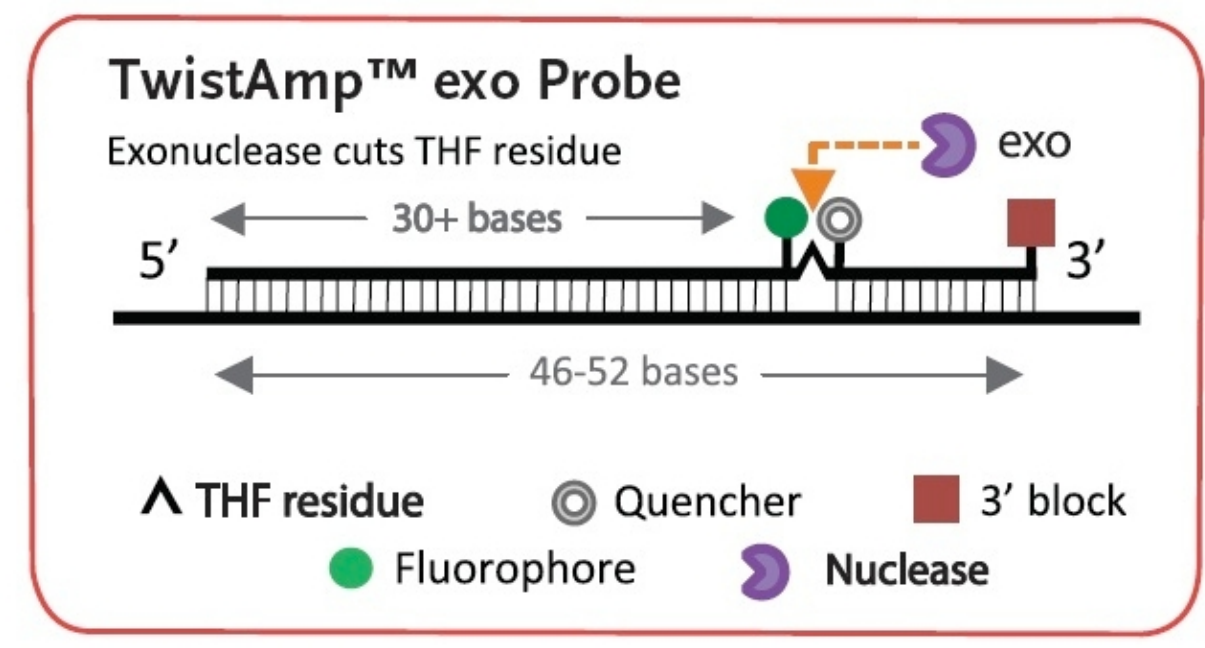

Abb. 1.5: Schematische Darstellung einer TwistAmp ${ }^{\mathrm{TM}}$ exo-Sonde. Dargestellt ist eine hybridisierte exo-Sonde mit dem durch Fuoreszenzfarbstoff und Quencher eingerahmten Tetrahydrofuran-Platzhalter, eine Phosphatgruppe am 3'-Ende der Sonde sowie das DNSReparaturenzym Exonuclease III. (Quelle: TwistAmp ${ }^{\mathrm{TM}}$ exo RPA Kit Manual.)

Um diesen Amplifikationsprozess in Echtzeit zu verfolgen, kann ein als TwistAmp ${ }^{\circledR}$ exo bezeichnetes Fluoreszenzsondensystem eingesetzt werden. Dieses ist schematisch in Abb. 1.5 dargestellt. Die Sonde bindet spezifisch an einen Abschnitt der Zielregion zwischen den Hybridisierungsstellen der Oligonucleotide. Sie bestehen aus einem längeren 5'-Arm und einem kurzen 3'-Arm. Diese sind durch einen sogenannten TetrahydrofuranPlatzhalter (THF) verbunden. In direkter Nachbarschaft dieses Platzhalters sind ein 
Fluoreszenzfarbstoff und ein Quencher kovalent an die Segmente der Sonde gebunden. Nur im Falle einer Bindung der Sonde an einen korrespondierenden Gegenstrang, welcher dem nachzuweisenden Zielmolekül entspricht, wird die durch den Platzhalter erzeugte AP-Stelle durch das DNS-Reparaturenzym Exonuclease III geschnitten. Das kurze 3'Ende der Sonde löst sich vom Zielmolekül, Fluoreszenzfarbstoff und Quencher werden getrennt und eine Zunahme der Fluoreszenz kann mit wenig technischem Aufwand gemessen werden. (Vergleiche: TwistAmp ${ }^{\mathrm{TM}}$ Reagenziensatz Anleitung)

\subsection{Zielsetzung und Fragestellung}

Ziel dieser Arbeit war die Entwicklung von isothermalen molekularen Amplifikationsverfahren zum Nachweis von Influenza-A-Virus, Influenza-B-Virus und differentialdiagnostisch relevanten humanen Adenoviren.

$\Rightarrow$ Hierzu sollten spezifische Primer und Sonden für Rekombinase-PolymeraseAmplifikations-Nachweisverfahren für das Influenza-A-Virus, Influenza-B-Virus und respiratorische Adenoviren entworfen werden.

$\Rightarrow$ Zur Austestung der analytischen Sensitivität und Spezifität sollten jeweils synthetische quantitative molekulare Standards hergestellt werden.

$\Rightarrow$ Die analytische Sensitivität der Verfahren sollte anhand einer Probit-Analyse verifiziert werden.

$\Rightarrow$ Die analytische Spezifität sollte durch Kreuztestungen gezeigt werden. 


\section{Material und Methoden}

\subsection{Material}

\subsubsection{Verbrauchsmaterialien und Geräte}

Tabelle 2.1 Verwendete Verbrauchsmaterialen und Geräte

\begin{tabular}{|c|c|}
\hline Verbrauchsmaterial & Bezugsquelle \\
\hline Falcon-Röhrchen (15ml, 50ml) & Sarstedt AG \& Co, Nümbrecht, Deutschland \\
\hline $\begin{array}{l}\text { Gewebekulturschalen } \\
(100 x 20 \mathrm{~mm})\end{array}$ & $\begin{array}{l}\text { Greiner Bio-One GmbH, Frickenhausen, } \\
\text { Deutschland }\end{array}$ \\
\hline Handschuhe (Latex) & Mikroflex Corporation, Vienna, Österreich \\
\hline Handschuhe (Nitril) & GE Healthcare Europe NV, Brüssel, Belgien \\
\hline Labortücher 20,5cmx20cm & Kimberly-Clark Europe Limited, Kings Hill, UK \\
\hline Light Cycler®Capillaries $(20 \mu \mathrm{l})$ & Roche Diagnostics GmbH, Mannheim, Deutschland \\
\hline $\begin{array}{l}\text { Microplatte } \\
\text { Boden/Kaminform (96-K) } \\
\text { FLUOTRAC }\end{array}$ & $\begin{array}{l}\text { Greiner Bio-One GmbH, Frickenhausen, } \\
\text { Deutschland }\end{array}$ \\
\hline $\begin{array}{l}\text { Microplatte U-Form (96-K) } \\
\text { MICROLON® } 200\end{array}$ & $\begin{array}{l}\text { Greiner Bio-One GmbH, Frickenhausen, } \\
\text { Deutschland }\end{array}$ \\
\hline Parafilm & American National Can, Chicago, USA \\
\hline PCR-Reaktionsgefäße $(0,2 \mathrm{ml})$ & Biozym, Scientific GmbH, Oldendorf Deutschland \\
\hline $\begin{array}{l}\text { Pipettenspitzen mit Filter } \\
(0,1-10 \mu \mathrm{l}, \quad 1,0-100 \mu \mathrm{l}, \quad 101- \\
1000 \mu \mathrm{l})\end{array}$ & Starlab GmbH, Ahrensberg, Deutschland \\
\hline $\begin{array}{l}\text { Pipettenspitzen ohne Filter }(0,1- \\
10 \mu \mathrm{l}, 1,0-100 \mu \mathrm{l}, 101-1000 \mu \mathrm{l})\end{array}$ & Starlab GmbH, Ahrensberg, Deutschland \\
\hline $\begin{array}{l}\text { Safe-Lock-Tubes }(0,5 \mathrm{ml}, 1,5 \mathrm{ml} \text {, } \\
\text { 2ml) }\end{array}$ & Eppendorf AG, Hamburg, Deutschland \\
\hline $\begin{array}{l}\text { Vernichtungsbeutel } \\
\text { (300mmx200mm) }\end{array}$ & $\begin{array}{l}\text { Lab Logistic Group GmbH, Meckenheim, } \\
\text { Deutschland }\end{array}$ \\
\hline
\end{tabular}


Tabelle 2.2 Verwendete Geräte

\begin{tabular}{|c|c|}
\hline Geräte & Bezugsquelle \\
\hline Bakterienbrutschrank & $\begin{array}{l}\text { Heraeus Instruments GmbH, Hannover, } \\
\text { Deutschland }\end{array}$ \\
\hline Chemidoc XRS System & $\begin{array}{l}\text { Bio Rad Laboratories GmbH, München, } \\
\text { Deutschland }\end{array}$ \\
\hline $\begin{array}{l}\text { FLUOstar Optima Microplate } \\
\text { Fluorometer }\end{array}$ & BMG Labtech GmbH, Cary, USA \\
\hline $\begin{array}{l}\text { Elektrophoresekammern } \\
\text { HORIZON } 58 \\
\text { HORIZON } 1114\end{array}$ & Life Technologies Inc., Maryland, USA \\
\hline Elektrophoresis Power Supply & Amersham Biosciences, Chandler, USA \\
\hline Gefrierschrank $\left(-20^{\circ} \mathrm{C}\right)$ & Liebherr GmbH, Ochsenhausen, Deutschland \\
\hline Gefrierschrank $\left(-80^{\circ} \mathrm{C}\right)$ & Thermo Scientific, Rockford, USA \\
\hline Gelelektrophoresekammer & Invitrogen Corporation, Kalifornien, USA \\
\hline Heizblock (Thermomixer) & Eppendorf AG, Hamburg, Deutschland \\
\hline Kühlschrank $\left(5^{\circ} \mathrm{C}\right)$ & Liebherr GmbH, Ochsenhausen, Deutschland \\
\hline Light Cycler ${ }^{\circledR} 2.0$ & Roche Diagnostics GmbH, Mannheim, Deutschland \\
\hline $\begin{array}{l}\text { Nano Drop }{ }^{\circledR} \quad \text { ND-1000 } \\
\text { Spektralphotometer }\end{array}$ & Thermo Scientific, Rockford, USA \\
\hline Thermocycler & Biometra GmbH, Göttingen, Deutschland \\
\hline Vortexer & $\begin{array}{l}\text { Bender\&Hobein AG, Zürich, Schweiz } \\
\text { Scientific Industries Inc, New York, USA }\end{array}$ \\
\hline Tube Scanner & $\begin{array}{l}\text { Qiagen Lake Constance GmbH, Stockach, } \\
\text { Deutschland }\end{array}$ \\
\hline Zentrifuge & Eppendorf AG, Hamburg, Deutschland \\
\hline $\begin{array}{l}\text { Zenrifuge } \quad \text { (LC-Carousel } \\
\text { Centrifuge) }\end{array}$ & Roche Diagnostics GmbH, Mannheim, Deutschland \\
\hline Zentrifuge (Megafuge 1.0R) & Thermo Scientific, Rockford, USA \\
\hline Zentrifuge (Mini) & LMS Co. LTD, Tokyo, Japan \\
\hline
\end{tabular}




\subsubsection{Chemikalien}

Tabelle 2.3 Verwendete Chemikalien

\begin{tabular}{|c|c|}
\hline Chemikalien & Bezugsquelle \\
\hline Agarose & $\begin{array}{l}\text { Biozym Scientific GmbH, Oldendorf, } \\
\text { Deutschland }\end{array}$ \\
\hline Acetamid & $\begin{array}{l}\text { Sigma-Aldrich Chemie GmbH, Steinheim, } \\
\text { Deutschland }\end{array}$ \\
\hline Ampicillin & $\begin{array}{l}\text { Roche Diagnostics GmbH, Mannheim, } \\
\text { Deutschland }\end{array}$ \\
\hline BSA (10mg/ml) & New England Biolabs Inc., Ipswich, England \\
\hline $\begin{array}{l}\text { Desoxyribonukleosidtriphosphate } \\
\text { (dNTP) }\end{array}$ & Fermentas GmbH, Leon-Rot, Deutschland \\
\hline Dithiothreitol (DTT 0,1M) & GE Healthcare Europe NV, Brüssel, Belgien \\
\hline Ethanol & Merck KG aA, Darmstadt, Deutschland \\
\hline Ethidiumbromid & $\begin{array}{l}\text { Carl Roth GmbH + Co. KG, Karlsruhe, } \\
\text { Deutschland }\end{array}$ \\
\hline Glycerin & $\begin{array}{l}\text { Carl Roth GmbH + Co. KG, Karlsruhe, } \\
\text { Deutschland }\end{array}$ \\
\hline Orange Loading Dye (6x) & Fermentas GmbH, Leon-Rot, Deutschland \\
\hline $\begin{array}{l}\text { DNS LängenStandards: O’Gene } \\
\text { Ruler }^{\mathrm{TM}} \text { 100bp DNA Ladder Plus; } \\
\text { O’Gene Ruler }{ }^{\mathrm{TM}} \text { 1bkb DNA Ladder; } \\
\text { 1kb DNA Ladder Plus }\end{array}$ & Fermentas GmbH, Leon-Rot, Deutschland \\
\hline Ribonukleosidtriphosphate (rNTPs) & $\begin{array}{l}\text { Roche Diagnostics GmbH, Mannheim, } \\
\text { Deutschland }\end{array}$ \\
\hline Tetramethylammoniumchlorid (5M) & $\begin{array}{l}\text { Sigma-Aldrich Chemie GmbH, Steinheim, } \\
\text { Deutschland }\end{array}$ \\
\hline $\begin{array}{l}\text { Ribonukleinsäure aus S. cerevisiae } \\
\text { (tRNS) }\end{array}$ & $\begin{array}{l}\text { Sigma-Aldrich Chemie GmbH, Steinheim, } \\
\text { Deutschland }\end{array}$ \\
\hline X-Gal & $\begin{array}{l}\text { Carl Roth GmbH + Co. KG, Karlsruhe, } \\
\text { Deutschland }\end{array}$ \\
\hline
\end{tabular}




\subsubsection{Lösungen, Medien und Puffer}

Tabelle 2.4 Verwendete Lösungen, Medien und Puffer

\begin{tabular}{|c|c|}
\hline Name & Zusammensetzung \\
\hline Agarosegel [1\%ig] & $\begin{array}{l}\text { 100ml TAE }[1 \mathrm{x}], \quad 1 \mathrm{~g} \text { Agarose, } 5 \mu \mathrm{l} \\
\text { Ehtidiumbromid- Lösung (Endkonzentration } \\
0,5 \mathrm{mg} / \mathrm{ml} \text { ) }\end{array}$ \\
\hline Ethidiumbromid-Lösung & $10 \mathrm{mg} / \mathrm{ml}$ in $\mathrm{H}_{2} \mathrm{O}$ \\
\hline LB (Luria Bertani)-Amp-Agar & $\begin{array}{l}10 \mathrm{~g} \text { Bacto }^{\mathrm{TM}} \text {-Tryptone, } 5 \mathrm{~g} \text { Bacto }^{\mathrm{TM}} \text {-Yeast } \\
\text { Extract, } 10 \mathrm{~g} \text { Nacl, } 1 \mathrm{ml} \text { Ampicilin[100 } \mu \mathrm{g} / \mathrm{ml}], 15 \\
\text { g Bacto }^{\mathrm{TM}} \text {-Agar, ad } 1 \mathrm{l} \mathrm{H}_{2} \mathrm{O}\end{array}$ \\
\hline LB-Amp-Medium & $\begin{array}{l}10 \mathrm{~g} \text { Bacto }^{\mathrm{TM}} \text {-Tryptone, } 5 \mathrm{~g} \text { Bacto }^{\mathrm{TM}} \text {-Yeast } \\
\text { Extract, } 10 \mathrm{~g} \text { Nacl, } 1 \mathrm{ml} \text { Ampicilin[100 } \mu \mathrm{g} / \mathrm{ml}] \text {, ad } \\
1 \mathrm{l} \mathrm{H}_{2} \mathrm{O}\end{array}$ \\
\hline S.O.C.-Medium & Invitrogen GmbH, Karlsruhe, Deutschland \\
\hline TAE $[1 \mathrm{x}]$ & 40ml TAE [50x] ad $1960 \mathrm{ml} \mathrm{H}_{2} \mathrm{O}$ \\
\hline TAE $[50 x]$ & $\begin{array}{l}\text { 242g Tris: 57,1ml Essigsäure, 100ml EDTA } \\
\text { pH8,0 }[0,5 \mathrm{M}]\end{array}$ \\
\hline TE-Puffer & 10mM Tris (pH 8,0), 1mM EDTA \\
\hline
\end{tabular}

\subsubsection{Reagenziensätze}

Tabelle 2.5 Verwendete Reagenzienansätze

\begin{tabular}{|c|c|}
\hline Name & Bezugsquelle \\
\hline Ambion Turbo DNA-free ${ }^{\mathrm{TM}}$-Kit & Applied Biosystems, Darmstadt, Germany \\
\hline $\begin{array}{l}\text { Dual Promotor TA Cloning }{ }^{\circledR} \text { Kit } \\
\text { (with pCRII }{ }^{\circledR}-\text { Vektor) with one } \\
\text { Shot }{ }^{\circledR} \quad \text { INV } \alpha \text { F' Chemically } \\
\text { Competent E.coli }\end{array}$ & Invitrogen GmbH, Karlsruhe, Deutschland \\
\hline $\begin{array}{l}\text { Light Cycler }{ }^{\circledR} 480 \text { RNA Master } \\
\text { Hydrolysis Probes }\end{array}$ & $\begin{array}{l}\text { Roche Diagnostics GmbH, Mannheim, } \\
\text { Deutschland }\end{array}$ \\
\hline $\begin{array}{l}\text { Light } \text { Cycler }{ }^{\circledR} \text { Fast start DNA } \\
\text { Master HybProbe }\end{array}$ & $\begin{array}{l}\text { Roche Diagnostics GmbH, Mannheim, } \\
\text { Deutschland }\end{array}$ \\
\hline
\end{tabular}




\begin{tabular}{|c|c|}
\hline PeqGOLD Plasmid Miniprep Kit I & $\begin{array}{l}\text { Peqlab Biotechnologie GmbH, Erlangen, } \\
\text { Deutschland }\end{array}$ \\
\hline $\begin{array}{l}\text { Quantum Prep }{ }^{\mathrm{TM}} \text { Plasmid Midiprep } \\
\text { Kit }\end{array}$ & Bio-Rad Laboratories, Hercules (CA), USA \\
\hline TwistAmp ${ }^{\mathrm{TM}}$ exo Kit & TwistDx, Cambridge, UK \\
\hline $\begin{array}{l}\text { Quant-iT }{ }^{\mathrm{TM}} \text { PicoGreen }{ }^{\circledR} \text { dsDNA } \\
\text { Assay Kit }\end{array}$ & Invitrogen GmbH, Karlsruhe, Deutschland \\
\hline $\begin{array}{l}\text { Quant-iT }{ }^{\mathrm{TM}} \quad \text { RiboGreen }{ }^{\circledR} \quad \text { RNA } \\
\text { Assay Kit }\end{array}$ & Invitrogen GmbH, Karlsruhe, Deutschland \\
\hline $\begin{array}{l}\text { Quantum Prep }{ }^{\mathrm{TM}} \text { Plasmid Midiprep } \\
\text { Kit }\end{array}$ & $\begin{array}{l}\text { Bio Rad Laboratories GmbH, München, } \\
\text { Deutschland }\end{array}$ \\
\hline $\begin{array}{l}\text { Zymoclean }^{\mathrm{TM}} \text { Gel DNA Recovery } \\
\text { Kit }\end{array}$ & Zymo Research, Freiburg, Deutschland \\
\hline $\begin{array}{l}\text { Zymoresearch }^{\mathrm{TM}} \text { DNA Clean \& } \\
\text { Concentrator-5 }\end{array}$ & Zymo Research, Freiburg, Deutschland \\
\hline
\end{tabular}

\subsubsection{Enzyme}

Tabelle 2.6 Verwendete Enzyme

\begin{tabular}{|c|c|}
\hline Name & Bezugsquelle \\
\hline Taq-DNA-Polymerase & 5-Prime GmbH, Hamburg, Deutschland \\
\hline $\begin{array}{l}\text { PowerScript Long DNA } \\
\text { Polymerase }\end{array}$ & Pan Biotech GmbH, Aidenbach, Deutschland \\
\hline Fast Digest ${ }^{\circledR}$ EcoRI & Fermentas GmbH, Leon-Rot, Deutschland \\
\hline Fast Digest ${ }^{\circledR}$ PdmI (XmnI) & Fermentas GmbH, Leon-Rot, Deutschland \\
\hline Fast Digest ${ }^{\circledR}$ HindIII & Fermentas GmbH, Leon-Rot, Deutschland \\
\hline Protector RNase Inhibitor & $\begin{array}{l}\text { Roche Diagnostics GmbH, Mannheim, } \\
\text { Deutschland }\end{array}$ \\
\hline $\begin{array}{l}\text { SP6 RNA Polymerase from } \\
\text { Escherichia coli BL 21/pSR3 }\end{array}$ & $\begin{array}{l}\text { Roche Diagnostics GmbH, Mannheim, } \\
\text { Deutschland }\end{array}$ \\
\hline $\begin{array}{l}\text { T7 RNA Polymerase from } \\
\text { Escherichia coli BL 21/pAR } 1219\end{array}$ & $\begin{array}{l}\text { Roche Diagnostics GmbH, Mannheim, } \\
\text { Deutschland }\end{array}$ \\
\hline Transcriptor Reverse Transcriptase & Roche Diagnostics \\
\hline
\end{tabular}




\subsubsection{Bakterienstämme}

Tabelle 2.7 Verwendete Bakterienstämme

\begin{tabular}{|l|l|l|}
\hline Stamm & Genotyp & Bezugsquelle \\
\hline INV $\alpha F^{\prime}$ & $\begin{array}{l}F^{\prime} \text { endA1 recA1 hsdR17 }(r k-, m k+) \text { supE44 } \\
\text { thi-1 gyrA96 relA1 } \varphi 80 l a c Z \Delta M 15 \\
\end{array}$ & $\begin{array}{l}\text { Invitrogen GmbH, } \\
\text { (lacZYA-argF)U169 } \lambda-\end{array}$ \\
\end{tabular}

\subsubsection{Virale Ausgangsmaterialien}

Tabelle 2.8 Verwendete Ausgangs-DNA

\begin{tabular}{|c|c|}
\hline Name & Bezugsquelle \\
\hline $\begin{array}{l}\text { Humanes Adenovirus } \\
\text { C1,C2,B3,E4 } \\
\text { Zellkulturüberstände }\end{array}$ & $\begin{array}{l}\text { Freundlicherweise zur Verfügung gestellt von, } \\
\text { Prof. Dr. A. Heim, Medizinische Hochschule } \\
\text { Hannover. }\end{array}$ \\
\hline Influenza-A-Zellkulturüberstand & $\begin{array}{l}\text { Freundlicherweise zur Verfügung gestellt von, Dr. } \\
\text { M. Dilcher, Universitätsmedizin Göttingen. }\end{array}$ \\
\hline $\begin{array}{l}\text { Synthetische Influenza-B- } \\
\text { cDNS, in pCRII }{ }^{\circledR} \text {-Vektor }\end{array}$ & $\begin{array}{l}\text { Freundlicherweise zur Verfügung gestellt von, } \\
\text { PD Dr. Manfred Weidmann, Universitätsmedizin } \\
\text { Göttingen }\end{array}$ \\
\hline
\end{tabular}

\subsubsection{Plasmide}

Tabelle 2.9 Verwendete Plasmide

\begin{tabular}{|l|l|l|}
\hline Stamm & Beschreibung & Bezugsquelle \\
\hline pCRII ${ }^{\circledR}$ & 4.0kb TA-Klonierungs-Vektor & $\begin{array}{l}\text { Invitrogen GmbH, } \\
\text { Karlsruhe, Deutschland }\end{array}$ \\
\hline
\end{tabular}




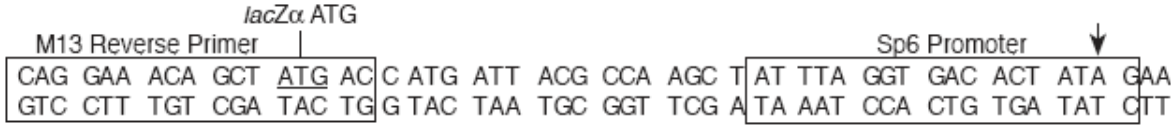

$$
\text { Nsil Hind III KpnI SacI BamHI Spe I }
$$

TAC TCA AGC TAT GCA TCA AGC TTG GTA CCG AGC TCG GAT CCA CTA GTA ACG GCC

ATG AGT TCG ATA CGT AGT TCG AAC CAT GGC TCG AGC CTA GGT GAT CAT TGC CGG

$$
\text { BstXI ECORI ECORI ECOR V }
$$
GCC AGT GTG CTG GAA TTC GGC TT PCR Product AlA GCC GAA TTC TGC AGA TAT
CGG TCA CAC GAC CTT AAG CCG AIA PCR

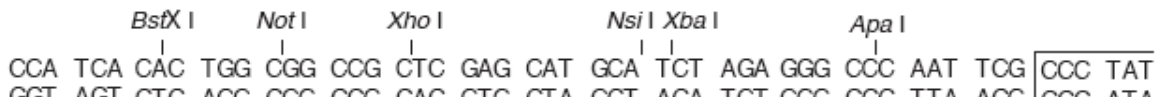
GGT AGT GTG ACC GCC GGC GAG CTC GTA CGT AGA TCT CCC GGG TTA AGC GGG ATA T7 Promoter $\quad$ M13 Forward (-20) Primer

Comments for pCR ${ }^{\circledR}$ 3971 nucleotides

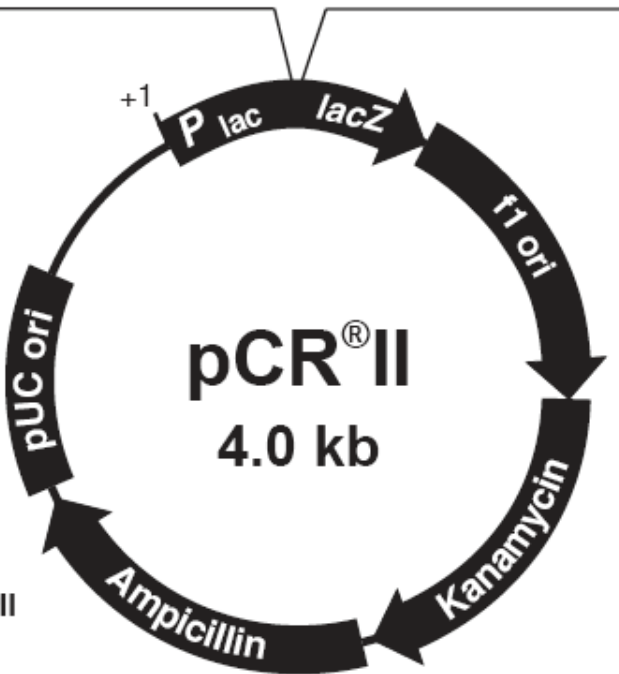

LacZ $\alpha$ gene: bases 1-587

M13 Reverse priming site: bases 205-221

Sp6 promoter: bases 239-256

T7 promoter: bases 404-423

M13 (-20) Forward priming site: bases 431-446

f1 origin: bases $588-1025$

Kanamycin resistance ORF: bases 1359-2153

Ampicillin resistance ORF: bases 2171-3031

pUC origin: bases 3176-3849

Abb. 2.1:

Schematische Darstellung des pCRII ${ }^{\circledR}$ TA-Klonierungs-Vektors und der multiplen Klonierungsstelle. Dargestellt ist die multiple Klonierungsstelle mit einem durch TAKlonierung eingefügten PCR-Produkt, verschiedene Schnittstellen für Restriktionsendonukleasen und die M13-Primerregionen. Durch die innerhalb der M13 Primer gelegenen Promotorregionen für SP6- (stromaufwärts) und T7-RNS Polymerase (stromabwärts) kann unabhängig von der Orientierung des eingefügten Fragmentes durch die Wahl der entsprechenden Polymerase die gewünschte RNS aus M13 PCR-Produkt transkribiert werden (Invitrogen 2012). 


\subsubsection{Oligonukleotide und Fluoreszenzsonden}

Tabelle 2.10 Verwendete Oligonukleotide (Hersteller: TIB-Molbiol, Berlin)

\begin{tabular}{|c|c|}
\hline Name & Sequenz 5'> 3' \\
\hline M13 For & GTAAAACGACGGCCAGT \\
\hline M13 Rev & CAGGAAACAGCTATGACC \\
\hline FluA S7for & AGATGAGTCTTCTAACCGAGGTCG \\
\hline FluA S7rev & CCTGAGTCCATGAGGGAAGAATATCAA \\
\hline InfA for(WHO) & GACCRATCCTGTCACCTCTGAC \\
\hline InfA rev(WHO) & TAGACGMTTTGTCCARAATGCCCT \\
\hline FluA UP & AACACMGATCTTGAGGCWCTCATGGAATGGC \\
\hline FluA DP & CGTCTACGCTGCAGTCCTCGCTCACTGGGCA \\
\hline FluB FP & ATACGGTGGATTAAATAAAAGC \\
\hline FluB RP & CCAGCAATAGCTCCGAAGAAA \\
\hline FluB UP & GCCTTACTACACAGGRGAACATGCAAARGC \\
\hline FluB DP & AATAGTYTTGCRGGAGGYCTATATTTGGTTCCAT \\
\hline HAdV-1C for & CATGACTTTTGAGGTGGATC \\
\hline HAdV-1C rev & CCGGCCGAGAAGGGCGTGCGCAGGTA \\
\hline HAdV-4E for & CATGAATTTCGAAGTCGA \\
\hline HAdV-4E rev & CCGGCCGAGAAGGGGGTGCGCAGGTA \\
\hline HAdV-7B for & CATGACTTTTGAGGTGGATC \\
\hline HAdV-7B rev & CCGGCCGAGAACGGTGTGCGCAGGTA \\
\hline HAdV-1C UP & GGACGAGCCCACCСTTCTTTATGTTTTGTTTGAAG \\
\hline HAdV-1C DP & CCGGCCGAGAAGGGCGTGCGCAGGTACACGGTCTC \\
\hline HAdV-4E UP & GGATGAGTCCACCСTTCTCTATGTTGTCTTCGAAG \\
\hline HAdV-4E DP & CCGGCCGAGAAGGGGGTGCGCAGGTAGACGGCCTC \\
\hline HAdV-7B UP & GGATGAGCCCACCСTGCTTTATCTTCTTTTCGAAG \\
\hline HAdV-7B DP & CCGGCCGAGAACGGTGTGCGCAGGTAGACGGCCTC \\
\hline
\end{tabular}


Tabelle 2.11 Verwendete Fluoreszenzsonden (Hersteller: TIB-Molbiol, Berlin)

\begin{tabular}{|c|c|}
\hline Name & Sequenz 5' > 3' \\
\hline InfA Probe & [FAM]CGTGCCCAGTGAGCGAGGACTGCA[BBQ] \\
\hline FluA exo Probe & $\begin{array}{l}\text { TCATGGAATGGCTAAAGACAAGACCAATCY[BHQ-dT] } \\
\text { [THF][FAM-dT] CACCTCTGACTAAGGG[3’-block] }\end{array}$ \\
\hline FluB P & [FAM]CACCCATATTGGGCAATTTCCTATGGC[BBQ] \\
\hline FluB exo Probe & $\begin{array}{l}\text { CATGCAAARGCCATAGGAAATTGCCCAA[BHQ-dT] } \\
\text { [THF][FAM-dT] GGGTGAAAACACCYTTG[3’-block] }\end{array}$ \\
\hline HAdV Probe & [FAM]CACCAGCCVCACCGCGGCG[BBQ] \\
\hline $\begin{array}{l}\text { HAdV-1C exo } \\
\text { Probe }\end{array}$ & $\begin{array}{l}\text { GAGCCCACCCTTCTTTATGTTTTGTTTGAAG[BHQ-dT] } \\
\text { [THF][FAM-dT]TTGACGTGGTCCGTGTG[3’-block] }\end{array}$ \\
\hline $\begin{array}{l}\text { HAdV-4E exo } \\
\text { Probe }\end{array}$ & $\begin{array}{l}\text { GAGTCCACCCTTCTCTATGTTGTCTTCGAAG[BHQ-dT] } \\
\text { [THF][FAM-dT]TCGACGTCGTCCGAGTG[3’-block] }\end{array}$ \\
\hline $\begin{array}{l}\text { HAdV-7B exo } \\
\text { Probe }\end{array}$ & $\begin{array}{l}\text { GAGCCCACCСTGCTTTATCTTCTTTTCGAAG[BHQ-dT] } \\
\text { [THF][FAM-dT]TCGACGTGGTCAGAGTG[3’-block] }\end{array}$ \\
\hline
\end{tabular}

\subsubsection{Computerprogramme}

Tabelle 2.12 Verwendete Computerprogramme

\begin{tabular}{|c|c|c|}
\hline Name & Hersteller & Anwendung \\
\hline EndNote ${ }^{\mathrm{TM}} \mathrm{X} 4$ & Thomson Reuters & Literaturverwaltung \\
\hline GIMP & Frei verfügbar & Bildbearbeitung \\
\hline Lasergene $^{\mathrm{TM}}$ & DNASTAR Inc & $\begin{array}{l}\text { DNA-Sequenzanalyse, Primer- } \\
\text { und Sondendesign, } \\
\text { Plasmidkonstruktion }\end{array}$ \\
\hline $\begin{array}{l}\text { Microsoft } \quad \text { Office }^{\mathrm{TM}} \\
2008\end{array}$ & Microsoft Inc. & Text- und Datenverarbeitung \\
\hline Statistica & StatSoft (Europe) GmbH & Statistische Datenanalyse \\
\hline Twista $^{\mathrm{TM}}$ Studio & TwistDx & $\begin{array}{l}\text { Aufzeichnung und Evaluation der } \\
\text { Messungen des Tube Scanners }\end{array}$ \\
\hline Visual OMPTM & DNA Software Inc. & $\begin{array}{l}\text { Sekundärstrukturberechnung, } \\
\text { Primer- und Sondendesign }\end{array}$ \\
\hline
\end{tabular}




\subsection{Methoden}

\subsubsection{Präparation viraler Nukleinsäuren}

\subsubsection{RNS/DNS-Extraktion}

Zur Extraktion viraler Nukleinsäuren aus Zellkulturüberständen wurden Reagenziensätze der Firma Qiagen verwendet. Virale DNS wurde mit dem Blood \& Cell Culture DNA Mini Kit extrahiert. Für die Extraktion viraler RNS wurde das QIAamp RNA Blood Mini Kit verwendet. Hierbei wurde nach Herstellervorgaben vorgegangen. Beide Methoden basieren auf der Bindung der Nukleinsäuren an eine Siliziummembran. Die Chromatographiesäule wurde mit ethanolhaltigem Puffer gewaschen und so von Proteinen, Kohlehydraten und Metaboliten befreit. Die Nukleinsäuren wurde abschließend mit Elutionspuffer von der Membran gelöst. Um den Erfolg der Extraktion zu beurteilen, wurde eine spektrophotometrische Messung bei 260 nm (Kapitel 2.2.2.1) durchgeführt.

\subsubsection{Reverse Transkription}

Zum Überführen viraler RNS in cDNS wurde das Transcriptor First Strand cDNA Synthesis Kit der Firma Roche ${ }^{\circledR}$ verwendet. Alle RNS-Arbeiten wurden an einer RNasefreien Sicherheitswerkbank der Schutzklasse II durchgeführt. Zunächst wurden ca. 100 ng RNS-Template mit einem spezifischen Primer (Endkonzentration $1 \mathrm{pmol} / \mu \mathrm{l}$ ) und $\mathrm{ddH}_{2} \mathrm{O}$ auf ein Volumen von $13 \mu \mathrm{l}$ aufgefüllt. Dieser Ansatz wurde, um Sekundärstrukturen aufzubrechen, 10 Minuten in einem Thermocycler auf $70^{\circ} \mathrm{C}$ erhitzt. Danach wurden Reverse Transkriptase, RNase-Inhibitor, Desoxyribonukleotide und Reaktionspuffer hinzugefügt und der Ansatz 60 min auf $60^{\circ} \mathrm{C}$ erhitzt. Danach erfolgte eine 5 minütige Inaktivierung bei $85^{\circ} \mathrm{C}$. 
Ein typischer $20 \mu \mathrm{l}$-Reaktionsansatz zur cDNS-Synthese enthielt:

\begin{tabular}{lll}
\hline Volumen & & Endkonzentration \\
\hline $\mathrm{X} \mu \mathrm{l}$ & Template-RNS (ca. $100 \mathrm{ng})$ & $\mathrm{Ca} .5 \mathrm{ng} / \mu \mathrm{l}$ \\
$\mathrm{Y} \mu \mathrm{l}$ & $\mathrm{ddH} \mathrm{H}_{2} \mathrm{O}(\mathrm{ad} 20 \mu \mathrm{l})$ & \\
$2 \mu \mathrm{l}$ & Primer $(10 \mathrm{pmol} / \mu \mathrm{l})$ & $1,0 \mathrm{pmol} / \mu \mathrm{l}$ \\
$4 \mu \mathrm{l}$ & Transkriptor $5 \mathrm{x}$ Reaktionspuffer & $1 \mathrm{x}$ \\
$0,5 \mu \mathrm{l}$ & RNase-Inhibitor $(40 \mathrm{U} / \mu \mathrm{l})$ & $1 \mathrm{U} / \mu \mathrm{l}$ \\
$2 \mu \mathrm{l}$ & $\mathrm{dNTPs}(\mathrm{je} 10 \mathrm{mM})$ & $\mathrm{je} 0,4 \mathrm{mM}$ \\
$0,5 \mu \mathrm{l}$ & Reverse Transkriptase $(20 \mathrm{U} / \mu \mathrm{l})$ & $0,5 \mathrm{U} / \mu \mathrm{l}$ \\
$\sum 20,0 \mu \mathrm{l}$ & & \\
\hline
\end{tabular}

\subsubsection{Polymerase-Kettenreaktion (PCR)}

(Mullis und Faloona 1987) (Sambrook und Russell 2001, Kapitel 8)

Um größere Mengen spezifischer DNS-Sequenzen (Template) in vitro exponentiell zu amplifizieren, wurde die Polymerase-Kettenreaktion (englisch: Polymerase Chain Reaction, PCR) verwendet. Dieses Verfahren benötigt eine geringe Menge einer DNSZielsequenz, zwei spezifische Oligonukleotidprimer, eine thermostabile DNS-Polymerase (in der Regel aus dem Bakterium Thermus aquaticus) und die vier verschiedenen Desoxyribonukleotide als Bausteine der DNS. Es basiert auf der zyklischen Denaturierung von DNS-Doppelsträngen durch Erhitzen und der semikonservativen Replikation des Templates durch DNS-Polymerase. Dies erfolgte in einem programmierbaren Thermocycler mit beheiztem Deckel in dünnwandigen $0,5 \mathrm{ml}$ Reaktionsgefäßen folgendermaßen:

\section{Denaturierung}

Die Probe wurde zur thermischen Denaturierung eine Minute auf $95^{\circ} \mathrm{C}$ erhitzt.

\section{Renaturierung (Annealing)}

Die Probe wurde für eine Minute auf eine Temperatur ca. $5^{\circ} \mathrm{C}$ unterhalb der berechneten Schmelztemperatur ( $\left.\mathrm{T}_{\mathrm{m}}\right)$ der Primer (Firma TIB-Molbiol, Berlin) abgekühlt. In dieser Phase lagern sich die Oligonukleotide an komplementäre DNS-Abschnitte an. 


\section{Synthese (Elongation)}

Die Probe wurde für eine Minute auf $68{ }^{\circ} \mathrm{C}$ erhitzt. Dies ist das Temperaturoptimum der verwendeten DNS-Polymerase. Diese ergänzt, ausgehend vom 3'-Ende der hybridisierten Oligonukleotide, den komplementären Gegenstrang der Ziel-DNS. Die Dauer dieses Schrittes richtet sich nach der Prozessivität der verwendeten DNS-Polymerase und der Größe des Amplikons. Durch 30malige Wiederholung dieses Ablaufes kommt es zu einer exponentiellen Amplifikation der durch die Primer begrenzten Zielsequenz.

Ein typischer $50 \mu \mathrm{l}$ PCR-Ansatz enthielt:

\begin{tabular}{lll}
\hline Volumen & & Endkonzentration \\
\hline $\mathrm{X} \mu \mathrm{l}$ & Template-DNS (ca. 5-30 ng) & $0,1-0,6 \mathrm{ng} / \mu \mathrm{l}$ \\
$\mathrm{Y} \mu \mathrm{l}$ & $\mathrm{ddH}_{2} \mathrm{O}(\mathrm{ad} 50 \mu \mathrm{l})$ & \\
$1 \mu \mathrm{l}$ & Primer A $(10 \mathrm{pmol} / \mu \mathrm{l})$ & $0,2 \mathrm{pmol} / \mu \mathrm{l}$ \\
$1 \mu \mathrm{l}$ & Primer B $(10 \mathrm{pmol} / \mu \mathrm{l})$ & $0,2 \mathrm{pmol} / \mu \mathrm{l}$ \\
$1 \mu \mathrm{l}$ & $\mathrm{dNTPs}(\mathrm{je} 10 \mathrm{mM})$ & je $0,2 \mathrm{mM}$ \\
$1 \mu \mathrm{l}$ & Taq DNS-Polymerase $(5 \mathrm{U} / \mu \mathrm{l})$ & $0,1 \mathrm{U} / \mu \mathrm{l}$ \\
$\sum 50,0 \mu \mathrm{l}$ & & \\
\hline
\end{tabular}

Das Amplifikationsprodukt wurde durch Agarose-Gelelektrophorese analysiert (Vergl. Kapitel 2.2.1.4).

\subsubsection{Agarosegelelektophorese}

Zur Beurteilung des Erfolges der TA-Klonierungen und zum Aufreinigen von DNSProben wurden analytische und präparative Agarosegelelektrophoresen durchgeführt. Dabei wurde der Sachverhalt ausgenutzt, dass aufgrund der negativen Ladung ihrer Phosphatgruppen DNS im elektrischen Feld zur Anode wandert. Bei geringen Spannungen ist die Geschwindigkeit der DNS-Fragmente im Agarosegel umgekehrt proportional zum Logarithmus ihres Molekulargewichtes (Helling et al. 1974). Das 
bedeutet kleine Fragmente wandern schneller zur Anode als große und ermöglichen so eine räumliche Auftrennung der DNS-Fragmente nach ihrer Länge.

Die Gelelektrophoresen wurden in Agarose-Flachbettgelen mit einer Agarosekonzentration von 1-2 \% (w/v) durchgeführt. Dazu wurde die Agarose zunächst in TAE-Puffer aufgekocht, bis sie vollständig gelöst war. Nach dem Abkühlen auf ca. $60^{\circ} \mathrm{C}$ wurde der interkalierende Farbstoff Ethidiumbromid in einer Endkonzentration von 0,5 $\mu \mathrm{g} / \mathrm{ml}$ zugegeben. Sämtliche Arbeitsschritte mit dem kanzerogenen Ethidiumbromid erfordern spezielle chemikaliendichte Handschuhe. Das Gel wurde in eine Gelkammer gegossen, wobei Taschen zur späteren Probenauftragung durch einen Kamm freigehalten wurden. Nach dem Polymerisieren des Gels wurde es in eine Gelelektrophoresekammer überführt und die Taschen mit TAE-Puffer bedeckt. Die Proben wurden mit 1/6 Volumen 6x Orange Loading Dye (Fermentas) versetzt und mit einer Pipette in die Geltaschen gegeben. Zum Vergleich wurden zusätzlich DNS-Längenstandards (GenRuler ${ }^{\mathrm{TM}}$ DNA Ladder, Fermentas) aufgetragen. Präparative Gele wurden bei 60V, analytische Gele bei 120V so lange dem elektrischen Feld ausgesetzt, bis der im Ladepuffer enthaltene Farbmarker etwa bis zur Mitte des Gels gelaufen war. Zur Darstellung der DNS wurde das Gel in einer Chemidoc-XRS-Geldokumentationskammer mit UV-Licht bestrahlt. Die Ergebnisse wurden fotografisch dokumentiert. Dabei ist von einer Nachweisgrenze von ca. 10 ng DNS auszugehen. Bei präparativen Gelen wurden die entsprechenden Banden mit einem Messer ausgeschnitten und in ein Eppendorfgefäß überführt. Die DNSExtraktion erfolgte mit dem Zymoclean ${ }^{\mathrm{TM}}$ Gel Recovery Kit (Vergleiche Kapitel 2.2.1.5).

\subsubsection{DNS-Extraktion aus präparativen Agarosegelen}

Die DNS-Extraktion aus Agarosegelen wurde mit dem Zymoclean ${ }^{\mathrm{TM}}$ Gel Recovery Kit der Firma Zymo Research entsprechend den Herstellerangaben durchgeführt. Das zu extrahierende Gelfragment wurde unter UV-Licht (Wellenlänge 302nm) ausgeschnitten und in ein $2 \mathrm{ml}$ Eppendorfgefäß überführt. Das Volumen des Fragmentes wurde durch Wiegen abgeschätzt. Pro 100 mg Gel wurden $300 \mu \mathrm{l}$ ABD Buffer ${ }^{\mathrm{TM}}$ hinzugefügt. Danach wurde die Probe so lange bei $55^{\circ} \mathrm{C}$ inkubiert, bis das Gelfragment vollständig gelöst war. Nach dem Auftragen auf das im Reagenziensatz enthaltene Säulensystem wurde die Probe 1 Minute bei 10000 UpM zentrifugiert. Der Durchfluss wurde verworfen. Die an 
die Siliziummembran der Säule gebundene DNS wurde 2 Mal bei 10000UpM mit 200 $\mu$ l ethanolhaltigem Waschpuffer 30 sec. gewaschen. Der Durchfluss wurde verworfen. Die Säule wurde durch einminütige Leerzentrifugation getrocknet. Die DNS wurde mit $10 \mu \mathrm{l}$ $\mathrm{ddH}_{2} \mathrm{O}$ in ein Eppendorfgefäß eluiert. Um den Erfolg der Extraktion zu beurteilen, wurde eine spektrophotometrische Messung der im Eluat enthaltenen DNS-Konzentration durchgeführt (Kapitel 2.2.2.1).

\subsubsection{Ligation von dsDNS-Fragmenten}

Zum Einfügen von viralen Nukleinsäuresequenzen in pCRII ${ }^{\circledR}-$ Vector wurde das Verfahren des sogenannten TA-Klonierens gewählt. Die Adenosin-Überhänge, welche Taq-Polymerase an die 3'-Enden eines Amplicons anfügt, wurden dabei genutzt, um dieses mit den T-Überhängen des Vektors mit Hilfe von T4-DNS-Ligase zu verbinden (vergl. Abb. 2.1). Dazu wurde das TA-Cloning Kit Dual Promotor (pCRII®) der Firma Invitrogen verwendet. Die Reaktion wurde bei $14^{\circ} \mathrm{C}$ über Nacht durchgeführt.

Ein typischer $10 \mu \mathrm{l}-$ Reaktionsansatz enthielt:

\begin{tabular}{lll}
\hline Volumen & & Endkonzentration \\
\hline $\mathrm{X} \mu \mathrm{l}$ & $\begin{array}{l}\text { Template-DNS (PCR-Produkt) } \\
(\text { ca. } 50 \mathrm{ng})\end{array}$ & $5 \mathrm{ng} / \mu \mathrm{l}$ \\
$\mathrm{Y} \mu \mathrm{l}$ & $\mathrm{ddH}_{2} \mathrm{O}(\mathrm{ad} 10 \mu \mathrm{l})$ & \\
$2 \mu \mathrm{l}$ & pCRII ${ }^{\circledR}$ Vector $(25 \mathrm{ng} / \mu \mathrm{l})$ & $5 \mathrm{ng} / \mu \mathrm{l}$ \\
$1 \mu \mathrm{l}$ & $10 \mathrm{x}$ Puffer & $1 \mathrm{x}$ \\
$1 \mu \mathrm{l}$ & T4 DNA Ligase $(4 \mathrm{U} / \mu \mathrm{l})$ & $0,4 \mathrm{U} / \mu \mathrm{l}$ \\
$\sum 10,0 \mu \mathrm{l}$ & & \\
\hline
\end{tabular}

Dabei können sowohl Vektor mit Insert in Positiv- oder Negativstrangorientierung als auch relegierter Vektor ohne Insert entstehen. Vektoren ohne Insert weisen eine intakte Laktaseaktivität auf, durch das Einfügen des Inserts in die multiple Klonierungsstelle geht diese verloren. Das in dieser Reaktion entstandene Ligationsprodukt wurde verwendet, um chemisch Kompetente E. coli-Bakterien zu transformieren (Kapitel 2.2.1.8). Durch 
Zugabe von Ampicillin wurden Klone selektiert, die das Plasmid aufgenommen hatten, da dieses ein Resistenzgen beinhaltet. Durch Verwendung eines Farbindikators wurden Klone gewählt, die keine Laktaseaktivität aufwiesen. Es wurden 8 Klone in Flüssigmedium überführt.

\subsubsection{Nährmedien für $E$. coli}

(Bertani 1951)

Für die Anzucht der chemisch kompetenten E. coli-Bakterien wurde mit Antibiotikum versetztes LB-Luria-Medium (0,5 g/l $\mathrm{NaCl})$ und LB-Luria-Agar verwendet. In diesen Medien wachsen nur Bakterien, die ein im pCRII®-Plasmid enthaltenes Resistenzgen tragen. Alle Medien wurden 20 Minuten bei $120^{\circ} \mathrm{C}$ autoklaviert. Für die Herstellung von Agarplatten wurde dem Medium Bacto-Agar in einer Endkonzentration von 1,5\% (w/v) zugesetzt. Nach Abkühlen auf ca. $50^{\circ} \mathrm{C}$ wurde Ampicillin (Endkonzentration 50 mg/ml) bzw. Kanamycin (Endkonzentration 100 mg/ml) zugefügt. Die gegossenen Agarplatten wurden bei $4^{\circ} \mathrm{C}$ gelagert.

\subsubsection{Tansformation von chemisch kompetenten $E$. coli-INV $\alpha F^{\prime}$-Bakterien}

Zur Transformation der chemisch kompetenten E. coli-INV $\alpha$ F'-Bakterien wurden $2 \mu \mathrm{l}$ Ligationsansatz (Vergl Kapitel 2.2.1.6) mit $50 \mu \mathrm{l}$ INV $\alpha F^{\prime}$ kompetenten Zellen gemischt. Die Probe wurde 30 min auf Eis gestellt und danach 30 sec auf $42{ }^{\circ} \mathrm{C}$ erhitzt. Danach wurde die Probe wieder auf Eis gestellt und $250 \mu$ l SOC-Medium hinzugegeben. Dieser Ansatz wurde $1 \mathrm{~h}$ bei $37^{\circ} \mathrm{C} 300 \mathrm{rpm}$ inkubiert. Je $100 \mu \mathrm{l}$ wurden auf zuvor mit $80 \mu \mathrm{l} \mathrm{X-Gal}$ (20mg/ml) behandelten LB-Amp-Agarplatten ausgestrichen. Die Platten wurden bei $37^{\circ} \mathrm{C}$ über Nacht inkubiert. Mehrere weiße Klone wurden in monoklonale Flüssigkulturen überführt. Der Erfolg der Transformation wurde mittels DNS-Minipräparation (Kapitel 2.2.1.11) überprüft.

\subsubsection{Anzucht von $E$. coli-Flüssigkulturen}

Zur Anlage einer Flüssigkultur wurde eine monoklonale Bakterienkolonie mit Hilfe einer sterilen Pipettenspitze in Flüssigmedium überführt. Die Flüssigkulturen wurden in $15 \mathrm{ml}$ Falkonröhrchen mit 5 ml LB amp-Medium mit $120 \mathrm{UpM}$ ü.N. bei $37^{\circ} \mathrm{C}$ geschüttelt. 


\subsubsection{Anlage von Bakteriendauerkulturen}

Zum Konservieren von monoklonalen bakteriellen Flüssigkulturen wurden $850 \mu \mathrm{l}$ Flüssigkultur mit $150 \mu$ l Glycerin (87\%) gemischt und in einem Mikroschaubgefäß bei $80{ }^{\circ} \mathrm{C}$ eingefroren.

\subsubsection{DNS-Minipräparation}

Zur Gewinnung kleinerer Mengen von bis zu 25 $\mu$ g Plasmid-DNS aus Bakterienkulturen wurde eine DNS-Minipräparation mit dem peqGOLD Miniprep Kit I durchgeführt. Dies diente in Kombination mit einem anschließenden Restriktionsverdau und einer analytischen Gelelektrophorese der Beurteilung des Erfolges einer TA-Klonierung. Dieses Verfahren stellt eine Kombination der alkalischen Lyse mit der säulenchromatographischen Aufeinigung der DNS an einer Siliziummembran dar (Sambrook und Russell 2001). Die Bakterien wurden lysiert und die DNS durch Alkalibehandlung denaturiert und ausgefällt. Die Plasmid-DNS fällt dabei zunächst zusammen mit der genomischen DNS und anderen Bestandteilen aus, sie wird jedoch durch eine Erhöhung der Salzkonzentration wieder in Lösung gebracht. Durch Abzentrifugieren der ungelösten Bestandteile und Aufreinigung der DNS mithilfe einer Chromatographiesäule wurde die Plasmid-DNS von den Restbestandteilen getrennt. RNSReste wurden durch RNase-Behandlung entfernt.

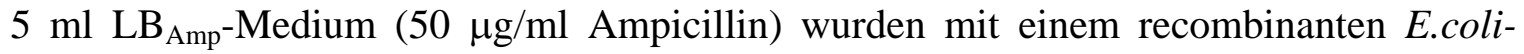
Bakterienklon angeimpft und bei $37^{\circ} \mathrm{C}$ in einem Schüttelinkubator über Nacht inkubiert. $850 \mu \mathrm{l}$ der Bakteriensuspension wurden als Glycerindauerkultur gesichert (Kapitel 2.2.1.10). $2 \mathrm{ml}$ der Bakteriensuspension wurden in ein Eppendorfgefäß überführt und durch einminütiges Zentrifugieren bei Raumtemperatur mit 10000 x g pelletiert. Der Überstand wurde verworfen. Das Pellet wurde durch vortexen in $250 \mu \mathrm{l}$ Lösung I/RNase A resuspendiert. $250 \mu \mathrm{l}$ Lösung II wurden hinzugegeben und die Probe durch sechs- bis zehnmaliges Invertieren gemischt. Das aufgeklarte Lysat wurde mit $350 \mu$ l Lösung III neutralisiert und erneut sechs- bis zehn Mal invertiert. Danach wurde die Probe 5 min bei 10000 x g zentrifugiert. Der klare Überstand wurde ohne Pellet auf die mitgelieferte Säule durch einminütiges Zentrifugieren bei 10000 x g übertragen. Der Durchfluss wurde verworfen. Die an die Säule gebundene DNS wurde zunächst mit $500 \mu$ l Plasmid Buffer für eine Minute bei 10000 x g gewaschen. Der Waschschritt wurde mit $750 \mu \mathrm{l}$ DNA Wash 
Buffer wiederholt. Die Säule wurde durch zweiminütiges Leerzentrifugieren getrocknet.

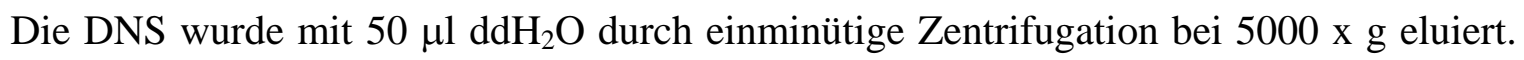
Zur Kontrolle der Reinheit und Konzentration der gewonnenen DNS wurde eine spektrophotometrische Messung durchgeführt (Kapitel 2.2.2.1).

\subsubsection{DNS-Midipräparation}

Zur Gewinnung größerer Mengen Plasmid-DNS (100-300 $\mu \mathrm{g}$ ) aus Bakterienkulturen wurde eine DNS-Midipräparation mit dem Quantum Prep ${ }^{\mathrm{TM}}$ Plasmid Midiprep Kit durchgeführt. Dieses Verfahren basiert auf der Bindung der Plasmid-DNS an eine Siliciumdioxyd Matrix. Für die Präparation wurden $40 \mathrm{ml}$ Bakterienflüssigkultur verwendet. Der Ablauf der Präparation entsprach den Herstellervorgaben. Die Plasmid-

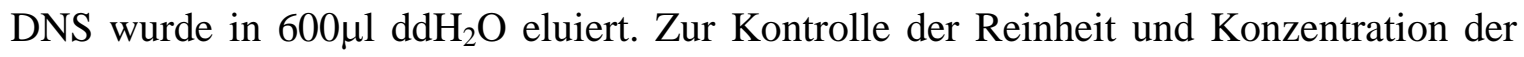
gewonnenen DNS wurde eine spektrophotometrische Messung durchgeführt (Kapitel 2.2.2.1).

\subsubsection{Restriktionsverdau}

(Sambrook und Russell 2001, S. A4.1f)

Zum Linearisieren von Plasmid-DNS und zur Analyse des Erfolges von TAKlonierungen wurde die DNS mit Restriktionsendonucleasen verdaut. Diese katalysieren die hydrolytische Spaltung der Phosphodiesterbindung der DNS innerhalb spezifischer Zielsequenzen. Dafür wurden FastDigest ${ }^{\circledR}$ Enzyme der Firma Fermentas mit dem mitgelieferten Reaktionspuffer verwendet. Dabei wurden die Reaktionsbedingungen den Herstellervorgaben entsprechend gewählt. Der Ansatz wurde in ein EppendorfReaktionsgefäß gegeben, gemischt und für 20 min bei $37^{\circ} \mathrm{C}$ auf einem Thermoblock inkubiert. $10 \mu \mathrm{l}$ Restriktionsansatz wurden mit $2 \mu \mathrm{l}$ 6x Orange Loading Dye gemischt und je $10 \mu \mathrm{l}$ in einem analytischen Agarosegel elektrophoretisch aufgetrennt. 
Beispiel: Analytischer Doppelverdau von Plasmid-DNS

\begin{tabular}{lll}
\hline Volumen & & Endkonzentration \\
\hline $\mathrm{X} \mu \mathrm{l}$ & $\begin{array}{l}\text { Plasmid-Minipräperations-DNS } \\
(\text { ca. } 300 \mathrm{ng})\end{array}$ & Ca. $30 \mathrm{ng} / \mu \mathrm{l}$ \\
$\mathrm{Y} \mu \mathrm{l}$ & $\mathrm{ddH}_{2} \mathrm{O}(\mathrm{ad} 10 \mu \mathrm{l})$ & \\
$0,5 \mu \mathrm{l}$ & FastDiges ${ }^{\circledR}$ Enzym A & \\
$0,5 \mu \mathrm{l}$ & FastDiges ${ }^{\circledR}$ Enzym B & $1 \mathrm{X}$ \\
$1,0 \mu \mathrm{l}$ & 10x FastDigest ${ }^{\circledR}$ Buffer & \\
$\sum 10,0 \mu \mathrm{l}$ & & \\
\hline
\end{tabular}

\subsubsection{Sequenzierung der Inserts}

Die Sequenzierung von DNS-Fragmenten erfolgte durch die Firma SeqLab nach der Kettenabbruchmethode nach Sanger (Sanger et al. 1977) mit fluoreszenzmarkierten Didesoxynukleotiden. Dazu wurden ca. 600 ng aufgereinigter Plasmid-DNS mit Primer in einer Endkonzentration von 2,5 pmol/ $\mu \mathrm{l}$ und $\mathrm{ddH}_{2} \mathrm{O}$ auf ein Gesamtvolumen von $8 \mu \mathrm{l}$ aufgefüllt und an SeqLab übergeben. Als Primer diente ein Abschnitt des verwendeten Vectors in Nähe der multiplen Klonierungsstelle.

\subsubsection{Transkription}

Zur in Vitro Transkription von DNS, die der Herstellung von RNS-Standards diente, wurde der SP6/T7 Transcripton Reagenziensatz der Firma Roche verwendet. Als DNSVorlage diente ein aus dem jeweiligen Standardplasmid erzeugtes M13 PCR-Produkt (M13 FP, M13 RP). Dieses PCR-Produkt beinhaltet am 5'-Ende des Positivstranges den SP6-Promotor und am 3'-Ende den T7-Promotor. Diese Promotoren rahmen die multiple Klonierungsstelle des Vektors derart ein, dass je nach Orientierung des Inserts durch Wahl der korrespondierenden RNS-Polymerase ein der viralen RNS entsprechendes RNS-Fragment transkribiert werden kann (vergl. Abb. 2.1). Im Falle des negativ orientierten Inserts des Influenza-A-Plasmids wurde SP6-RNS-Polymerase verwendet. Für das im Vektor positiv orientierte Influenza-B-Insert wurde T7-RNS-Polymerase 
verwendet. Die Transkription wurde den Herstellervorgaben entsprechend durchgeführt. Nach abgeschlossener Transkription wurde die DNS durch DNase-Behandlung entfernt (Kapitel 2.2.1.16).

\subsubsection{DNase-Behandlung}

Zum Entfernen unerwünschter DNS aus RNS-Standardlösungen wurde der Ambion ${ }^{\circledR}$ DNA-free ${ }^{\mathrm{TM}}$ DNase Treatment \& Removal Reagenziensatz verwendet. Es wurden zunächst $89 \mu \mathrm{l}$ Transkriptionsprodukt mit $10 \mu \mathrm{l}$ Puffer (10x) und $1 \mu$ l Turbo DNase vermischt und $30 \mathrm{~min}$ bei $37^{\circ} \mathrm{C}$ inkubiert. Danach wurden $10 \mu \mathrm{l}$ Inaktivationsreagenz hinzugefügt und der Ansatz 5 min bei Raumtemperatur unter gelegentlichem Vortexen inkubiert. Nach 1,5 minütiger Zentrifugation bei 10000 x g wurde der Überstand in ein neues Eppendorfgefäß überführt.

\subsubsection{Herstellug quantitativer molekularer Standards}

\subsubsection{Spektrophotometrische Konzentrationsbestimmung}

Zur Bestimmung der Konzentration und Reinheit von DNS- und RNS-Proben wurden spektrophotometrische Messungen mit einem NanoDrop ND-1000 Photometer durchgeführt. Die Messung bei 260 nm Wellenlänge erlaubt die Berechnung der Nukleinsäurekonzentration der Probe. Eine OD von 1 entspricht ca. $50 \mu \mathrm{g} / \mathrm{ml}$ dsDNS, ca. $40 \mu \mathrm{g} / \mathrm{ml}$ ssDNS oder RNS sowie ca. $33 \mu \mathrm{g} / \mathrm{ml}$ Oligonucleotiden. (Sambrook und Russell 2001, Appendix 8). Verunreinigungen durch aromatische Aminosäure und Phenol können durch Messung bei $280 \mathrm{~nm}$ Wellenlänge abgeschätzt werden. Der Quotient $\mathrm{OD}_{260} / \mathrm{OD}_{280}$ sollte bei einer relativ reinen Nukleinsäureprobe zwischen 1,8 und 2 liegen. Das Gerät wurde auf den entsprechenden Probenpuffer bzw. $\mathrm{ddH}_{2} \mathrm{O}$ geeicht. Zur Messung wurden 1,5 $\mu$ l Probenvolumen eingesetzt.

\subsubsection{PicoGreen ${ }^{\circledR}$-DNS-Konzentrationsbestimmung}

Zur genauen Bestimmung der DNS-Konzentration und entsprechenden Verdünnung der quantitativen molekularen DNS-Standards wurde der Quant-iT ${ }^{\mathrm{TM}}$ PicoGreen ${ }^{\circledR}$ dsDNA Assay Reagenziensatz der Firma Invitrogen ${ }^{\mathrm{TM}}$ nach Herstellerangaben verwendet. Dieses Verfahren nutzt einen DNS-spezifischen Fluoreszenzfarbstoff und bestimmt die Konzentration photometrisch anhand einer mitgelieferten Standardreihe. Gegenüber der 
spektrophotometrischen Messung bei $260 \mathrm{~nm}$ hat dieses Verfahren den Vorteil einer geringeren Anfälligkeit gegenüber Verunreinigungen durch Proteine oder freier Nukleotide. Die photometrischen Messungen wurden mit einer Exzitation von $500 \mathrm{~nm}$ in einem FLUOstar Optima Microplate Fluorometer durchgeführt. Die Emission wurde bei 525 nm gemessen.

\subsubsection{RiboGreen ${ }^{\circledR}-$ RNS-Konzentrationsbestimmung}

Die genaue RNS-Konzentration quantitativer molekularer Standards wurde, analog zur PicoGreen ${ }^{\circledR}$-Messung (Kapitel 2.2.2.2), mit einem Quant-iT ${ }^{\mathrm{TM}}$ RiboGreen ${ }^{\circledR}$ RNA Assay Reagenziensatz der Firma Invitrogen ${ }^{\mathrm{TM}}$ nach Herstellerangaben gemessen. Die photometrischen Messungen wurden mit einer Exzitation von $500 \mathrm{~nm}$ in einem FLUOstar Optima Microplate Fluorometer durchgeführt. Die Emission wurde bei 525 nm gemessen.

\subsubsection{Molekülzahl-Berechnung}

Nach der Konzentrationsbestimmung der Nukleinsäurelösungen für die Herstellung der quantitativen Standards wurde die Anzahl der enthaltenen Moleküle berechnet. Dazu wurde zunächst die molare Masse der jeweiligen Standardsequenz anhand ihrer Länge berechnet. Bei einzelsträngiger RNS wurde von einer molaren Masse von 330 g/mol pro Nukleotid und bei doppelsträngiger DNS von 660 g/mol pro Basenpaar ausgegangen. Die genaue Molekühlzahl wurde anhand der Avogadro-Konstante: $\mathrm{N}_{\mathrm{A}}=6,02214129 \times 10^{23}$ $\mathrm{mol}^{-1}$ und der molaren Masse nach folgender Formel berechnet:

Moleküle pro $\mu \mathrm{l}\left[\mu \mathrm{l}^{-1}\right]=$

(Nukleinsäurekonzentration [g/ $\mu \mathrm{l}] /$ molare Masse $[\mathrm{g} / \mathrm{mol}]$ ) x 6,02214 x $10^{23}\left[\mathrm{~mol}^{-1}\right]$

Entsprechend der berechneten Molekülzahl wurden Verdünnungsreihen angelegt, um quantitativ definierte Standardlösungen mit 10 bis $10^{7}$ Molekülen / $\mu \mathrm{l}$ zu erhalten. DNSStandards wurden in TE-Puffer, RNS-Standards in $100 \mathrm{ng} / \mu \mathrm{l}$ tRNS Lösung verdünnt.

\subsubsection{Echtzeit-PCR}

Analog zur Amplifikation von DNS mittels klassischer Polymerase-Kettenreaktion wurden zur Qualitätskontrolle der quantitativen DNS-Standards Echtzeit-PCRReaktionen durchgeführt. Dafür wurde der Light Cycler ${ }^{\circledR}$ Fast start DNA Master 
HybProbe-Reagenziensatz der Firma Roche verwendet. $\mathrm{Zu}$ den enthaltenen Reagenzien wurden lediglich zwei spezifische Primer und eine Fluoreszenzsonde hinzugefügt. Dabei macht sich die Echtzeit-PCR den Fluoreszenz-Energietransfer nach Förster (Förster 1948) sowie die 5'->3'-Exonukleaseaktivität der verwendeten Polymerase zunutze. In einer spezifisch bindenden Fluoreszenzsonde liegen ein Fluoreszenzfarbstoff und ein Quencher, der die Fluoreszenzenergie aufnehmen kann, in direkter Nachbarschaft. Nur wenn diese Sonde spezifisch an das Zielmolekül gebunden ist, werden Flurophor und Quencher durch die Exonukleaseaktivität der Polymerase während der Replikation separiert. Fluoreszenzfarbstoff und Quencher werden getrennt und der Amplifikationsprozess kann fluoreszenzphotometrisch in Echtzeit gemessen werden. Die Messung wurde in einem Roche LightCycler® 2.0 durchgeführt.

Ein typischer $20 \mu \mathrm{l}$-Reaktionsansatz enthielt:

\begin{tabular}{|c|c|c|}
\hline Volumen & & Endkonzentration \\
\hline $\mathrm{X} \mu \mathrm{l}$ & $\mathrm{ddH}_{2} \mathrm{O}$ ad $20 \mu \mathrm{l}$ & \\
\hline $1,0 \mu \mathrm{l}$ & Primer A $(10 \mu \mathrm{M})$ & $500 \mathrm{nM}$ \\
\hline $1,0 \mu \mathrm{l}$ & Primer B $(10 \mu \mathrm{M})$ & $500 \mathrm{nM}$ \\
\hline $0,4 \mu \mathrm{l}$ & Fluoreszenzsonde $(10 \mu \mathrm{M})$ & $200 \mathrm{nM}$ \\
\hline $4,0 \mu \mathrm{l}$ & $\mathrm{MgCl}_{2}(25 \mathrm{mM})$ & $5 \mathrm{mM}$ \\
\hline \multirow[t]{3}{*}{$2,0 \mu \mathrm{l}$} & 10x Reaktionslösung: Light & $1 \mathrm{X}$ \\
\hline & Cycler ${ }^{\circledR}$ Fast start DNA Master & \\
\hline & HybProbe & \\
\hline $1,0 \mu \mathrm{l}$ & Probe & \\
\hline$\sum 20,0 \mu 1$ & & \\
\hline
\end{tabular}

Die Stammlösung für die Reaktion wurde dabei räumlich getrennt von der zu untersuchenden Probe zusammengestellt, um Kontaminationen zu vermeiden. 
Es wurden 45 Thermozyklen nach folgendem Schema durchlaufen:

\begin{tabular}{llll}
\hline & Temperatur & Zeit & Wiederholungen \\
\hline Aktivierung & $95^{\circ} \mathrm{C}$ & 30 sec. & $1 \mathrm{X}$ \\
PCR & & & \\
Denaturierung & $95^{\circ} \mathrm{C}$ & 15 sec. & $45 \mathrm{X}$ \\
Annealing & $60^{\circ} \mathrm{C}$ & 30 sec. \\
Elongation & $60^{\circ} \mathrm{C}$ & 30 sec. \\
Kühlung & $40^{\circ} \mathrm{C}$ & 30 sec. & $1 \mathrm{X}$ \\
\hline
\end{tabular}

Die Annealingtemperatur wurde ca. $5^{\circ} \mathrm{C}$ unterhalb der berechneten Schmelztemperatur $\left(\mathrm{T}_{\mathrm{m}}\right)$ der Primer gewählt. Am Ende jeder Elongationsphase wurde die Fluoreszenzintensität bei einer Emissionswellenlänge von 530 nm gemessen.

\subsubsection{Echtzeit-RT-PCR}

Zur Qualitätskontrolle der quantitativen RNS-Standards wurden Echtzeit-ReverseTranskriptase-PCR-Reaktionen durchgeführt. Es wurde der Light Cycler® 480 RNA Master Hydrolysis Probe-Reagenziensatz der Firma Roche nach Herstellervorgaben verwendet. Diese Reaktion basiert auf der in Kapitel 2.2.2.5 beschriebenen Echtzeit-PCR Technik. Der Reaktion wird jedoch ein reverser Transkriptionsschritt vorangestellt, um aus RNS cDNS zu erzeugen, die dann als Vorlage für die darauffolgende PCR diente. Die Stammlösung für die Reaktion wurde räumlich getrennt von der zu untersuchenden Probe zusammengestellt, um Kontaminationen zu vermeiden. 
Ein typischer $20 \mu$ l Echtzeit-RT-PCR-Reaktionsansatz enthielt:

\begin{tabular}{|c|c|c|}
\hline Volumen & & Endkonzentration \\
\hline $\mathrm{X} \mu \mathrm{l}$ & $\mathrm{ddH}_{2} \mathrm{O}$ ad $20 \mu \mathrm{l}$ & \\
\hline $1,0 \mu \mathrm{l}$ & Primer A $(10 \mu \mathrm{M})$ & $500 \mathrm{nM}$ \\
\hline $1,0 \mu \mathrm{l}$ & Primer B $(10 \mu \mathrm{M})$ & $500 \mathrm{nM}$ \\
\hline $0,4 \mu \mathrm{l}$ & Fluoreszenzsonde $(10 \mu \mathrm{M})$ & $200 \mathrm{nM}$ \\
\hline $1,3 \mu \mathrm{l}$ & Aktivator & \\
\hline $7,5 \mu \mathrm{l}$ & $\begin{array}{l}\text { Light Cycler }{ }^{\circledR} 480 \text { RNA Master } \\
\text { Hydrolysis Probe }(2,7 \text { X) }\end{array}$ & $1 \mathrm{X}$ \\
\hline $1,0 \mu \mathrm{l}$ & Probe & \\
\hline$\sum 20,0 \mu 1$ & & \\
\hline
\end{tabular}

Es wurden 45 Thermozyklen nach folgendem Schema durchlaufen:

\begin{tabular}{llll}
\hline & Temperatur & Zeit & Wiederholungen \\
\hline Reverse Transkription & $63^{\circ} \mathrm{C}$ & $3 \mathrm{~min}$. & $1 \mathrm{X}$ \\
Aktivierung & $95^{\circ} \mathrm{C}$ & $30 \mathrm{sec}$. & $1 \mathrm{X}$ \\
PCR & & & \\
Denaturierung & $95^{\circ} \mathrm{C}$ & $15 \mathrm{sec}$. & $45 \mathrm{X}$ \\
Annealing & $60^{\circ} \mathrm{C}$ & $30 \mathrm{sec}$. & \\
Elongation & $60^{\circ} \mathrm{C}$ & $30 \mathrm{sec}$. & \\
Kühlung & $40^{\circ} \mathrm{C}$ & $30 \mathrm{sec}$. & $1 \mathrm{X}$ \\
\hline
\end{tabular}

Die Annealingtemperatur wurde ca. $5^{\circ} \mathrm{C}$ unterhalb der berechneten Schmelztemperatur $\left(\mathrm{T}_{\mathrm{m}}\right)$ der Primer gewählt. Am Ende jeder Elongationsphase wurde die Fluoreszenzintensität bei einer Emissionswellenlänge von 530 nm gemessen. 


\subsubsection{Rekombinase-Polymerase-Amplifikation}

\subsubsection{RPA (DNS)}

Die Rekombinase-Polymerase-Amplifikation viraler DNS wurde mit dem TwistAmp ${ }^{\mathrm{TM}}$ exo Kit durchgeführt. $\mathrm{Zu}$ den bereits enthaltenen Reagenzien wurden lediglich spezifische Primer und eine Fluoreszenzsonde hinzugefügt.

Ein typischer $50 \mu \mathrm{l}$-Reaktionsansatz enthielt:

\begin{tabular}{lll}
\hline Volumen & & Endkonzentration \\
\hline $2,1 \mu \mathrm{l}$ & Primer A $(10 \mu \mathrm{M})$ & $420 \mathrm{nM}$ \\
$2,1 \mu \mathrm{l}$ & Primer B $(10 \mu \mathrm{M})$ & $420 \mathrm{nM}$ \\
$0,6 \mu \mathrm{l}$ & exoProbe A $(10 \mu \mathrm{M})$ & $120 \mathrm{nM}$ \\
$29,5 \mu \mathrm{l}$ & Rehydratationspuffer $(1,7 \mathrm{X})$ & $1 \mathrm{X}$ \\
$12,2 \mu \mathrm{l}$ & dd ${ }_{2} \mathrm{O}$ & \\
$2,5 \mu \mathrm{l}$ & Mg-Acetat $(280 \mathrm{mM})$ & $14 \mathrm{mM}$ \\
$1 \mu \mathrm{l}$ & Template bzw. Wasser & $0-10^{7}$ Moleküle $/ 50 \mu \mathrm{l}$ \\
$\sum 50,0 \mu \mathrm{l}$ & & \\
\hline
\end{tabular}

Das Magnesiumacetat wurde zunächst als adhärenter Tropfen in die Deckel der Reaktionsgefäße gegeben. Als Template wurde je $1 \mu \mathrm{l}$ des quantiativen DNS-Standards,

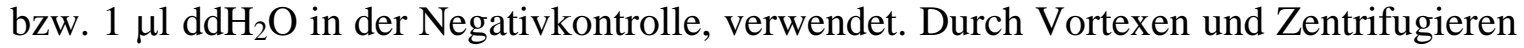
wurde das Magnesiumacetat mit den Proben gemischt und so die Reaktion simultan in allen Reaktionsgefäßen gestartet (Mg-Start). Die Fluoreszenz wurde in einem ESEQuant Tube Scanner für 20 Minuten bei $42^{\circ} \mathrm{C}$ gemessen. Nach 320 Sekunden wurde die Probe durch Vortexen und Zentrifugieren kurz agitiert.

\subsubsection{RT-RPA (RNS)}

Bei der Rekombinase-Polymerase-Amplifikation viraler RNS wurde analog zum Nachweis von DNS (Kapitel 2.2.3.1) vorgegangen. Es wurden lediglich Reverse Transkriptase (Roche), DTT und RNase-Inhibitor dem Reaktionsansatz hinzugefügt. Die 
im Ansatz enthaltenen RPA-Primer dienten dabei auch als Primer für die reverse Transkription.

Ein typischer $50 \mu \mathrm{l}$-Reaktionsansatz enthielt:

\begin{tabular}{lll}
\hline Volumen & & Endkonzentration \\
\hline $2,1 \mu \mathrm{l}$ & Primer A $(10 \mu \mathrm{M})$ & $420 \mathrm{nM}$ \\
$2,1 \mu \mathrm{l}$ & Primer B $(10 \mu \mathrm{M})$ & $420 \mathrm{nM}$ \\
$0,6 \mu \mathrm{l}$ & exoProbe A $(10 \mu \mathrm{M})$ & $120 \mathrm{nM}$ \\
$29,5 \mu \mathrm{l}$ & Rehydratationspuffer $(1,7 \mathrm{X})$ & $1 \mathrm{X}$ \\
$1,0 \mu \mathrm{l}$ & DTT $(0,1 \mathrm{M})$ & $2 \mathrm{mM}$ \\
$0,5 \mu \mathrm{l}$ & RNaseOut $(40 \mathrm{U} / \mu \mathrm{l})$ & $0,4 \mathrm{U} / \mu \mathrm{l}$ \\
$0,5 \mu \mathrm{l}$ & Reverse Traskripate (Roche) $(20 \mathrm{U} / \mu \mathrm{l})$ & $0,2 \mathrm{U} / \mu \mathrm{l}$ \\
$8,7 \mu \mathrm{l}$ & ddH ${ }_{2} \mathrm{O}$ & \\
$4,0 \mu \mathrm{l}$ & Mg-Acetat $(280 \mathrm{mM})$ & $22,4 \mathrm{mM}$ \\
$1 \mu \mathrm{l}$ & Template bzw. Wasser & $0-10^{7} \mathrm{Moleküle} / 50 \mu \mathrm{l}$ \\
$\sum 50,0 \mu \mathrm{l}$ & & \\
\hline
\end{tabular}

\subsubsection{Statistische Auswertung}

\subsubsection{Das Probit-Modell}

Da die gemessenen Werte einen binären Charakter aufweisen (die Reaktion ist entweder positiv oder negativ), ist eine statistische Annäherung an das Verhalten der einzelnen Reaktionen durch lineare Regression nicht möglich. Deshalb wurde zur mathematischen Charakterisierung das sogenannte Probit-Modell gewählt (McCulloch und Searle 2001, S. 135). Das Probit-Modell beschreibt, analog zur Methode der kleinsten Quadrate, den Zusammenhang zwischen dem Anteil der positiven Tests und der Anzahl der eingesetzten Moleküle, indem eine Kurve mit der S-förmigen Form der Verteilungsfunktion einer Gauß'schen Normalverteilung $\phi$ gestreckt und verschoben an die gemessenen Daten 
angepasst wird. Die Kurve der Funktion $\mathrm{P}=\phi\left(\mathrm{a}^{*} \mathrm{x}+\mathrm{b}\right)$ wird so modelliert, dass die quadrierte Differenz der vorhergesagten Werte zu den gemessenen Werten (Residuum) möglichst klein ist. $P$ ist die Wahrscheinlichkeit für ein positives Testergebnis, $a$ gibt an, wie steil die Kurve verläuft und $b$ verschiebt die Kurve auf der Abszissenachse.

In einem zweiten Schritt wird auf Grundlage der modellierten Kurve ein Erwartungswert geschätzt, bei welchem 95\% der Testläufe positiv sind. Es handelt sich bei den durch die Probitanalyse gewonnenen Schwellenwerten der Sensitivität der einzelnen Reaktionen also um statistische Schätzwerte, welche die theoretische Molekülanzahl angeben, bei welcher, auf Grundlage der durchgeführten Messungen, 95\% der Testläufe ein positives Ergebnis zeigen. 


\section{Ergebnisse}

\subsection{Rekombinase-Polymerase-Amplifikation von viraler RNS}

\subsubsection{Rekombinase-Polymerase-Amplifikation von Influenza-A-Virus}

\subsubsection{Entwurf des Amplikons für den Nachweis von Influenza-A-Virus}

Zum Entwurf des Influenza-A-Virus-Amplikons wurden mehrere zufällig gewählte Nukleinsäuresequenzen des Matrixprotein-Gens auf Segment 7 des Influenza-A-Virus aus der öffentlich zugänglichen Datenbank GenBank (www.ncbi.nlm.nih.gov/genbank/) verwendet. Anhand von bereits veröffentlichten Amplikons zum Nachweis von InfluenzaA mittels Echtzeit-RT-PCR (z. B. Spackman et al. 2002) wurden konservierte Regionen des viralen Genoms eingegrenzt, welche potentielle Ziele für den RPA-Nachweis darstellen. Durch ein Alignment der einzelnen Sequenzen wurden diese Zielregionen erneut auf ihren Konservierungsgrad und damit auf ihre Eignung für die RPA überprüft (vergl. Abb. 6.1, Anhang).

Da der Prozess der Rekombinase-Polymerase-Amplifikation noch nicht in allen Details verstanden wird, ist es unmöglich, eine genaue Prognose über die Funktionalität eines gegebenen Primerpaares zu treffen. Daher muss der Entwurf der Oligonukleotide in Form eines „Versuch-und-Irrtum“-Ansatzes erfolgen. Als Richtlinien für das Primerdesign können lediglich einige Erfahrungswerte dienen, die der Hersteller des RPA Reagenziensatzes angibt. Die verwendeten Oligonukleotide sollten eine Länge von 30-35 nt aufweisen. Das bedeutet, dass PCR-Primer in der Regel nicht für RPA-Reaktionen verwendet werden können, aber andererseits RPA-Primer durchaus als PCR-Primer geeignet sind. Außerdem sind RPA-Primer ebenfalls als spezifische Primer für die reverse Transkription verwendbar. Ungewöhnliche Sequenzen und ein großer Guaningehalt am 5'-Ende des Oligonukleotids sollten vermieden werden. Ein C- und G-reiches 3'-Ende scheint die Leistung der Reaktion zu verbessern. Der CG-Gehalt des Oligonucleotids sollte zwischen 30 und 70\% liegen und das Amplifikationsprodukt sollte idealerweise eine Länge von 100 bis 200 bp haben.

Nach diesen Kriterien wurden anhand des Alignments insgesamt 14 Primerkandidaten und eine Fluoreszenzsonde entworfen. Dabei wurde ein möglichst großer Bereich der 
konservierten Regionen des Influenza-A-Virus abgedeckt, um eventuelle hinderliche Faktoren, wie Sekundärstrukturbildung oder Probleme bei der Stranginvasion durch die Rekombinase, frühzeitig auszuschließen.

\subsubsection{Herstellung synthetischer Influenza-A-Standard-RNS}

Zur Herstellung der synthetischen Influenza-A-Standard-RNS wurden zunächst die Nukleinsäuren aus einem Zellkulturüberstand extrahiert (Kapitel 2.2.1.1). Die darin enthaltene virale RNS wurde mithilfe von reverser Transkriptase enzymatisch in Komplementär-DNS umgeschrieben (Kapitel 2.2.1.2). Daraufhin wurde die cDNS des Segmentes 7 mittels spezifischer PCR amplifiziert (Primer: FluA S7for, FluA S7rev, Kapitel 2.2.1.3). Das Amplifikationsprodukt wurde durch eine analytische AgarosegelElektrophorese analysiert (Kapitel 2.2.1.4). Diese ergab, wie erwartet, eine einzige Bande bei ca 1000 bp, welche der amplifizierten cDNS des Segmentes 7 entspricht.

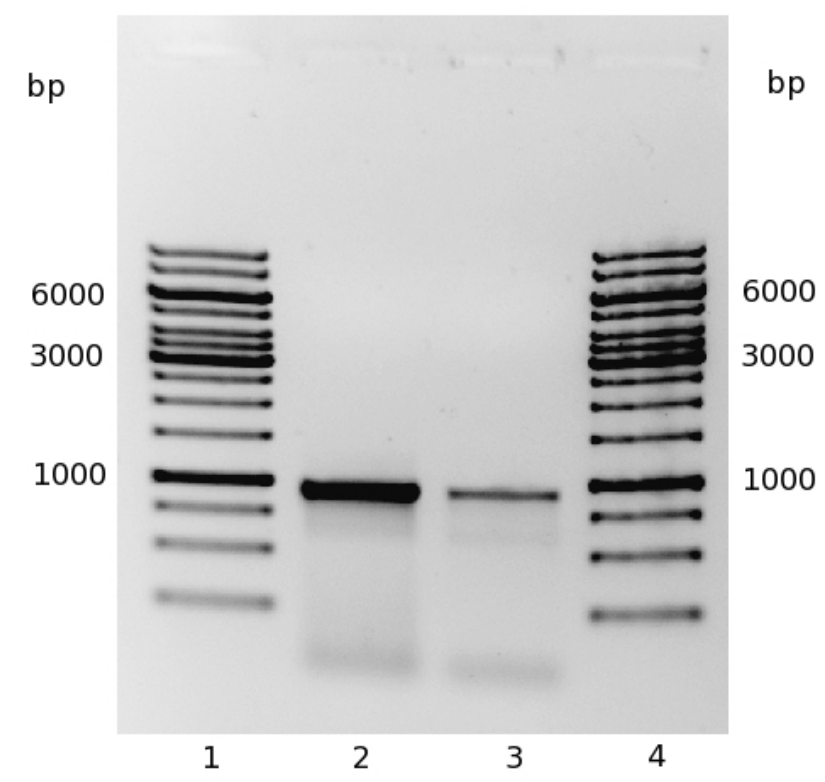

Abb. 3.1: $\quad$ Agarosegel-Elektrophorese des amplifizierten Segmentes 7 von Influenza-A-Virus.

Es wurden pro Spur jeweils 2,5 $\mu$ l DNS-Längenstandard (1 kb) bzw. $5 \mu$ l PCR-Produkt eingesetzt. Spur 1 und 4 enthalten die Längenstandards, Spur 2 enthält einen PCR-Ansatz aus ca. 10 ng cDNS. Spur 3 enthält einen PCR-Ansatz aus ca 1 ng cDNS. 
Zur dauerhaften Sicherung der DNS-Sequenz wurde diese in ein ringförmiges pCRII ${ }^{\circledR}$ Plasmid integriert, welches durch chemisch kompetente E. coli-Bakterien aufgenommen und dann beliebig vermehrt werden kann (TA-Klonierung). Dazu wurde zunächst das PCR-Produkt, welches aufgrund der verwendeten Polymerase einen A-Überhang am 3'Ende aufweist, mit linearem Plasmid und einer Ligase über Nacht inkubiert (Kapitel 2.2.1.6). Es wurden 8 weiße Klone (keine Laktaseaktivität) ausgewählt und in Flüssigmedium überführt. Der Erfolg der Transformation wurde durch DNSMinipräparation (Kapitel 2.2.1.11) und anschließenden Restriktionsverdau mit dem Enzym EcoRI (Kapitel 2.2.1.12) überprüft. Da der pCRII®-Vektor direkt vor und hinter der multiplen Klonierungsstelle eine entsprechende Schnittstelle besitzt, (vergl. Abb. 2.1) sollte im Falle einer erfolgreichen Transformation eine Bande in der Größe des Inserts (ca. $1 \mathrm{~kb}$ ) und eine zweite Bande in Größe des Vektors (ca $4 \mathrm{~kb}$ ) nachweisbar sein. Dies war bei den Bakterienklonen 1 und 2 sowie 4 bis 7 der Fall (Abb. 3.2). Aus der Flüssigkultur des Bakterienklons 1 wurde eine Dauerkultur angelegt (Kapitel 2.2.1.10).

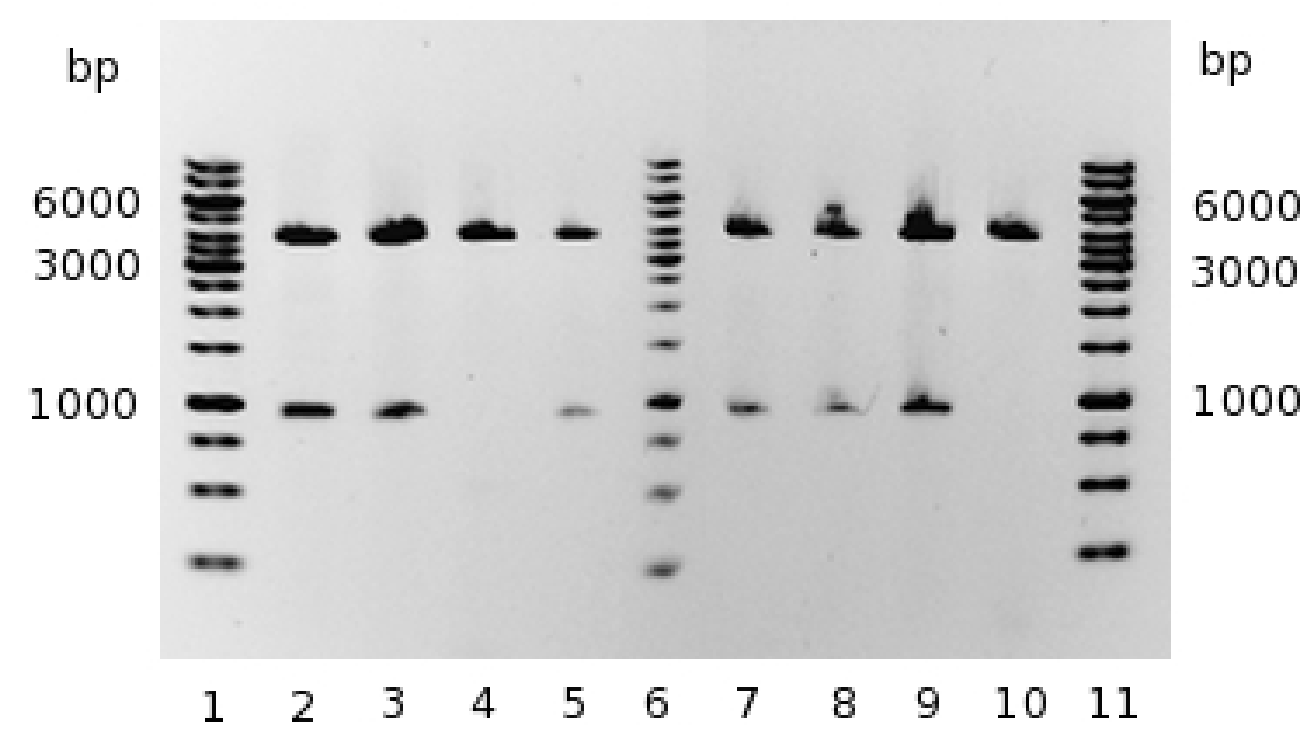

Abb. 3.2: $\quad$ Analytischer EcoRI-Verdau der Plasmid-DNS der Influenza-A-Bakterienklone. Es wurden pro Spur jeweils 2,5 $\mu$ l DNS-Längenstandard (1 kb) bzw. $10 \mu$ l Plasmid-DNS eingesetzt. Spur 1, 6 und 11 enthalten die Längenstandards, die Spuren 2 bis 5 sowie 7 bis 10 enthalten verdaute Plasmid-DNS. Die Klone 1 und 2 sowie 4 bis 7 zeigen die erwartete Insert-Bande bei ca $1 \mathrm{~kb}$. Die Klone 3 und 8 zeigen lediglich eine Bande in Größe des Vektors. 
Aus der durch DNS-Minipräparation gewonnenen Plasmid-DNS von Klon 1 wurde mittels M13-PCR (siehe Kapitel 2) das Insert, und die flankierenden im Vektor enthaltenen Promotoren SP6 und T7 amplifiziert.

Um das Insert genauer zu charakterisieren, wurde eine Sequenzierung mit M13for Primer durchgeführt (Kapitel 2.2.1.14). Eine BLAST-Analyse ergab eine hundertprozentige Übereinstimmung mit dem Matrixprotein-Gen des Influenza-A Stammes A/Illinois/NHRC0001/2011(H1N1) (GenBank Nr. CY092873).

Das M13-PCR Fragment zeigte eine Negativstrangorientierung des Inserts und wurde einer Transkription mit SP6-RNA-Polymerase zugeführt (Kapitel 2.2.1.15). Diese erzeugt aus der DNS-Vorlage synthetische, weitgehend dem viralen Segment 7 entsprechende, RNS. Die im Ansatz enthaltene DNS wurde durch viermalige DNase-Behandlung entfernt (Kapitel 2.2.1.16). Danach wurde das Mengenverhältnis von Rest-DNS zur erwünschten RNS durch einen Vergleich von Echtzeit-PCR (DNS) und Echtzeit-RT-PCR (RNS und DNS) bestimmt (Kapitel 2.2.2.5 f., Primer: InfA for, InfA rev, Sonde: InfA Probe). Bei einem Signalabstand von 23 Thermozyklen wurde davon ausgegangen, dass in den relevanten Verdünnungsstufen der synthetischen Standards keine nachweisbare Rest-DNS enthalten ist. Zur genauen Quantifizierung der Standard-RNS wurde eine photometrische Messung mit dem Fluoreszenzfarbstoff RiboGreen ${ }^{\circledR}$ durchgeführt (Kapitel 2.2.2.3). Diese ergab eine RNS-Konzentration von 152,73 ng/ $\mu \mathrm{l}$. Bei einer theoretischen Größe des RNS-Fragmentes von 1135 nt einzelsträngiger RNS entspricht das 2,46 x $10^{11}$ Molekülen/ $\mu$ l (Kapitel 2.2.2.4). Von dieser Konzentration ausgehend wurden Standardverdünnungen mit 10 bis $10^{7}$ Molekülen / $\mu$ l angelegt. Die quantitativen RNSStandards wurden bei $-80^{\circ} \mathrm{C}$ gelagert. Die Qualität der Standardreihe wurde durch Echtzeit-RT-PCR überprüft (Primer: InfA for, InfA rev, Sonde: InfA Probe). 


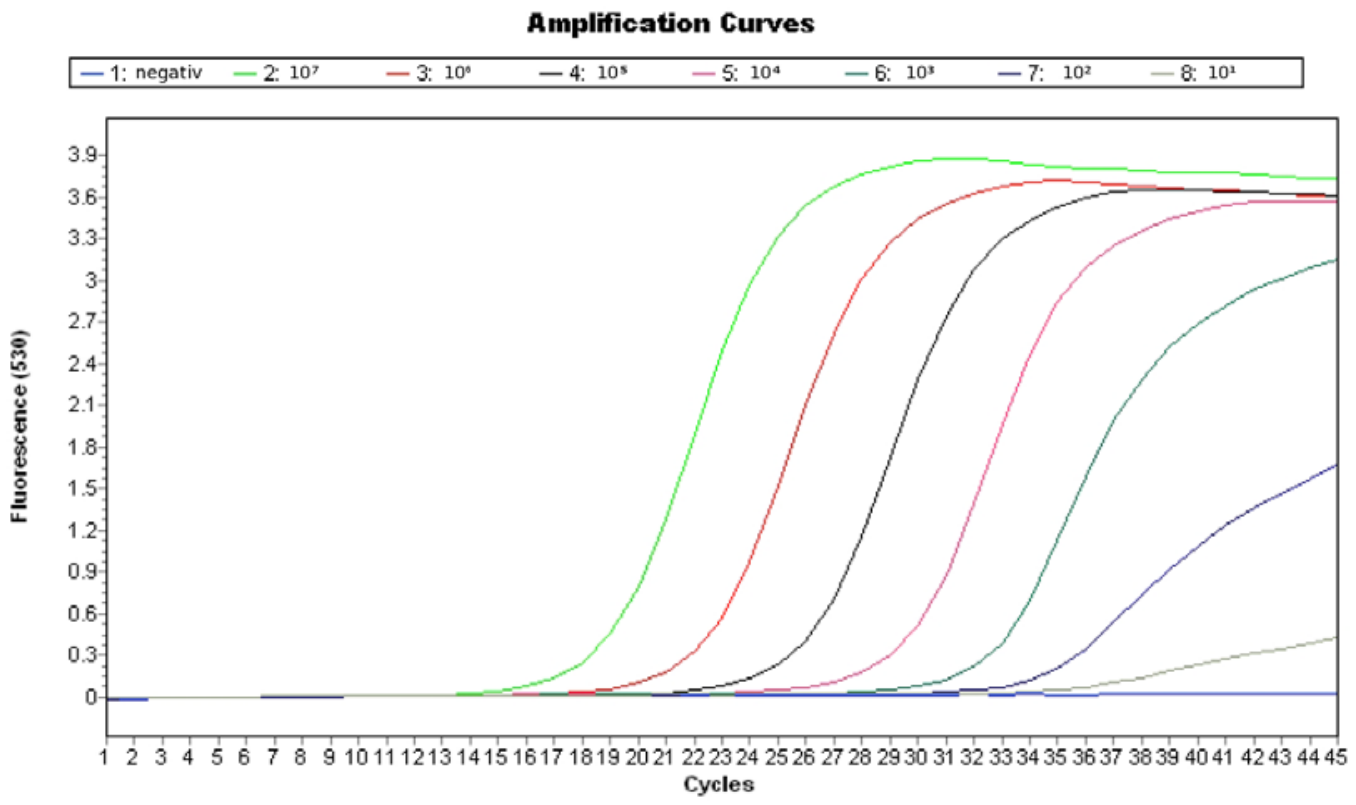

Abb. 3.3: $\quad$ Echtzeit RT-PCR Messung der synthetischen Influenza-A-Standardreihe.

Es wurde in jeden Ansatz eine definierte Menge Standard-RNS gegeben. Die Reaktion zeigt nach 35 Thermozyklen eine Sensitivität von bis $\mathrm{zu} 10$ Molekülen. Als Negativkontrolle wurde $\mathrm{ddH}_{2} \mathrm{O}$ eingesetzt.

Die Echtzeit-RT-PCR-Messung wurde insgesamt drei Mal durchgeführt und durch Mittelwertbildung eine Standardgerade ermittelt.

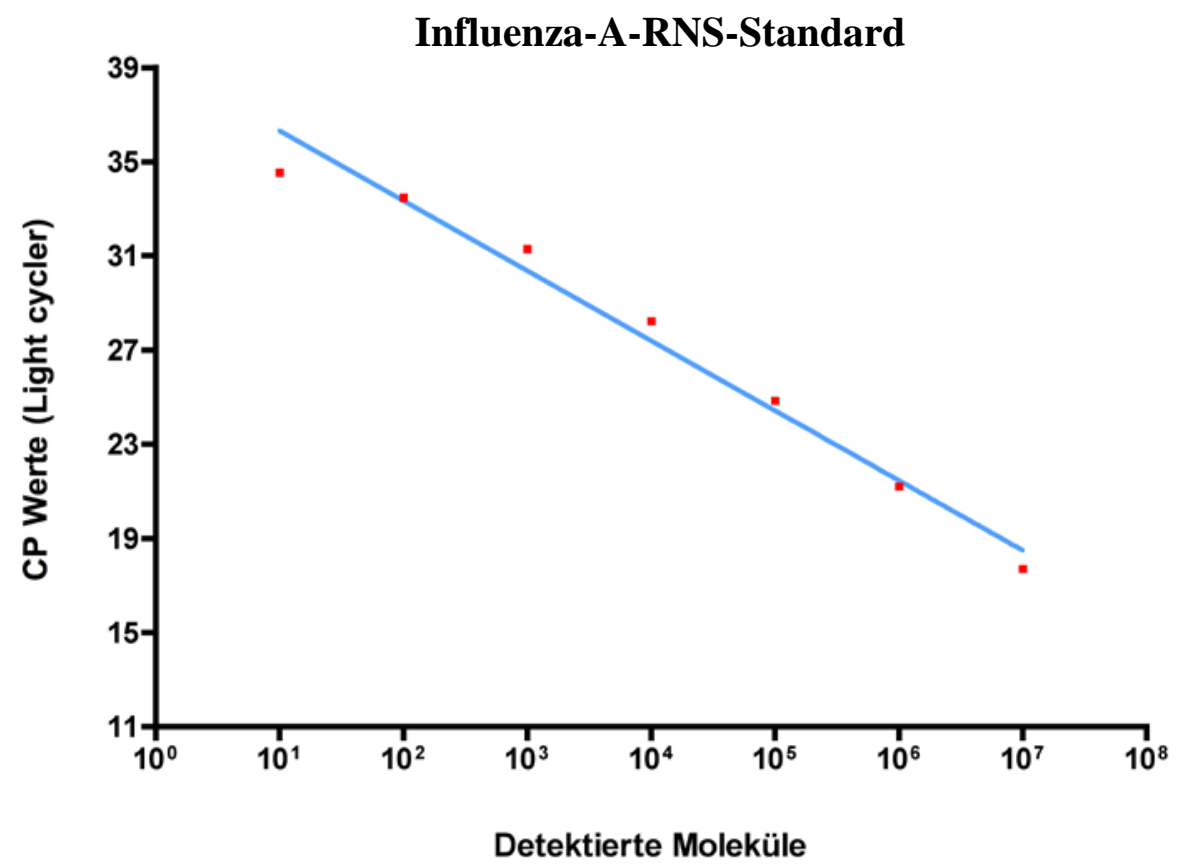

Abb. 3.4: Influenza-A-Standardkurve ermittelt durch drei Echtzeit-RT-PCR-Läufe.

Auf der Abszisse ist die Anzahl der detektierten Moleküle, auf der Ordinate die Anzahl der Thermozyklen, die zum Erreichen eines Signals notwendig waren, aufgetragen. 


\subsubsection{Evaluation der Influenza-A-RPA-Primerkandidaten}

Die Evaluation der 14 RPA-Primerkandidaten erfolgte unter Anwesenheit von $10^{5}$ Molekülen Standard-RNS durch Einsetzen eines Vorwärtsprimers und verschiedener Rückwärtsprimer (Kapitel 2.2.3.2). Der Rückwärtsprimer, der das beste Signal ergab, wurde in einem weiteren Schritt gegen verschiedene Vorwärtsprimer getestet. Das so ermittelte optimale Primerpaar wurde für die weiteren Messungen verwendet.

\subsubsection{Analytische Sensitivität der Influenza-A-RT-RPA}

Zur Ermittlung der analytischen Sensitivität der Influenza-A-RT-RPA-Reaktion wurden die verschiedenen Konzentrationen der synthetischen Standard-RNS mit dem zuvor ermittelten Primerpaar FluA UP und FluA DP sowie der Fluoreszenzsonde FluA Exo Probe eingesetzt.

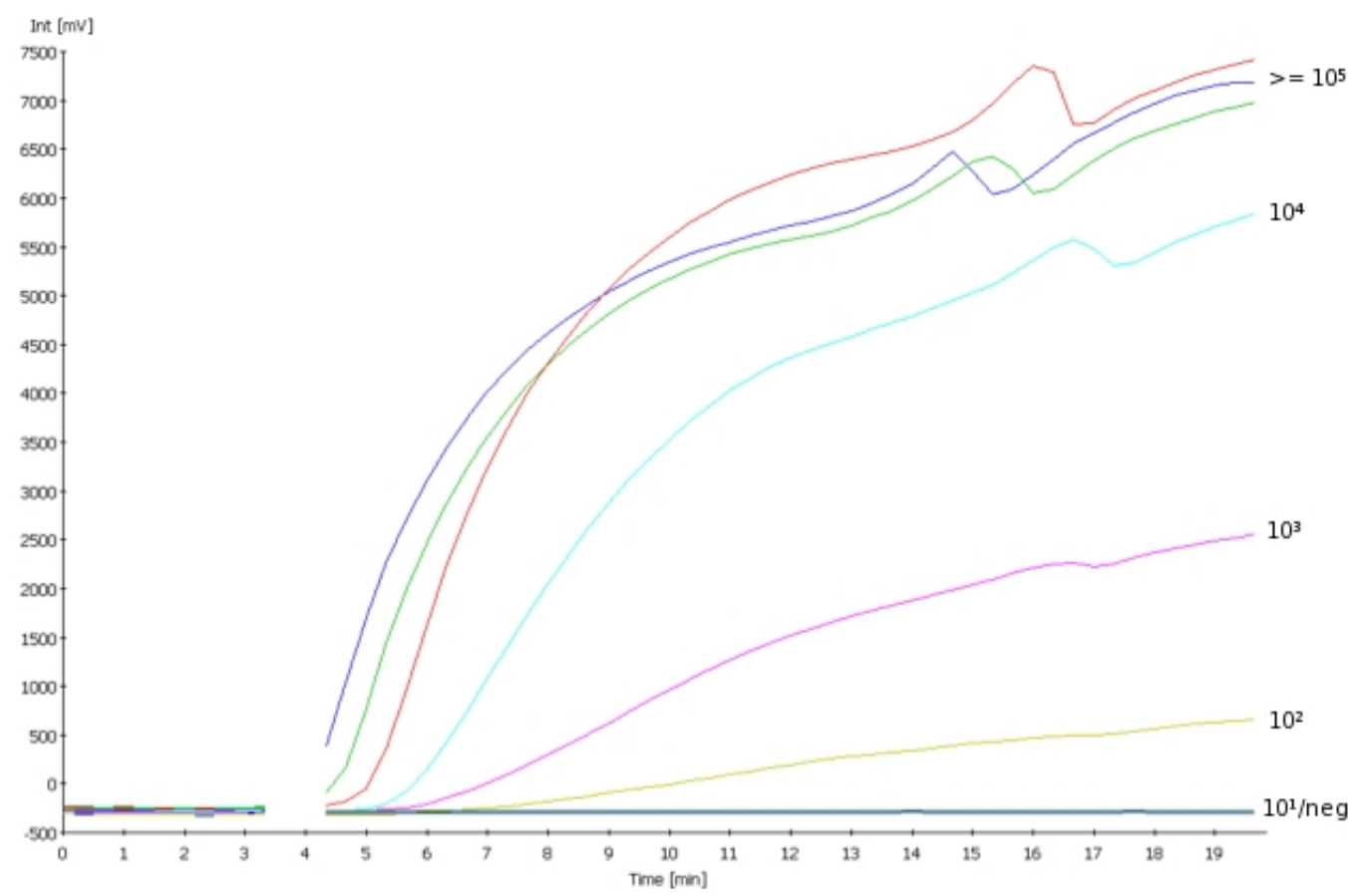

Abb. 3.5: Influenza-A-RT-RPA.

Auf der Abszisse ist die Reaktionsdauer in Minuten, auf der Ordinate die Stärke des Fluoreszenzsignals in $\mathrm{mV}$ aufgetragen. Die Reaktion detektiert bis zu $10^{2}$ Moleküle in weniger als 10 Minuten. Die Negativkontrolle und der $10^{1}$ Standard zeigen kein Signal. 


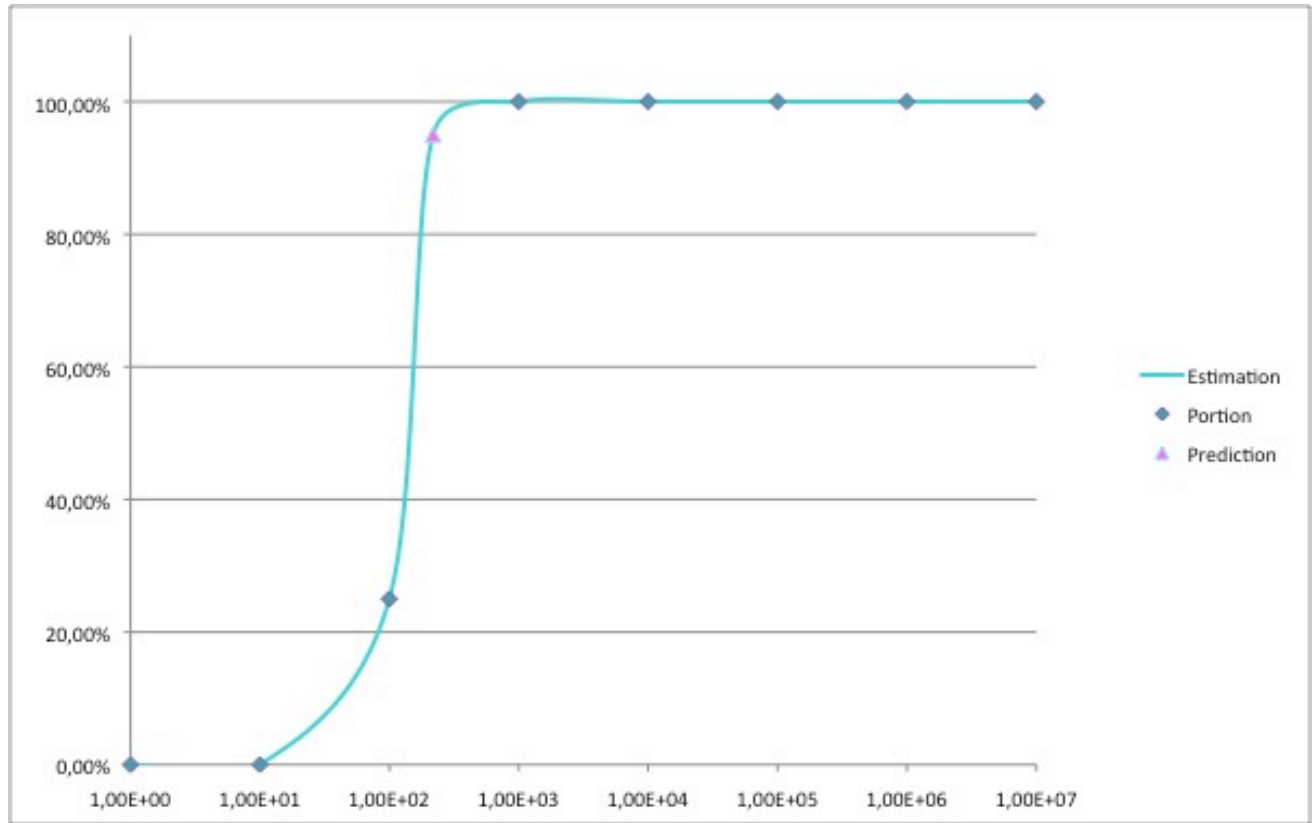

Abb. 3.6: Probit-Analyse der Sensitivität der Influenza-A-RT-RPA.

Auf Grundlage der acht durchgeführten Läufe werden theoretisch in 95\% der Testläufe 218 Moleküle im Reaktionsansatz nachgewiesen.

Die Messung wurde jeweils acht Mal in gleicher Form ausgeführt, um mittels statistischer Probit-Analyse eine Aussage über die theoretische Anzahl von Molekülen treffen zu können, die benötigt wird, um ein positives Testergebnis zu erzielen. Diese Auswertung ergab, dass die entwickelte Influenza-A-Reaktion theoretisch in der Lage ist, in 95\% der Testläufe 218 Moleküle viraler RNS in einem $50 \mu$ l-Reaktionsansatz in weniger als 9 Minuten nachzuweisen (vergleiche Tabelle 3.1). 


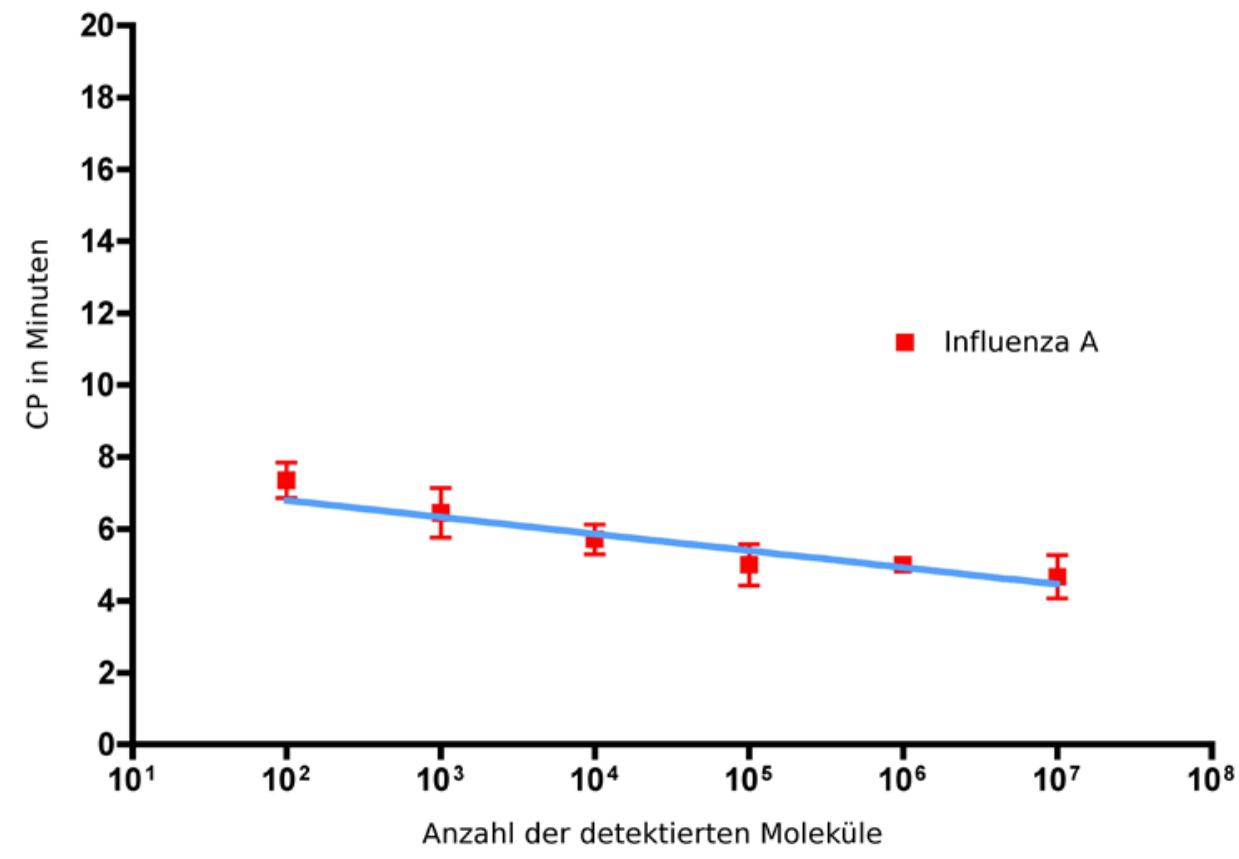

Abb. 3.7: Standardkurve der Influenza-A-RT-RPA Reaktionsgeschwindigkeit.

Die Grafik zeigt die Regressionsgerade berechnet aus den Ergebnissen von 8 RT-RPADurchläufen mit dem quantitativen molekularen Standard. Die Influenza-A-Reaktion benötigt weniger als 9 Minuten, um bis zu $10^{2}$ Moleküle in $50 \mu l$ nachzuweisen.

Tabelle 3.1 Sensitivität der Influenza-A-RPA- und Echtzeit-PCR-Assays im Vergleich.

* Nachgewiesene Moleküle in $50 \mu \mathrm{l}$

\begin{tabular}{|ccccc|}
\hline Erreger und Zielgen & $\begin{array}{c}\text { Sensitivität* } \\
\text { Echtzeit-PCR }\end{array}$ & $\begin{array}{c}\text { Sensitivität* } \\
\text { RPA }\end{array}$ & $\begin{array}{c}\text { Probit Sensitivität* } \\
\text { (95\%) RPA }\end{array}$ & $\begin{array}{c}\text { Laufzeit } \\
\text { (min) }\end{array}$ \\
& 3 Läufe & $\mathbf{8}$ Läufe & $\mathbf{8}$ Läufe & \\
\hline Influenza-A-Virus (M) & $10^{1}-10^{2}$ & $10^{2}-10^{3}$ & 218 & 8 \\
\hline
\end{tabular}

\subsubsection{Analytische Spezifität der Influenza-A-RPA}

Zur Überprüfung der analytischen Spezifität bzw. eventueller Kreuzreaktivität wurden sowohl genomische RNS von Influenza-B-Virus als auch DNS der Adenovirus-Serotypen 1, 4 und 7 in die Influenza-A-Reaktion eingesetzt. Dabei konnte keine Kreuzreaktivität nachgewiesen werden. 


\subsubsection{Rekombinase-Polymerase-Amplifikation von Influneza-B-Virus}

\subsubsection{Entwurf des Amplikons für den Nachweis von Influenza-B-Virus}

Zum Entwurf des Influenza-B-Amplikons wurde eine konservierte Region des Hämagglutinin-Gens auf Segment 4 des viralen Genoms gewählt. Analog zum Vorgehen beim Influneza-A-Amplikon (Kapitel 3.1.1.1) wurden mehrere zufällig gewählte GenBank-Sequenzen dieser Region mittels Alignment auf ihren Konservierungsgrad geprüft. Ausgehend von diesem Alignment wurden 24 Primerkandidaten und eine Fluoreszenzsonde entworfen (vergl. Abb. 6.2, Anhang).

\subsubsection{Herstellung synthetischer Influenza-B-Standard-RNS}

Zur Produktion von synthetischer Influenza-B-RNS wurde eine vorhandene, in pCRIIVektor gesicherte Sequenz verwendet. Diese Sequenz wurde mittels PCR (Primer: M13 For, M13 Rev) amplifiziert, um sowohl die eingefügte virale Sequenz als auch die auf dem Vektor enthaltenen T7- und SP6- Promotoren zu erhalten.

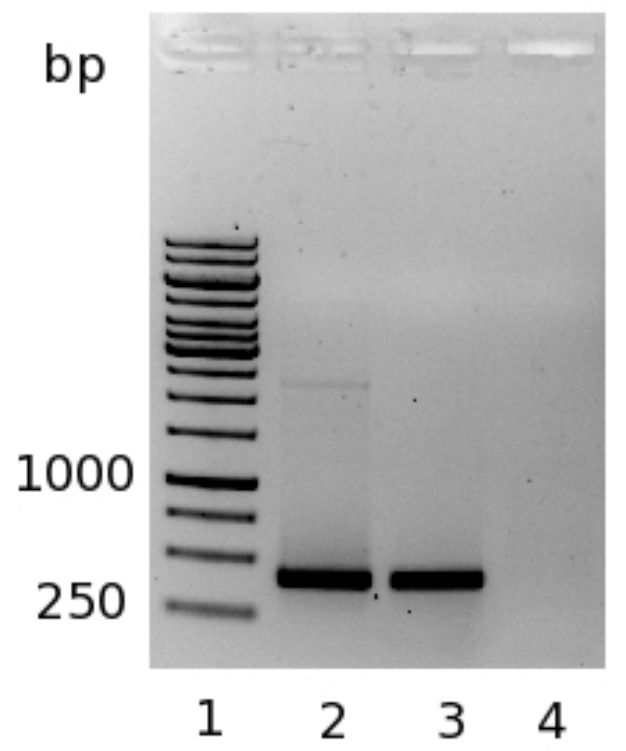

Abb. 3.8: Influenza-B-M13-PCR-Produkt.

Es wurden pro Spur jeweils 2,5 $\mu \mathrm{l}$ DNS-Längenstandard (1 kb) bzw. $5 \mu \mathrm{l}$ PCR-Produkt eingesetzt. Spur 1 enthält den Längenstandard, Spur 2 enthält einen PCR-Ansatz aus ca. 40 ng Plasmid-DNS. Spur 3 enthält einen PCR-Ansatz aus ca 4 ng Plasmid-DNS. Spur 4 enthält die Negativkontrolle. Beide PCR-Ansätze zeigen die erwartete Bande bei ca. 400 bp.

Das M13-PCR-Fragment wurde verwendet, um, bei Positivstrangorientierung des Inserts, eine Transkription mit T7-RNS-Polymerase durchzuführen (Kapitel 2.2.1.15, S. 35). 
Diese erzeugt aus der DNS-Vorlage synthetische RNS, welche einem 358 nt langen Abschnitt des viralen Hämagglutinin-Gens entspricht. Die im Ansatz enthaltene DNS wurde durch dreimalige DNase-Behandlung entfernt (Kapitel 2.2.1.16). Danach wurde das Mengenverhältnis von Rest-DNS zur erwünschten RNS durch einen Vergleich von Echtzeit-PCR (DNS) und Echtzeit-RT-PCR (RNS und DNS) bestimmt (Kapitel 2.2.2.5 f., Primer: FluB FP, FluB RP, Sonde: FluB P). Bei einem Signalabstand von 24 Thermozyklen wurde davon ausgegangen, dass in den relevanten Verdünnungsstufen der synthetischen Standards keine nachweisbare Rest-DNS enthalten ist. Zur genauen Quantifizierung der Standard-RNS wurde eine photometrische Messung mit dem Fluoreszenzfarbstoff RiboGreen ${ }^{\circledR}$ durchgeführt (Kapitel 2.2.2.3). Diese ergab eine RNSKonzentration von $404 \mathrm{ng} / \mu \mathrm{l}$. Bei einer theoretischen Größe des RNS-Fragmentes von 358 nt einzelsträngiger RNS entspricht das 2,06 x $10^{12}$ Molekülen/ $\mu \mathrm{l}$ (Kapitel 2.2.2.4). Von dieser Konzentration ausgehend wurden Standardverdünnungen mit 10 bis $10^{7}$ Molekülen $/ \mu \mathrm{l}$ angelegt. Die quantitativen RNS-Standards wurden bei $-80^{\circ} \mathrm{C}$ gelagert. Die Qualität der Standardreihe wurde durch Echtzeit-RT-PCR überprüft (Primer: FluB FP, FluB RP, Sonde: FluB P).

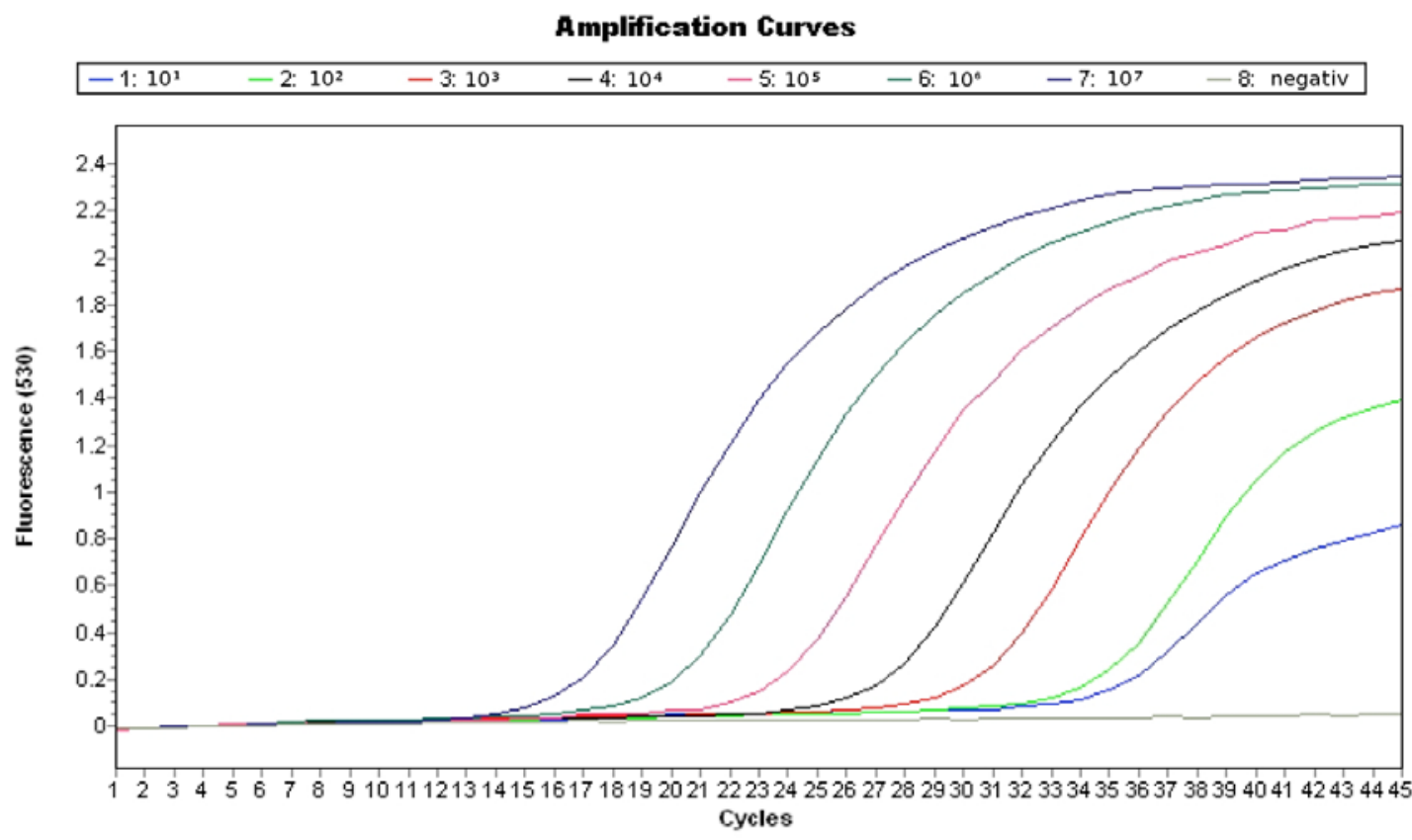

Abb. 3.9: $\quad$ Echtzeit-RT-PCR-Messung der synthetischen Influenza-B-Standardreihe. Es wurde in jeden Ansatz eine definierte Menge Standard-RNS gegeben. Die Reaktion zeigt nach 35 Thermozyklen eine Sensitivität von bis zu 10 Molekülen. Als Negativkontrolle wurde $\mathrm{ddH}_{2} \mathrm{O}$ eingesetzt. 
Die Echtzeit-RT-PCR-Messung wurde insgesamt drei Mal durchgeführt und durch Mittelwertbildung eine Standardgerade ermittelt.

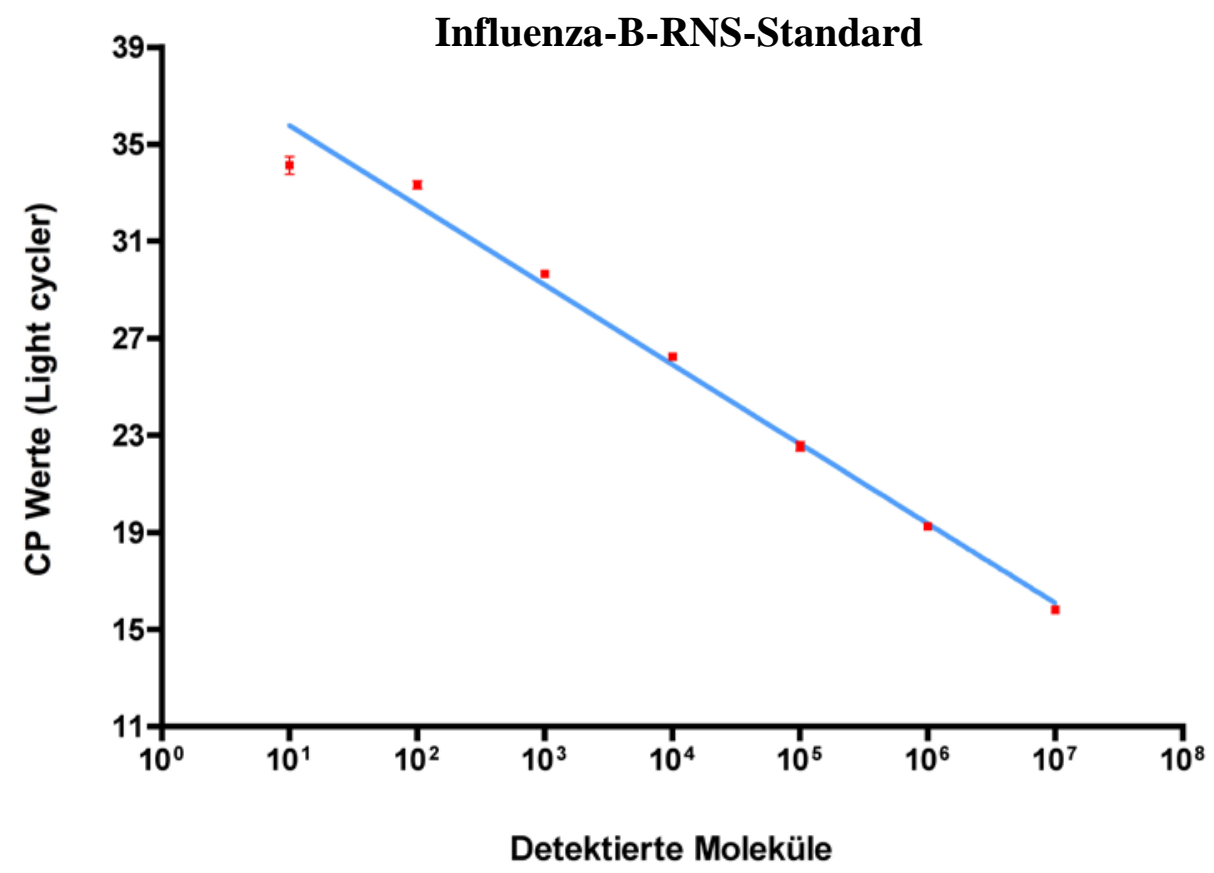

Abb. 3.10: Influenza-B-Standardkurve ermittelt durch drei Echtzeit-RT-PCR-Läufe.

Auf der Abszisse ist die Anzahl der detektierten Moleküle, auf der Ordinate die Anzahl der Thermozyklen, die zum Erreichen eines Signals notwendig waren, aufgetragen.

\subsubsection{Evaluation der Influenza-B-RPA-Primerkandidaten}

Die Evaluation der 24 RPA-Primerkandidaten erfolgte unter Anwesenheit von $10^{5}$ Molekülen Standard-RNS und der Fluoreszenzsonde FluB exoProbe. Durch Einsetzen eines Vorwärtsprimers und verschiedener Rückwärtsprimer (Kapitel 2.2.3.2) wurde zunächst der beste Rückwärtsprimer bestimmt. Mit diesem wurden in einem weiteren Schritt die verschiedenen Vorwärtsprimer auf ihre Funktion getestet. Die so bestimmte optimale Kombination von FluB UP und FluB DP wurde für die weiteren Reaktionen verwendet.

\subsubsection{Analytische Sensitivität der Influenza-B-RPA}

Zur Evaluation der Influenza-B-RPA wurde die synthetische quantitative Standardreihe mit den Primern FluB UP und FluB DP sowie der Fluoreszenzsonde FluB exoProbe in 
die Reaktion eingesetzt (Kapitel 2.2.3.2). Die Messung wurde zur statistischen Auswertung achtmal in gleicher Form durchgeführt. Die Probit-Analyse ergab, dass theoretisch 132 Moleküle virale RNS in einem $50 \mu$ l-Reaktionsansatz enthalten sein müssen, um in 95\% der Testläufe in weniger als 9 Minuten ein positives Ergebnis zu erzielen (vergleiche Tabelle 3.2).

Tabelle 3.2 Sensitivität der Influenza-B-RPA- und Echtzeit-PCR-Assays im Vergleich.

* Nachgewiesene Moleküle in $50 \mu \mathrm{l}$

\begin{tabular}{|ccccc|}
\hline Erreger und Zielgen & $\begin{array}{c}\text { Sensitivität* } \\
\text { Echtzeit-PCR }\end{array}$ & $\begin{array}{c}\text { Sensitivität* } \\
\text { RPA }\end{array}$ & $\begin{array}{c}\text { Probit Sensitivität* } \\
\text { (95\%) RPA }\end{array}$ & $\begin{array}{c}\text { Laufzeit } \\
\text { (min) }\end{array}$ \\
& 3 Läufe & $\mathbf{8}$ Läufe & $\mathbf{8}$ Läufe & \\
\hline Influenza-B-Virus (HA) & $10^{1}-10^{2}$ & $10^{2}-10^{3}$ & 131 & 8 \\
\hline
\end{tabular}

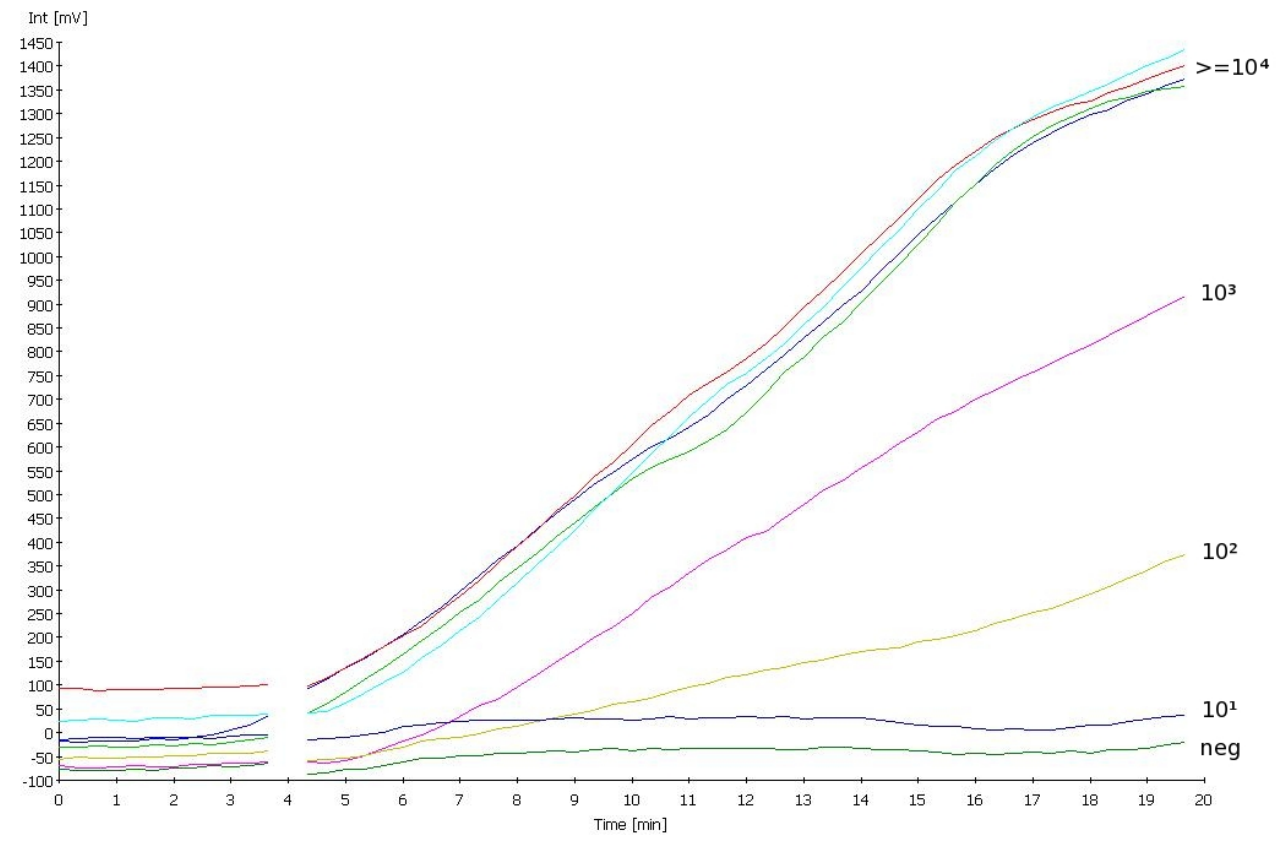

Abb. 3.11: Influenza-B-RT-RPA.

Auf der Abszisse ist die Reaktionsdauer in Minuten, auf der Ordinate die Stärke des Fluoreszenzsignals in mV aufgetragen. Die Reaktion detektiert bis zu $10^{2}$ Moleküle in weniger als 10 Minuten. Die Negativkontrolle und der $10^{1}$-Standard zeigen kein Signal. 


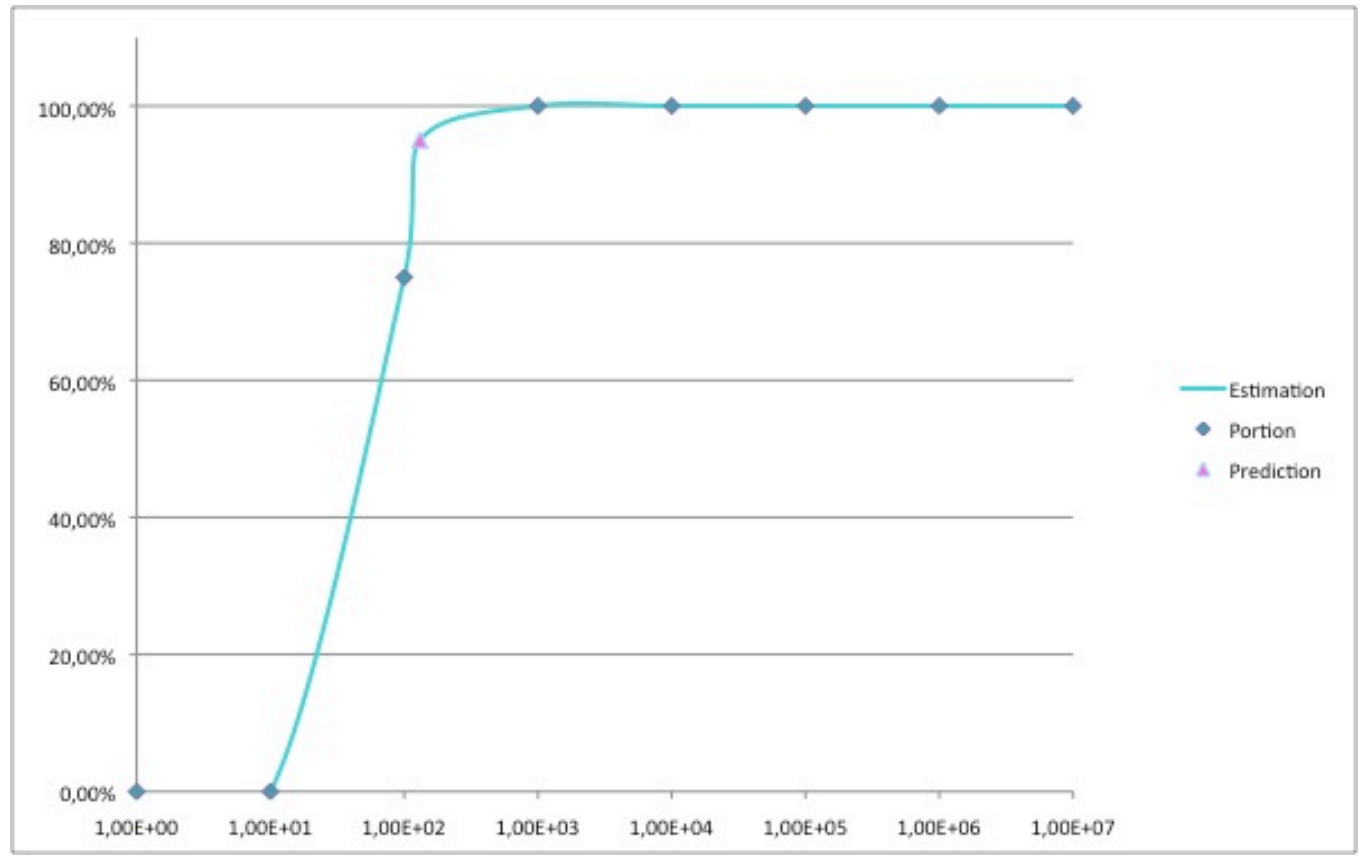

Abb. 3.12: Probit-Analyse der Sensitivität der Influenza-B-RT-RPA.

Auf Grundlage der acht durchgeführten Läufe werden theoretisch in 95\% der Testläufe 132 Moleküle im Reaktionsansatz nachgewiesen.

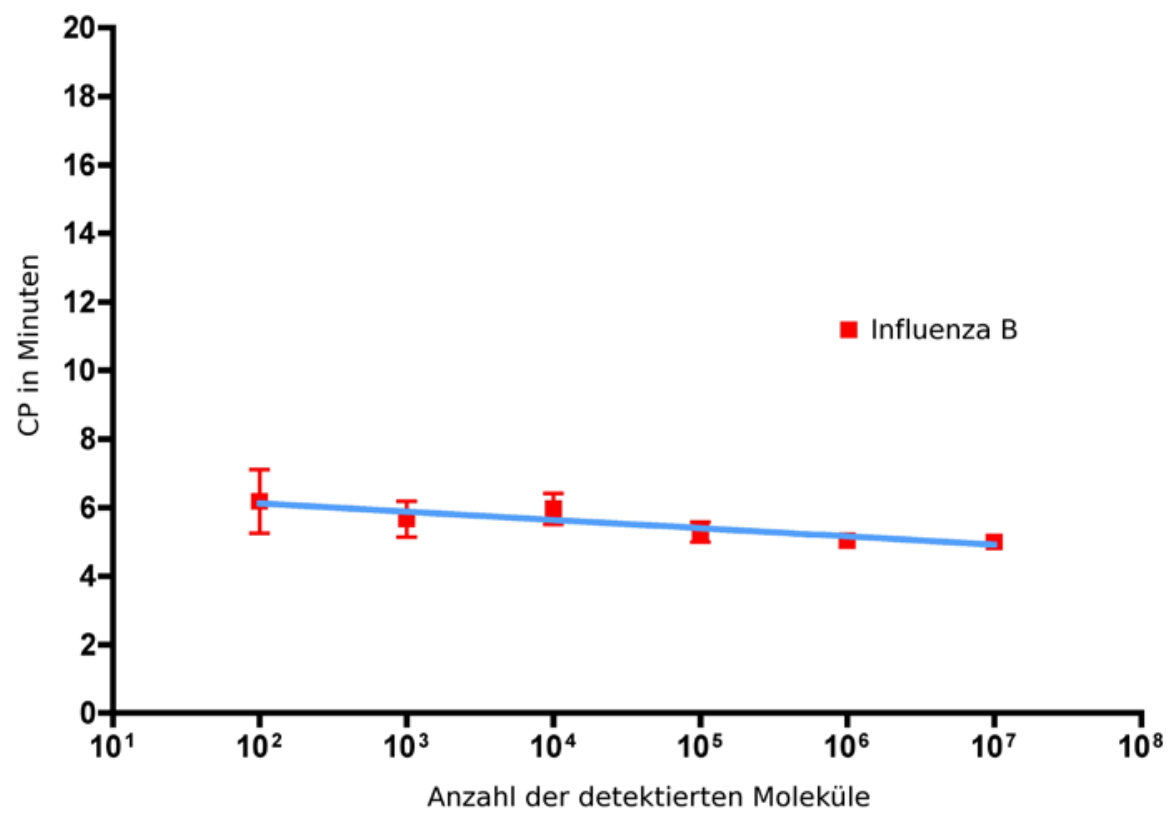

Abb. 3.13: Standardkurve der Reaktionsgeschwindigkeit der Influenza-B-RT-RPA.

Die Grafik zeigt die Regressionsgerade, berechnet aus den Ergebnissen von 8 RT-RPADurchläufen mit dem quantitativen molekularen Standard. Die Influenza-B-Reaktion benötigt weniger als 9 Minuten, um bis zu $10^{2}$ Moleküle in $50 \mu$ nachzuweisen 


\subsubsection{Analytische Spezifität der Influenza-B-RPA}

Zur Überprüfung der analytischen Spezifität bzw. eventueller Kreuzreaktivität wurden sowohl genomische RNS von Influenza-A-Virus als auch DNS der Adenovirus Serotypen 1, 4 und 7 in die Influenza-B-Reaktion eingesetzt. Dabei konnte keine Kreuzreaktivität nachgewiesen werden.

\subsection{Rekombinase-Polymerase-Amplifikation von viraler DNS}

\subsubsection{Rekombinase-Polymerase-Amplifikation humaner Adenoviren}

\subsubsection{Entwurf der Amplikons für den Nachweis humaner Adenoviren}

Die humanen Adenoviren sind eine sehr heterogene Gruppe von Viren. Es sind derzeit 57 Serotypen bekannt. Die aus der Literatur zu entnehmenden Echtzeit-PCR-Reaktionen zum allgemeinen Nachweis aller Adenoviren basieren auf der Verwendung einer Region des viralen Genoms, die zwischen den verschiedenen Spezies einige Unterschiede aufweist (Claas et al. 2005). Innerhalb der einzelnen Spezies ist das Genom stärker konserviert. Die verwendeten PCR-Primer sind daher zu keiner viralen Sequenz hundertprozentig komplementär, die vorhandenen Fehlpaarungen sind jedoch so verteilt, dass für alle Serotypen ähnliche Schmelztemperaturen erzielt werden (Heim et al. 2003). Im Falle einer isothermalen Nachweisreaktion ist dieses Vorgehen ungeeignet, da die gesamte Reaktion bei $42{ }^{\circ} \mathrm{C}$ durchgeführt wird. Für diese Arbeit wurde der Fokus daher

auf die Spezies B, C und E gelegt, die besonders als Erreger von Atemwegsinfektionen bekannt sind, und für jede Spezies ein Primerpaar und eine Fluoreszenzsonde entworfen. Das Vorgehen orientierte sich dabei an der Arbeit von Claas et al. (Claas et al. 2005). Ausgehend von einem Alignmet mehrerer zufällig gewähler GenBank-Sequenzen wurden zunächst 14 Primerkandidaten und ein Fluoreszenzsonde für den Nachweis von HAdV Spezies B entworfen und anhand einer synthetischen Standardpräparation von HAdV-7DNS untersucht. Die Oligonukleotide und die Sonde wurden in einem weiteren Schritt für den Nachweis der Spezies C und E in den entsprechenden Positionen modifiziert (vergl. Abb. 6.3, Anhang).

\subsubsection{Herstellung synthetischer Adenovirus-Standard-DNS}

Zur Entwicklung der RPA-Nachweisreaktion für humane Adenoviren wurden drei quantitative synthetische Nukleinsäurestandards hergestellt. Es wurden die Serotypen 
HAdV-7 (Spezies B), HAdV-1 (Spezies C) und HAdV-4 (Spezies E) als Vertreter ihrer jeweiligen Spezies ausgewählt. Die virale DNS wurde aus Zellkulturüberständen extrahiert (Kapitel 2.2.1.1). Eine 140 bp lange Sequenz des Hexon-Gens wurde mittels PCR unter Verwendung spezifischer Primer amplifiziert (Primer: HAdV-1C for, HAdV1C rev; HAdV-4E for, HAdV-4E rev; HAdV-7B for, HAdV-7B rev).

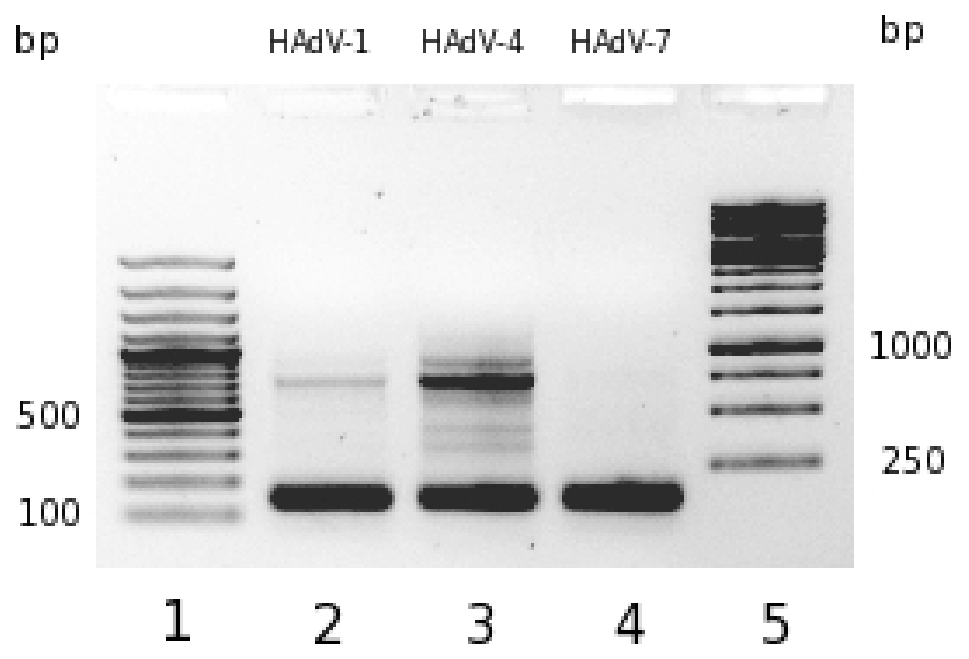

Abb. 3.14: Spezifische HAdV-PCR-Gelelektrophorese.

Es wurden pro Spur jeweils 2,5 $\mu$ l DNS-Längenstandard bzw. $5 \mu$ l PCR-Produkt eingesetzt. Spur 1 enthält einen 100 bp-Längenstandard, Spur 5 enthält einen 1 kB-Längenstandard. Spur 2 enthält den PCR-Ansatz aus HAdV-1 (C), Spur 3 enthält einen PCR-Ansatz aus HAdV-4 (E) und Spur 4 enthält einen PCR-Ansatz aus HAdV-7 (B) Zellkulturüberständen. Alle drei Spuren zeigen die erwartete Bande bei ca. 140 bp. Aufgrund der enthaltenen Verunreinigungen wurden die erwünschten Fragmente durch eine Gelextraktion aufgereinigt.

Die erwünschten Sequenzen wurden mittels präparativer Agarosegelelektrophorese (Kapitel 2.2.1.5) aufgereinigt. Zur dauerhaften Sicherung der Sequenzen wurde, analog zum Vorgehen bei der Produktion des Influenza-A-Standards (Kapitel 3.1.1.2), eine TAKlonierung in pCRII ${ }^{\circledR}$-Vektor durchgeführt. Die DNS wurde mit linearer Vektor-DNS ligiert (Kapitel 2.2.1.6), chemisch kompetente E.coli-Bakterien wurden transformiert (Kapitel 2.2.1.8) und mehrere Einzelklone in monoklonale Flüssigkulturen überführt (Kapitel 2.2.1.9). Der Erfolg der Transformation wurde durch DNS-Minipräparation (Kapitel 2.2.1.11) und anschließenden Restriktionsverdau mit der Nuklease EcoRI überprüft (Kapitel 2.2.1.12). 


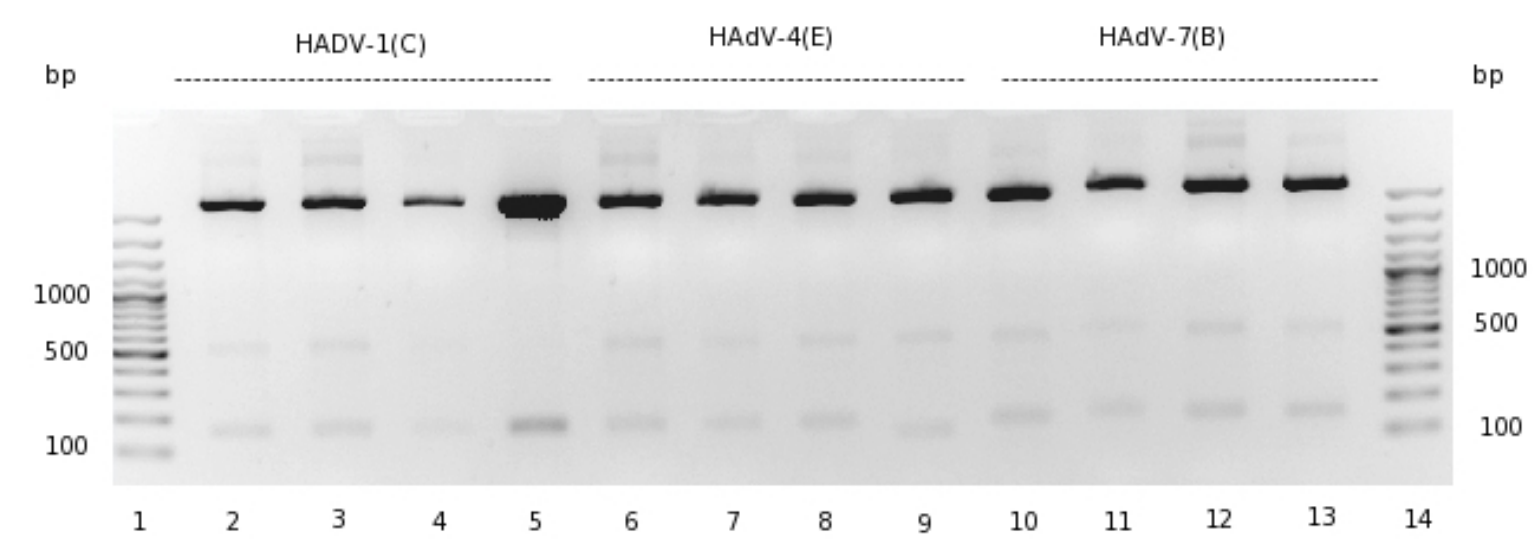

Abb. 3.15: DNS-Minipräparation verschiedener HAdV-Klone.

Es wurden pro Spur jeweils 2,5 $\mu$ l DNS-Längenstandard bzw. $5 \mu$ l EcoRI restriktionsverdaute Plasmid-DNS eingesetzt. Spur 1 und 14 enthalten einen 100 bp-Längenstandard.

Alle überprüften Bakterienklone zeigten die erwartete Bande in Größe von ca. 140 bp. Für jede Spezies wurde ein erfolgreich transformierter Bakterienklon ausgewählt und die durch DNS-Minipräparation gewonnene Plasmid-DNS sequenziert (Primer M13 Rev, Kapitel 2.2.1.14). Eine BLAST-Analyse der gewonnenen Sequenzen ergab für das HAdV-1(C)-Insert eine hundertprozentige Übereinstimmung mit Sequenzen der Serotypen 2, 5 und 7, für das HAdV-4(E)-Insert eine hundertprozentige Übereinstimmung mit Sequenzen der Serotypen 4, 26 und 39 sowie der Spezies E und für das HAdV-7(B)Insert eine hundertprozentige Übereinstimmung mit Sequenzen der Serotypen 3, 5, 7, 16, 21 und 50. Zur Gewinnung größerer Mengen Plasmid-DNS wurden erneut monoklonale Flüssigkulturen angelegt und eine DNS-Midipräparation durchgeführt (Kapitel 2.2.1.12). Zum Auflösen der Supercoiled-Struktur der zirkulären Plasmid-DNS wurde diese mittels Restriktionsverdau linearisiert (Kapitel 2.2.1.13). Dazu wurde die Plasmid-DNS mit der Nuklease XnmI verdaut. Die Klonierungskonstrukte weisen für dieses Enzym eine einzige Schnittstelle in ca. 2 kb Entfernung zur multiplen Klonierungsstelle auf. Dieses Vorgehen war notwendig, da ringförmige DNS einige ungünstige Eigenschaften aufweist. Liegen beide Stränge des Moleküls als kovalent geschlossene Ringe vor, nimmt es eine sogenannte Supercoiled-Struktur ein. Derartige geschlossene, zirkuläre DNS-Moleküle lassen sich schlecht mit Ethidiumbromid anfärben und ihr Laufverhalten in der Agarosegelelektrophorese lässt sich nicht vorhersagen (Sambrook und Russell 2001). Mehrere Plasmide dieser Form können sich zudem zu kettenartigen Gebilden verknoten, was das Anlegen einer exakt quantifizierten Verdünnungsreihe erschwert (Vologodski 
1992). Durch die enzymatische Spaltung der kovalenten Bindung eines Stranges der doppelsträngigen DNS kann das Plasmid in eine sogenannte „entspannte“ Ringform überführt werden. Am einfachsten weiterzuverarbeiten ist jedoch die durch Restriktionsendonukleasen linearisierte DNS. Lineare DNS weist ein vorhersagbares Verhalten in der Agarosegelelektrophorese auf und verteilt sich gleichmäßig im zur Verdünnung verwendeten Puffer. Des Weiteren ähnelt die Tertiärstruktur dieser linearen synthetischen Moleküle eher der Tertiärstruktur der linearen viralen DNS. Die genau quantifizierten Verdünnungsreihen dieser Moleküle wurden als Standard für die weiteren Untersuchungen verwendet.

Die durch den Restriktionsverdau gewonnenen linearen DNS-Fragmente von ca. 4,1 kb Länge wurden durch präparative Agarosegelelektrophorese aufgereinigt (Kapitel 2.2.1.5).

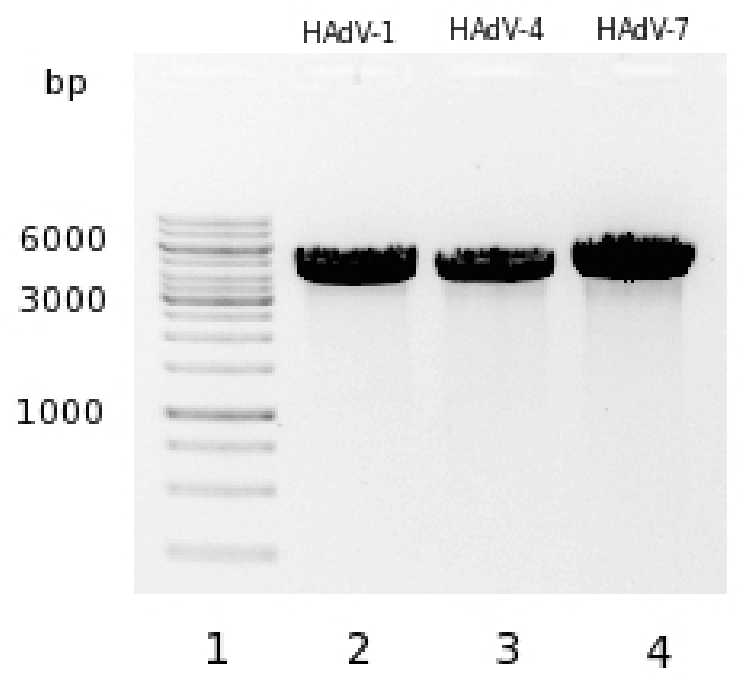

Abb. 3.16: Gelelektrophorese der zur Linearisierung XmnI restriktionsverdauten Plasmid-DNS. Es wurden pro Spur jeweils 2,5 $\mu$ l DNS-Längenstandard bzw. $5 \mu$ l Plasmid-DNS eingesetzt. Spur 1 enthält einen 1 kb-Längenstandard. Spur 2 enthält die restriktionsverdaute HAdV-1(C)Plasmid-DNS. Spur 3 enthält den HAdV-4(E)- und Spur 4 den HAdV-7(B)-Standard. Alle drei Spuren zeigen die erwartete Bande bei ca. 4,1 kb. Unverdaute zirkuläre Klonierungskonstrukte würden aufgrund ihrer Supercoiled-Struktur ein anderes Laufverhalten in der Elektrophorese zeigen. Diese sind jedoch nicht sichtbar.

Zur genauen Quantifizierung der Standard-DNS wurde eine photometrische Messung mit dem Fluoreszenzfarbstoff PicoGreen ${ }^{\circledR}$ durchgeführt (Kapitel 2.2.2.2). Für den HAdV-1Standard ergab dies eine DNS-Konzentration von 171,3 ng/ $\mu$ l. Der HAdV-4-Standard wies eine DNS-Konzentration von 112,6 ng/ $\mu \mathrm{l}$ auf. Der HAdV-7-Standard zeigte eine 
DNS-Konzentration von 83,6 ng/ $\mu$ l. Für alle drei Serotypen wurde, ausgehend von einer Größe des Klonierungskonstruktes von 4086 bp und einem Molekulargewicht von $2696760 \mathrm{~g} / \mathrm{mol}$, eine entsprechende Verdünnungsreihe mit $10^{1}$ bis $10^{7}$ Molekülen $/ \mu \mathrm{l}$ in TE-Puffer angelegt. Die Qualität der Standardreihen wurde durch Echtzeit-PCR überprüft (Primer: HAdV-1C for, HAdV-1C rev; HAdV-4E for, HAdV-4E rev; HAdV-7B for, HAdV-7B rev; Sonde: HAdV Probe; Kapitel 2.2.2.5).
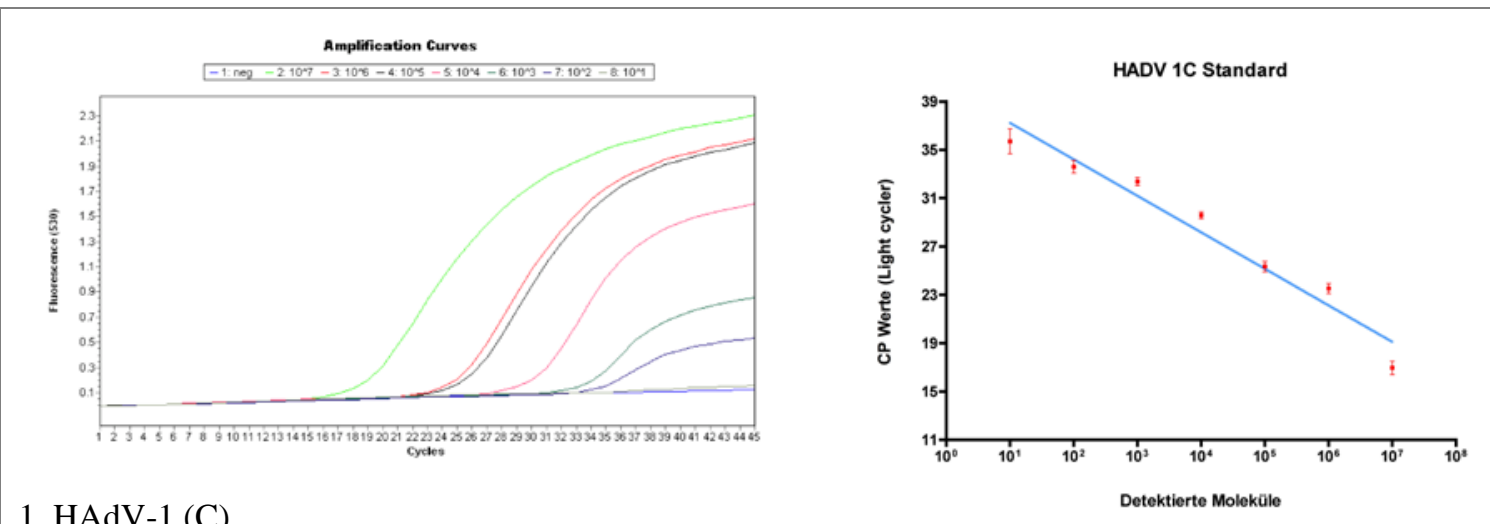

1. HAdV-1 (C)
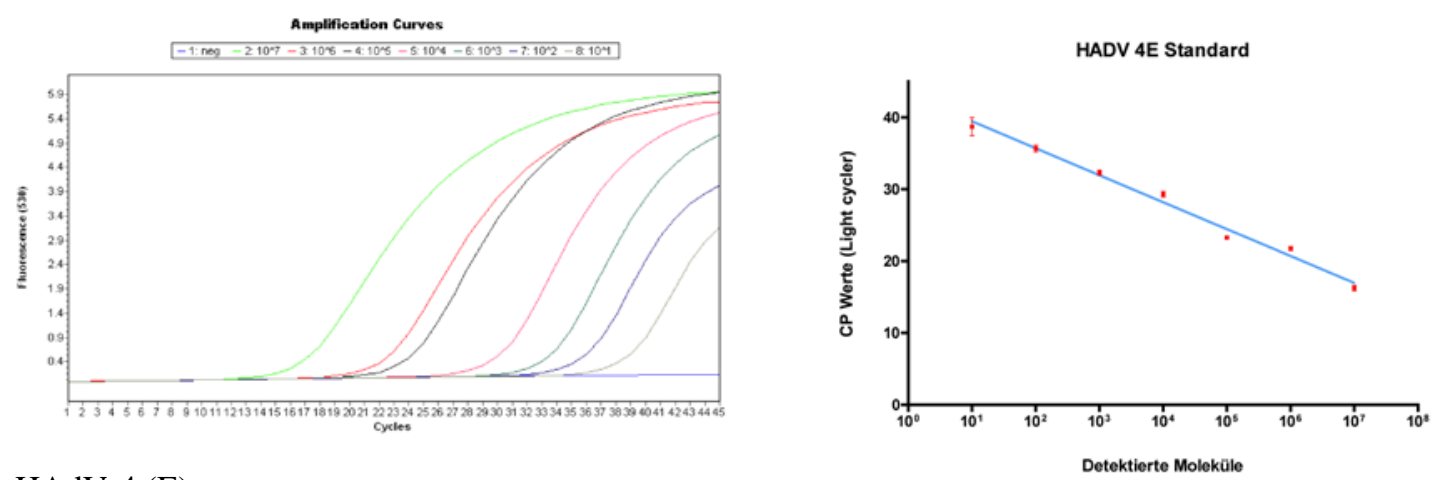

2. HAdV-4 (E)
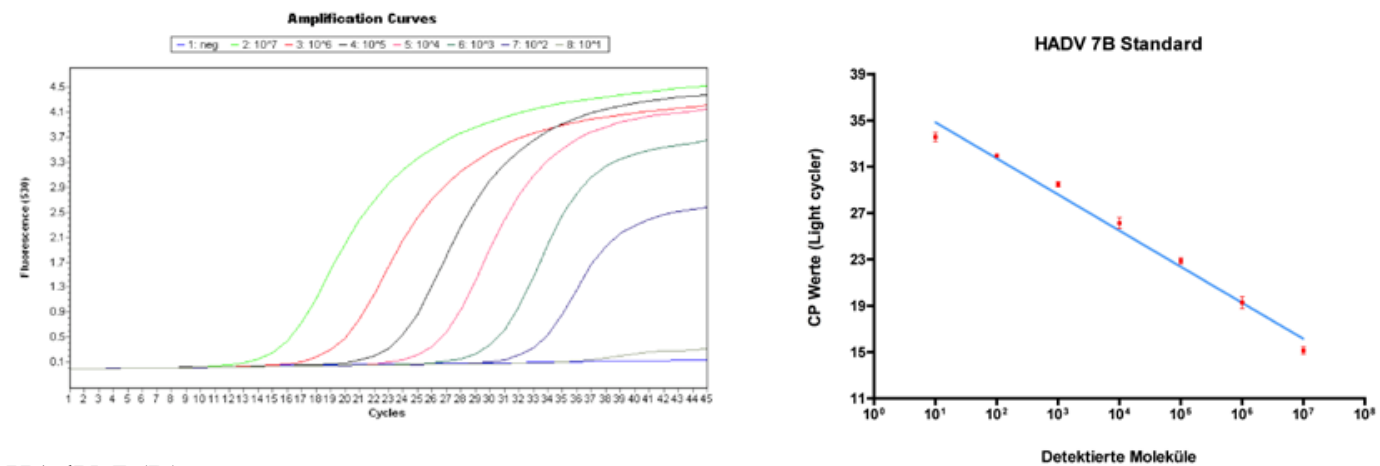

3. HAdV-7 (B)

Abb. 3.17: $\quad$ Echtzeit-PCR-Messung der Standardverdünnungen von HAdV 1(C), 4(E) und 7(B). Links ist beispielhaft eine Echtzeit-PCR-Messung der jeweiligen Standardreihe gezeigt. Die rechte Grafik zeigt die korrespondierenden, auf Grundlage von jeweils drei Messungen erstellten Standardgeraden. 


\subsubsection{Evaluation der HAdV-RPA-Primerkandidaten}

Zur Evaluation der HAdV-RPA-Primer wurden zunächst 14 Primerkandidaten und eine exo-Sonde für den Serotyp 7 entworfen und mit jeweils $10^{5}$ Molekülen der entsprechenden Standard-DNS evaluiert. Die effektivste Kombination (HAdV-7B UP, HAdV-7B DP und HAdV-7B exo Probe) wurde entsprechend dem Alignment an den zwischen den verschiedenen Spezies unterschiedlichen Positionen modifiziert. Die darauffolgenden Reaktionen wurden als multiplex Reaktionen durchgeführt. Als Vorwärtsprimer wurde ein äquimolares Gemisch aus HAdV-1C UP, HAdV-4E UP und HAdV-7B UP eingesetzt. Als Rückwärtsprimer diente ein äquimolares Gemisch aus HAdV-1C DP, HAdV-4E DP und HAdV-7B DP. Als Sonde wurde ein äquimolares Gemisch aus HAdV-1C exo Probe, HAdV-4E exo Probe und HAdV-7B exo Probe eingesetzt.

\subsubsection{Analytische Sensitivität der Adenovirus-RPA}

Um die analytische Sensitivität des Adenovirus-Nachweises zu untersuchen, wurden die drei synthetischen DNS-Standardreihen in den Verdünnungsstufen 10 bis $10^{7}$ in die Multiplex-RPA-Reaktion eingesetzt. Für jeden der drei untersuchten Serotypen wurden acht gleichartige Läufe durchgeführt. Die Ergebnisse wurden statistisch durch eine Probitanalyse ausgewertet. In einem $50 \mu$ l-Reaktionsansatz betrug die 95\%Nachweisgrenze der Adenovirus-Multiplexreaktion für HAdV-1(C) 12 Moleküle, für HAdV-4(E) 131 Moleküle und für HAdV-7(B) 16 Moleküle. Die Reaktionsdauer betrug für alle Reaktionen stets weniger als 15 Minuten (vergl. Tabelle 3.3).

Tabelle 3.3 Sensitivität der HAdV-RPA- und Echtzeit-PCR-Assays im Vergleich.

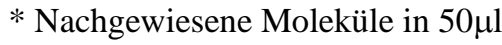

\begin{tabular}{|lccccc|}
\hline Erreger und Zielgen & $\begin{array}{c}\text { Sensitivität* } \\
\text { Echtzeit-PCR }\end{array}$ & $\begin{array}{c}\text { Sensitivität* } \\
\text { RPA }\end{array}$ & $\begin{array}{c}\text { Probit Sensitivität* } \\
\text { (95\%) RPA }\end{array}$ & $\begin{array}{c}\text { Laufzeit } \\
\text { (min) }\end{array}$ \\
\hline $\begin{array}{l}\text { Humanes } \\
\text { (Hexon) }\end{array}$ & Adenovirus-1 & $10^{1}-10^{2}$ & $10^{1}-10^{2}$ & 8 Läufe & 12 \\
\hline $\begin{array}{l}\text { Humanes } \\
\text { (Hexon) }\end{array}$ & Adenovirus-4 & $10^{1-10^{2}}$ & $10^{2}-10^{3}$ & 131 & 13 \\
\hline $\begin{array}{l}\text { Humanes } \\
\text { (Hexon) }\end{array}$ & Adenovirus-7 & $10^{1}$ & $10^{1}-10^{2}$ & 16 & 14 \\
\hline
\end{tabular}




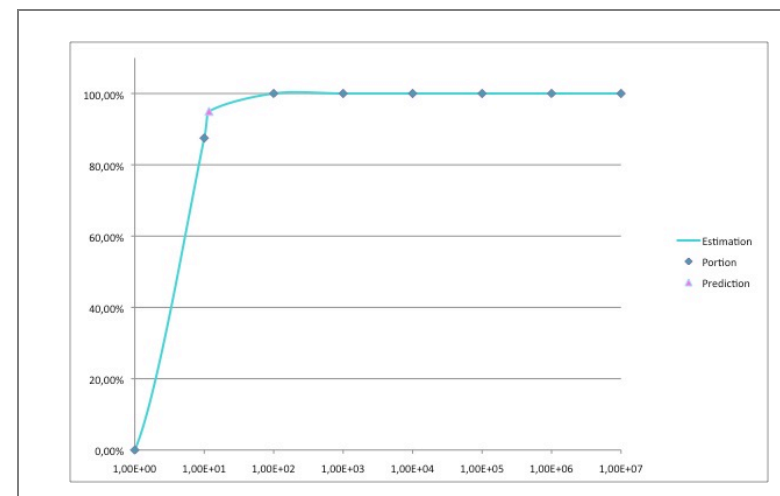

1. HAdV-1 (C)
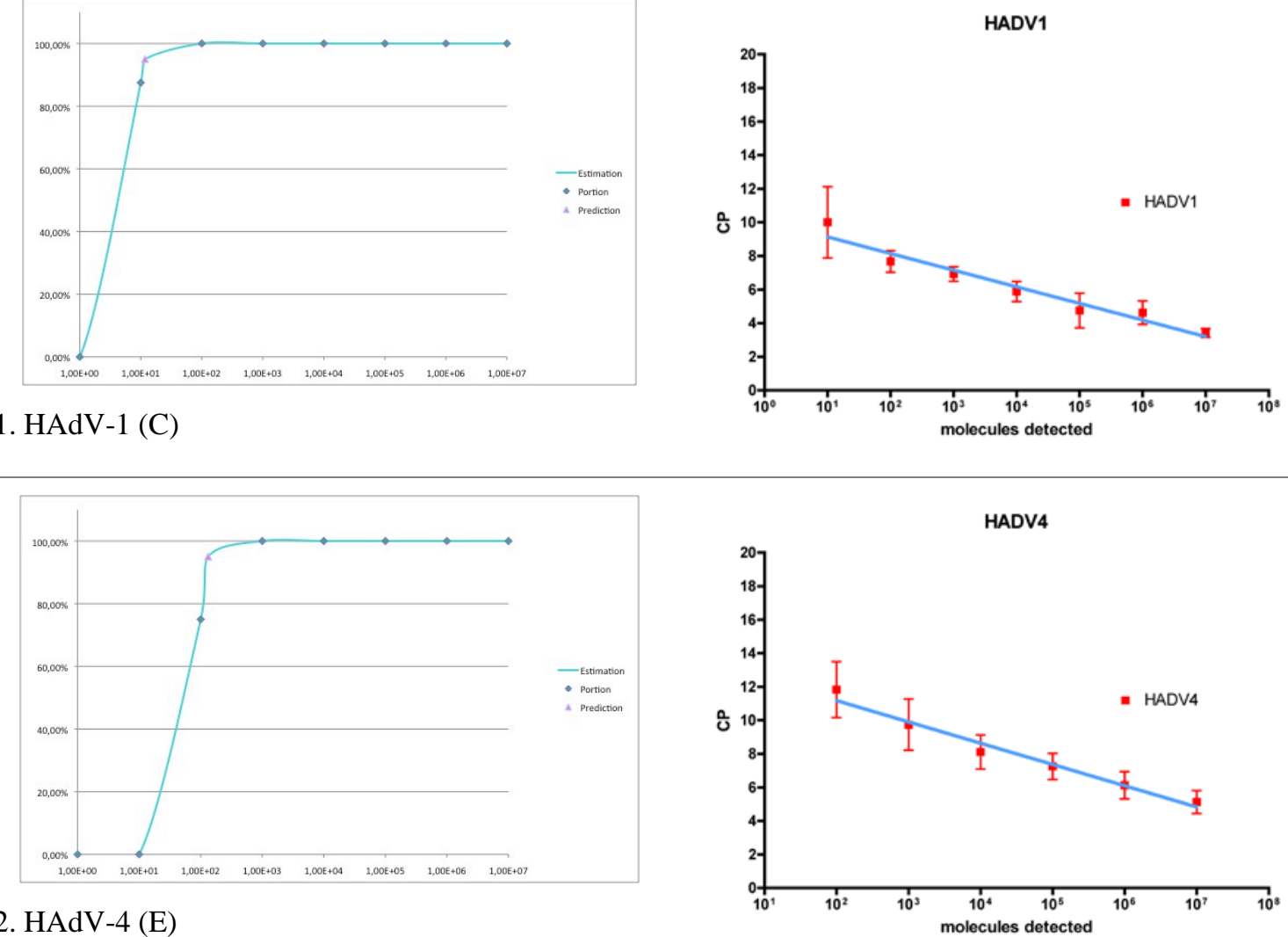

2. HAdV-4 (E)

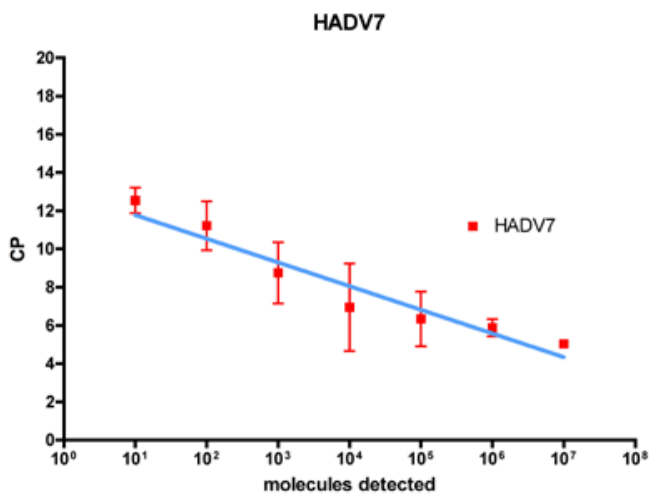

3. HAdV-7 (B)

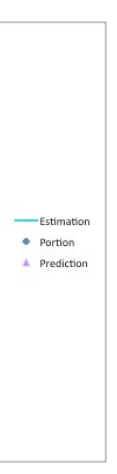

Abb. 3.18:

Standardkurven der Reaktionsgeschwindigkeit und 95\%-Sensitivität der HAdV-multiplex-RPA zum Nachweis synthetischer DNS der Serotypen 1(C), 4(E) und 7(B).

Links ist die Probit-Analyse der 95\%-Sensitivität der einzelnen Reaktionen gezeigt. Die rechte Spalte zeigt Regressionsgeraden der Reaktionsgeschwindigkeit in Minuten, berechnet aus den Ergebnissen von je 8 RT-RPA-Durchläufen mit den quantitativen molekularen Standards. Auf Grundlage dieser Messungen werden theoretisch in 95\% der Testläufe 12 Moleküle HAdV-1-DNS im Reaktionsansatz in weniger als 14 Minuten nachgewiesen. Der Nachweis von HAdV-4 benötigt bei einer Sensitivität von 131 Molekülen weniger als 15 Minuten. HAdV-7 wird mit einer Sensitivität von 16 Molekülen in weniger als 15 Minuten nachgewiesen. 


\subsubsection{Analytische Spezifität der Adenovirus-RPA}

Zur Beurteilung der analytischen Spezifität bzw. eventueller Kreuzreaktivität wurde genomische RNS von Influenza-A-Virus und Influenza-B-Virus in die Adenovirus Reaktion eingesetzt. Dabei konnte keine Kreuzreaktivität nachgewiesen werden. 


\section{Diskussion}

Akute Atemwegserkrankungen, von der einfachen Erkältung bis zur lebensbedrohlichen Influenza, sind in Deutschland besonders häufige Gründe für Arztkontakte. Der Kliniker muss dabei, oft mit begrenzten diagnostischen Mitteln, schnell eine Diagnose stellen und die richtige Therapie einleiten. Im Falle der Influenza kann durch eine frühzeitige Diagnosesicherung eine spezifische antivirale Therapie eingeleitet werden und dadurch sowohl der Antibiotikaverbrauch als auch der Verlauf der Erkrankungen positiv beeinflusst werden (Falsey et al. 2007). Es konnte gezeigt werden, dass die labortechnische Diagnosesicherung in der überwiegenden Mehrzahl der Fälle viraler Atemwegsinfektionen bereits 12 Stunden nach dem ersten Arztkontakt jeglichen nachweisbaren Einfluss auf den Verlauf der Erkrankung verliert (Wishaupt et al. 2011). Eine Sofortdiagnostik am Krankenbett, bzw. in der Arztpraxis (Point-of-Care) scheint also insbesondere im Hinblick auf die Influenza erstrebenswert. Die derzeit eingesetzten Schnellteste (PoC-Tests) weisen virale Proteine durch enzym-gekoppelte Immunassays nach. Sie zeigen jedoch unbefriedigende Resultate, besonders bezüglich ihrer Sensitivität, die in einigen Studien mit nur 60\% angegeben wird (Walsh et al. 2002). Die PCR erfordert einen größeren zeitlichen und apparativen Aufwand, weshalb die Ergebnisse dem behandelnden Arzt nicht zeitnah zur Verfügung stehen. Ziel dieser Arbeit war die Entwicklung eines, bezüglich der Sensitivität mit der PCR vergleichbaren, PoCSchnelltests zum Nachweis viraler Erreger von Atemwegserkrankungen, der schnell durchzuführen ist und einen minimalen apparativen Aufwand erfordert. Dazu wurde der nukleinsäurebasierte isothermale Nachweis durch Rekombinase-PolymeraseAmplifikation (RPA) gewählt, da dieser mit geringem apparativen Aufwand in 20 Minuten am Patientenbett oder in der Arztpraxis durchgeführt werden kann.

Es wurden Nachweisreaktionen für Influenza-A-Virus, Influenza-B-Virus und differentialdiagnostisch relevante humane Adenoviren entwickelt. Influenza-A- und -BViren sind behüllte ssRNS-Viren aus der Familie der Orthomyxoviridae, deren Genom in Negativstrangorientierung vorliegt. Humane Adenoviren sind unbehüllte dsDNS-Viren aus der Familie der Adenoviridae. Da die RPA lediglich zur Amplifikation von DNS geeignet ist, musste sie für den Nachweis der Influenzaviren durch den Zusatz von 
reverser Transkriptase zur RT-RPA erweitert werden. Die RPA-Primer dienen dabei zusätzlich als spezifische Primer für die reverse Transkription.

\subsection{Entwurf der RPA-Amplikons}

Zum spezifischen nukleinsäurebasierten Nachweis von Krankheitserregern einer bestimmten Spezies ist es notwendig, eine sogenannte konservierte Region des Genoms als Ziel für die Nachweisreaktion zu identifizieren (Gardner et al. 2003). Wie alle Lebewesen sind auch Viren einem Selektionsdruck unterworfen, der zu einer ständigen Veränderung ihres Genoms durch die Mechanismen der Mutation und Selektion führt. Lediglich einige Genomanteile sind für die Funktion des Virus, und damit sein evolutionäres Fortbestehen derart wichtig, dass sie sich in diesem Prozess kaum verändern und so potentielle Ziele für einen nukleinsäurebasierten Nachweis darstellen. Diese Zielregionen müssen zwei wesentliche Bedingungen erfüllen: Sie sollten einerseits in allen Exemplaren der nachzuweisenden Spezies vorkommen und andererseits spezifisch für diese Spezies sein, um falsch positive Ergebnisse zu vermeiden.

Eine Computeranalyse von in Datenbanken abgelegten bekannten Sequenzen kann dazu einen wertvollen Beitrag leisten (Chou et al. 2006). Da die bei der RPA eingesetzten Oligonukleotide mit 30-35 nt relativ lang sind, mussten zunächst entsprechende konservierte Regionen gefunden werden. Dies wurde für die einzelnen Erreger, orientiert an zuvor veröffentlichten Echtzeit-PCR-Reaktionen, durch einen linearen Sequenzvergleich von zufällig gewählten GenBank-Sequenzen der interessanten Gene untersucht.

So orientierte sich der lineare Sequenzvergleich des Matrixprotein-Gens des Influenza-AVirus am PCR-Amplikon von Spackman et al. (Spackman et al. 2002). Zum Nachweis von Influenza-B-Virus wurde eine konservierte Region des Hämagglutinin-Gens gewählt. Der lineare Sequenzvergleich des Hexon-Gens der humanen Adenoviren orientierte sich an einem PCR-Amplikon von Claas et al. (Claas et al. 2005). Beim Entwurf dieses Amplikons zum allgemeinen Nachweis differentialdiagnostisch relevanter humaner Adenoviren stellte die hohe Variabilität zwischen den 57 verschiedenen Serotypen ein besonderes Problem dar. Die aus der Literatur zu entnehmenden PCR-Reaktionen basieren in der Regel auf für die RPA zu kurzen Oligonukleotiden, die für keinen Serotyp 
genau passen (Heim et al. 2003). Die vorhandenen Fehlpaarungen sind dabei jedoch so verteilt, dass für alle Serotypen ähnliche Schmelztemperaturen erzielt werden. Da die RPA bei konstanten $42^{\circ} \mathrm{C}$ durchgeführt wird, war dies keine Option. Schwerwiegende Atemwegsinfektionen werden jedoch nur von drei der sieben Spezies der humanen Adenoviren (B, C und E) verursacht (Fields et al. 2007). So konnte sich die Nachweisreaktion auf diese konzentrieren. Innerhalb der verschiedenen Spezies sind die untersuchten Regionen so stark konserviert, dass durch den Entwurf je eines Primerpaares und einer Sonde für jede Spezies in einem Multiplexansatz alle drei für Atemwegserkrankungen relevanten Spezies nachgewiesen werden können.

Die durch derartige lineare Sequenzvergleiche gewonnenen Kandidatenregionen für das RPA-Amplikon müssen jedoch, anders als bei PCR-Reaktionen, erst weiter bezüglich ihrer Effektivität evaluiert werden, ehe das endgültige Amplikon gefunden ist. Ein reines in silico Design des Amplikons ist also nicht möglich.

Anders als die etablierte Technik der Echtzeit-PCR wird die Funktionsweise der RPA, und insbesondere des Stranginvasionsprozesses, noch nicht vollständig verstanden. Deshalb können keine genauen Prognosen über die Funktionalität eines gegebenen Primerpaares gemacht werden. Es ist vielmehr notwendig, in einem aufwendigen Versuch-und-Irrtum-Prozess möglichst viele Primerkanditaten zu untersuchen, um eine optimale Kombination zu finden. Die Herstellerfirma der RPA-Reagenzien empfiehlt dabei ein Vorgehen in drei Schritten. Als Erstes sollte die Zielregion durch relativ weit von einander entfernte Oligonukleotide grob eingegrenzt werden. In einem zweiten Schritt sollte, ausgehend vom besten Ergebnis des ersten Schrittes, das optimale Ziel in der direkten Umgebung weiter präzisiert werden. In einem letzten Schritt sollte die Länge der optimalen Oligonukleotide aus Schritt zwei im Rahmen von 30 -35 nt variiert werden, um so die endgültige optimale Primerpaarung festzulegen. Dabei wird empfohlen, jeweils einen Vorwärtsprimer 7 Mal mit verschiedenen Rückwärtsprimern einzusetzen und den Rückwärtsprimer, der in diesem Versuch das beste Ergebnis erzielt, in einem weiteren Schritt mit verschiedenen Vorwärtsprimern zu evaluieren (Quelle: TwistDX RPA Handbuch).

Aufgrund der hohen Variabilität der viralen Genome war es nicht immer möglich, diesen Herstellerempfehlungen konsequent zu folgen. Es wurden jedoch anhand der linearen Sequenzvergleiche (siehe Kapitel 6.1), im Rahmen der vorhandenen konservierten 
Regionen, für jedes Virus mindestens 14 Primerkandidaten entworfen und daraus die bestmögliche Kombination bestimmt.

Möglicherweise wäre durch eine noch konsequentere Evaluation einer größeren Menge von Primerkandidaten eine weitere Verbesserung der Sensitivität der Reaktionen möglich, dies würde jedoch ein Verlassen der konservierten Regionen des viralen Genoms bedeuten und die resultierenden Reaktionen wären für den allgemeinen Nachweis einer viralen Spezies ungeeignet. Beim Entwurf von Oligonukleotiden und Sonden für Echtzeit-PCR basierte Nachweisverfahren ist besonders deren Bindungsstärke bzw. Schmelztemperatur $T_{M}$ zu beachten. Diese ist definiert als die Temperatur, bei welcher 50\% des Oligonukleotides und seines passenden Komplementärstranges als Doppelhelix vorliegen. Eine Berechnung dieser Schmelztemperatur ist nur annähernd möglich, da dazu viele verschiedene Faktoren berücksichtig werden müssen. Zunächst ist es naheliegend, den $\mathrm{G}+\mathrm{C}$ Gehalt sowie die Länge des Oligonukleotides in die Berechnung mit einzubeziehen, da die Paarung A-T zwei und die Paarung C-G drei Wasserstoffbrückenbindungen ausbilden. Die Wasserstoffbrückenbindungen sind für einen Großteil der Bindungsstärke verantwortlich. Dies wird in der einfachsten Gleichung zur Schmelztemperaturberechnung, der sogenannten Wallace Regel, berücksichtigt, wobei jedes A oder $\mathrm{T} 2^{\circ} \mathrm{C}$ und jedes $\mathrm{G}$ oder $\mathrm{C} 4^{\circ} \mathrm{C}$ zur Schmelztemperatur beiträgt (Wallace et al. 1979). Diese Faustformel berücksichtigt jedoch einige an der Bindung beteiligte Kräfte nicht und gilt nur bei einer NaCl-Konzentration von 0,9 M und einer Oligonukleotidlänge von 14-20 nt. Zur genaueren Berechnung müssen Phänomene wie $\pi$ $\pi$-Wechselwirkungen, elektrostatische Kräfte und konformative Entropie berücksichtigt werden (SantaLucia 1998). Diese werden durch ein Vorgehen nach der „Nearest Neighbor Methode“ stärker mit einbezogen. Dabei wird für jede mögliche Kombination von Dinukleotiden empirisch die Bindungsstärke bestimmt. Die Sequenz des untersuchten Oligonukleotids wird dann in eine Abfolge von Dinukleotiden zerlegt und ihr jeweiliger Beitrag zur gesamten Bindungsenergie einzeln berücksichtigt. Diese Berechnungsweise ermöglicht eine genauere Vorhersage der $T_{M}$ und auch die zur Zeit genauesten Voraussagen der Sekundärstrukturbildung von Nukleinsäuren.

$\mathrm{Zu}$ diesem Zweck wurde für diese Arbeit mit der Software VisualOmp eine Sekundästrukturberechnung in silico simuliert, um Primer Dimere oder Primer Sonden Hybride vorherzusagen bzw. a priori auszuschließen. 
Beim Entwurf der RPA-Amplikons können diese Hilfsmittel nur einen kleinen Beitrag leisten, da der Prozess der Stranginvasion durch die Rekombinase derzeit nicht umfassend verstanden wird. So bleibt das empirische Erproben einer größeren Menge verschiedener Oligonukleotide die einzige Möglichkeit die Reaktion zu optimieren. Eine typische Konstellation von Primern, die besonders gute Ergebnisse lieferte, wurde hierbei nicht ersichtlich.

\subsection{Sensitivitätsvergleich: RPA, Echtzeit-PCR und Alternativen}

Um die genaue Sensitivität der einzelnen Reaktionen bestimmen zu können und diese mit dem Goldstandard Echtzeit-PCR zu vergleichen, wurden Standard-Verdünnungsreihen mit exakt quantifizierten Mengen synthetischer viraler DNS bzw. RNS hergestellt.

Die Quantitäten dieser Verdünnungsreihen wurden mittels Echtzeit-PCR überprüft. Die RPA-Reaktion kann, in ihrer derzeitigen Form, keine Aussagen über die Quantität der nachgewiesenen Zielsequenzen treffen, da weder die Reaktionsgeschwindigkeit noch die Signalstärke mit ihr korrelieren.

Für das Influenza-A-Virus wurde Standard-RNS vom M-Gen (Segment 7) abgeleitet (Kapitel 2.2.1.15).

Für den Influenza-B-Standard wurde eine bereits vorhandene, 170 bp lange, in pCR ${ }^{\circledR} \mathrm{II}-$ Plasmid gesichterte cDNS-Sequenz aus dem Hämagglutinin-Gen des viralen Segmentes 4 verwendet (Influenza B/Florida/02/2008, GenBank Nr. FJ152012).

Zur Beurteilung der Sensitivität der HAdV-Nachweisreaktion wurden drei quantitative Standardverdünnungsreihen von synthetischer DNS eines 137 bp langen Fragmentes aus dem Hexon-Gen hergestellt. Dabei diente HAdV-1 als Vertreter der Spezies C, HAdV-4 als Vertreter der Spezies E und HAdV-7 als Vertreter der Spezies B. Die Sequenzierung und BLAST-Analyse der Fragmente ergab für das HAdV-1(C)-Insert eine hundertprozentige Übereinstimmung mit Sequenzen der Serotypen 2(C), 5(C) und 7(B), für das HAdV-4(E)-Insert eine hundertprozentige Übereinstimmung mit Sequenzen der Spezies E sowie der Serotypen 4 (E), 26(D) und 39(D) und für das HAdV-7(B)-Insert eine hundertprozentige Übereinstimmung mit Sequenzen der Serotypen 3(B), 5(C), 7(B), 16(B), 21(B) und 50(B).

Die synthetischen, quantitativen Standardverdünnungsreihen der fünf untersuchten Viren wurden zunächst mit Echtzeit-PCR bzw. Echtzeit-RT-PCR überprüft. Für jedes Virus 
wurden in dreifacher Ausführung alle 7 Verdünnungsstufen von 10 bis $10^{7}$ Molekülen pro $\mu \mathrm{l}$ in die Reaktion eingesetzt. Alle Verdünnungsreihen zeigten die erwartete zeitliche Abfolge der CP-Werte der Fluoreszenzsignale und eine Nachweisgrenze zwischen 10 und $10^{2}$ Molekülen. Das entsprach weitgehend den in der Literatur angegebenen Werten, so dass die PCR-Reaktionen gut für die Kalibrierung der Standardverdünnungsreihen verwendbar waren. So geben Claas et al. die Sensitivität ihrer HAdV-Reaktion mit 12,5 Molekülen/ $50 \mu \mathrm{l}$ an (Claas et al. 2005). Der RT-PCR Nachweis von Influenza-A- und B-Virus gelingt laut aktuellen Veröffentlichungen mit einer Nachweisgrenze von ca. 125 Molekülen/ 50 $\mu \mathrm{l}$ (Boivin et al. 2004). Die derart per PCR kalibrierten Standardverdünnungsreihen wurden zur Überprüfung der Sensitivität in die RPAReaktion eingesetzt.

Die RPA-Reaktionen wurden bei konstanten $42^{\circ} \mathrm{C}$ für 20 Minuten in einem ESEQuant Tubescanner durchgeführt. Die Multiplexreaktion zum Nachweis humaner Adenoviren überschritt den Schwellenwert in allen positiven Testläufen in weniger als 15 Minuten.

Der Nachweis der Influenzaviren benötigte nie länger als acht Minuten. Dabei lag die Nachweisgrenze im Bereich zwischen 10 und $10^{3}$ Molekülen pro $50 \mu$ l-Reaktionsansatz. Die Statistische Analyse mit dem Probit-Modell ergab eine 95\%-Nachweisgrenze der Influenza-A-Reaktion von 218 Molekülen. Die Influenza-B-Nachweisgrenze betrug 131 Moleküle. Der HAdV-1-Nachweis benötigte 12, HAdV-4 131 und HAdV-7 16 Moleküle. Bei diesen Werten handelt es sich um statistische Schätzwerte der theoretischen Molekülanzahl, bei welcher, auf Grundlage der durchgeführten Messungen, 95\% der Testläufe ein positives Ergebnis zeigen. Auch wenn sie keinen Anspruch auf absolute Gültigkeit erheben können, zeigen sie doch sehr gut, dass die Sensitivität der RPAReaktionen mit der Sensitivität der Echtzeit-PCR vergleichbar ist (Tabelle 5.1). Dabei fällt auf, dass der Nachweis von DNS etwas sensitiver gelingt als der Nachweis von RNS. Dies ist wahrscheinlich auf Sekundärstrukturen der einzelsträngigen RNS zurückzuführen, welche das Anlagern der Primer zur reversen Transkription behindern können (Kuo et al. 1997). Auch die scheinbar etwas geringere Sensitivität des InfluenzaA-Nachweises gegenüber dem Influenza-B-Nachweis könnte durch eine verstärkte Ausbildung von Sekundärstrukturen innerhalb der synthetischen Standard-RNS erklärt werden, da das verwendete Influenza-A-Molekül deutlich länger ist als das Influenza-B- 
RNS-Fragment. Die gemessene Sensitivität des Influenza-A-Nachweises entspricht also genauer der Sensitivität des Nachweises natürlich vorkommender Nukleinsäuren, während die scheinbar höhere Sensitivität des Influenza-B-Nachweises nur für das kurze synthetische Standard-Molekül gilt. Der Nachweis natürlich vorkommender Influenza-BRNS sollte aufgrund von Sekundärstrukturen theoretisch etwas weniger sensitiv gelingen als hier gemessen.

Derartige Sekundärstrukturen sind bei der RT-PCR weniger problematisch, da der RTSchritt hier bei $63^{\circ} \mathrm{C}$ durchgeführt wird und diese so leichter aufgebrochen werden können. Die PRA ist auf eine Reaktionstemperatur von höchstens $42^{\circ} \mathrm{C}$ beschränkt und kann in dieser Hinsicht nicht weiter optimiert werden. Um diesen Nachteil auszugleichen nutzt die RPA-Reaktion das Einzelstrang-Bindeprotein GP32 des T4-Phagen. Dieses Protein interagiert sequenzunabhängig mit einzelsträngiger DNS und RNS sowie anderen Proteinen. Es löst Sekundärstrukturen der Nukleinsäuren auf, verbessert die Effektivität verschiedener Enzyme und erhöht so die Ausbeute der Reaktion (Villalva et al. 2001).

In letzter Zeit sind einige weitere isothermale Amplifikationsmethoden für Nukleinsäuren entwickelt worden, welche als Alternative zur RPA dienen könnten (Gill und Ghaemi 2008). Einige dieser Methoden können teilweise bei höheren Temperaturen durchgeführt werden, was sich im Hinblick auf Sekundärstrukturbildung von RNS als Vorteil erweisen könnte. Neben der RPA, die ein zielverstärkendes Verfahren darstellt, existiert die loopmediated amplification (LAMP) und einige signalverstärkende Verfahren, wie zum Beispiel rolling circle amplification (RCA) (Stougaard et al. 2011) und signal mediated amplification (SMART). Außerdem kann zwischen strangverdrängenden (strand displacement amplification (SDA), LAMP, SMART), T7-Promotor basierten Reaktionen (transcription mediated amplification (TMA), nucleic acid sequence-based amplification (NASBA), single primer isothermal amplification (SPIA)) (Leone et al. 1998) und Helikase-abhängiger Amplifikation (helikase-dependent amplification (HDA)) (Vincent et al. 2004) unterschieden werden. Dabei können sowohl unspezifisch interkalierende Fluoreszenzfarbstoffe (z.B. SYBR ${ }^{\circledR}$ Green, EvaGreen ${ }^{\circledR}$ ), Indikatorfarbstoffe wie Hydroxynaphtholblau als auch spezifische Sondensysteme (z.B. TwistAmp ${ }^{\mathrm{TM}}$ exo) zum Nachweis des Amplifikationsproduktes verwendet werden. 
Ein unspezifischer Nachweis des Amplifikationsproduktes durch elektrochemische Messungen mit einem tragbaren Potentiostat und Methylenblau sind ebenfalls möglich. Dabei bindet das Methylenblau unspezifisch an DNS und wird so immobilisiert. Dies verursacht eine messbare Veränderung der elektrischen Leitfähigkeit des Reaktionsansatzes (Nagatani et al. 2011). Ein denkbares Alternativverfahren für den Feldeinsatz im ESEQuant Tube Scanner wäre beispielsweise die Loop-Mediated Isothermal Amplification (LAMP). Sie benötigt vier bis sechs spezifische Primer, was entsprechend große konservierte Bereiche des viralen Genoms zur Voraussetzung macht. LAMP hat gegenüber RPA den Vorteil, dass die verwendete strangverdrängende Bst (Bacillus stearothermophilus) DNS-Polymerase mit $63{ }^{\circ} \mathrm{C}$ das gleiche Temperaturoptimum wie die zur reversen Transkription verwendete RT aufweist.

So benötigt RT-LAMP zum Nachweis von ca. 120 Molekülen/ 50 $\mu$ l Influenza-A-RNS eine Reaktionsdauer von einer Stunde (Ma et al. 2010). Dieser Wert entspricht den Sensitivitätsangaben von RT-PCR basierten Nachweisreaktionen (Boivin et al. 2004). Die Sensitivität des in dieser Arbeit entwickelten Influenza Nachweises mittels RPA liegt im geringfügig höher angesiedelten Bereich um 218 (Influenza-A) bzw. 131 (Influneza-B) Molekülen. LAMP wurde ebenfalls erfolgreich zum Nachweis der HAdV Spezies D bei Patienten mit epidemischer Keratokonjunktivitis eingesetzt (Nakamura et al. 2012). Die Sensitivität der RPA zum HAdV Nachweis liegt mit 12 bis 131 nachgewiesenen Molekülen im gleichen Bereich wie die Sensitivität von Echtzeit-PCR Reaktionen, die im Bereich zwischen 12,5 (Claas et al. 2005) und 100 Molekülen (Jones et al. 2011) angegeben wird.

Dem durch die höhere Reaktionstemperatur erzielten theoretischen Vorteil der LAMP beim Nachweis von RNS gegenüber der RT-RPA steht eine Verdreifachung der Reaktionsdauer auf eine Stunde entgegen. Besonders im Falle eines Schnelltestes, der direkt in der Arztpraxis durchgeführt werden soll, erscheint die RPA mit einer Wartezeit von nur 20 Minuten wesentlich praktikabler. Durch den Zusatz von GP32 EinzelstrangBindeprotein zur RPA-Reaktion kann der Nachteil der vermehrten Sekundärstrukturen offenbar ausreichend kompensiert werden. In der Zusammenschau wiesen PCR basierte Verfahren, LAMP und RPA vergleichbare Sensitivitätsgrenzen auf. RPA ist dabei jedoch das am einfachsten und schnellsten durchführbare Verfahren, das am besten in einer Point-of-Care Umgebung anwendbar ist. 


\subsection{Ausblick}

Ein wichtiger Aspekt beim Nachweis von RNS ist die Tatsache, dass reverse Transkriptase nicht im RPA Reagenziensatz enthalten ist. Im Rahmen dieser Arbeit wurde für die RT-RPA Roche Transcriptor RT nachträglich dem Reaktionsgemisch hinzugefügt. Dieses Enzym ist nur in einem glycerinhaltigen Puffer erhältlich und kann deshalb nicht als Lyophilisat in den Reagenziensatz integriert werden. Die Herstellerfirma der RPA vertreibt zum Nachweis von RNS seit Kurzem ein System, das auf der retroviralen MulV (Murine Leukemia Virus) Polymerase basiert. Diese RNS- und DNSabhängige DNS-Polymerase ist direkt im Reagenziensatz enthalten, was den Arbeitsaufwand und die Gefahr von Kontaminationen verringert. Ob dieses Vorgehen zu einer Verbesserung der Sensitivität der RPA beim Nachweis von RNS führt, bleibt abzuwarten.

Außerdem muss die weitere Praxis zeigen, ob es durch den Einsatz der vergleichsweise langen RPA-Primer und Sonden zu einer Verminderung der Spezifität der Reaktion gegenüber Echtzeit-PCR Reaktionen kommen kann. Im Rahmen dieser Arbeit wurde zur Überprüfung der Spezifität bzw. einer eventuellen Kreuzreaktivität lediglich genomische DNS bzw. RNS aller 5 untersuchten Viren in die drei Reaktionen eingesetzt. Es konnte keine Kreuzreaktivität nachgewiesen werden. Weiterführend werden außerhalb dieser Arbeit weitere Tests zur Sensitivität und Spezifität der entwickelten Reaktionen anhand von Patientenproben durchgeführt werden, bevor die Reaktion auf eine noch kompaktere mikrofluidische Plattform übertragen werden kann (Asiello und Baeumner 2011).

Bisher wurden die Messungen in einem tragbaren Fluoreszenz-Photometer (ESEQuant Tube Scanner) durchgeführt (Qiagen 2012). Dieses Gerät ist kleiner als ein Laptop Computer und wurde bereits von der Arbeitsgruppe Weidmann erfolgreich in Feldeinsätzen in Afrika verwendet (Haberstroh und Reiff 2007). Das mirkofluidische Alternativsystem zum Tube Scanner hat etwa die Größe einer CD und wird bereits für andere RPA Reaktionen verwendet. Eine Übertragung der Reaktionen auf diese Plattform ist ein weiterer Schritt auf dem Weg zu einem einfach anzuwendenden Point-of-Care Test. Weiterführend sollte ein Schnelltest zur Diagnostik von Atemwegserkrankungen um andere differentialdiagnostisch wichtige Erreger, wie beispielsweise humane Parainfluenzaviren, RSV und typische bakterielle Erreger von Atemwegsinfektionen erweitert werden. 
Aufgrund der relativ großen Länge der für die RPA eingesetzten Oligonukleotide benötigt die Reaktion eine entsprechend große konservierte Region im viralen Genom, die nicht immer vorhanden ist. Für die hier untersuchten Viren waren diese weitgehend gegeben. Zum Nachweis besonders wenig konservierter Zielsequenzen könnten Alternativen, wie z.B. Rolling-Circle-Amplifikation (RCA) basierte Verfahren besser geeignet sein, da sie eine wesentlich kürzere Hybridisierungsequenz benötigen und sogar einzelne Punktmutationen nachweisen können (Murakami et al. 2009).

Zusammenfassend lässt sich feststellen, dass RPA ein problemlos außerhalb einer Laborumgebung durchzuführendes, sehr schnelles Verfahren zum nukleinsäurebasierten, isothermalen Nachweis viraler Atemwegserreger ist, das eine mit dem Goldstandard Echtzeit-PCR und dem isothermalen Alternativverfahren LAMP vergleichbare Sensitivität aufweist. Dies macht sie besonders geeignet zum Einsatz in einer Point-ofCare Umgebung. Dort kann sie durch eine, im Vergleich mit proteinbasierten Nachweismethoden, wesentlich verbesserte Sensitivität zu einer Optimierung der Versorgung, besonders von Influenzapatienten, beitragen. 


\section{$5 \quad$ Zusammenfassung}

Ziel dieser Arbeit war die Entwicklung von RPA- bzw. RT-RPA-Assays zum isothermalen, nukleinsäurebasierten Point-of-Care-Nachweis von Influenza-A und BVirus sowie differentialdiagnostisch relevanter humaner Adenoviren. Es sollte insbesondere ermittelt werden, ob diese nur 20 Minuten beanspruchenden Reaktionen eine mit der Echtzeit-PCR vergleichbare Sensitivität und Spezifität erreichen. Dazu wurden quantitative Standardverdünnungsreihen synthetischer DNS bzw. RNS aus den konservierten Bereichen der entsprechenden Zielgene hergestellt und zunächst in die Echtzeit-PCR bzw. Echtzeit-RT-PCR eingesetzt. Verschiedene RPA-Primerkandidaten wurden anhand der Standardreihen evaluiert. Die effektivsten RPA-Primerkombinationen wurden acht Mal in gleicher Weise mit einer Standardverdünnungsreihe von 10 bis $10^{7}$ Molekülen auf ihre Sensitivität überprüft. Die 95\%-Nachweisgrenzen der Reaktionen wurden durch Probit-Analyse bestimmt. Die entwickelten Assays sind spezifisch und weisen eine mit der Echtzeit-PCR vergleichbare Sensitivität auf. Sie sind mit geringem apparativen Aufwand sehr schnell durchzuführen (maximal 14 Minuten, vergl. Tabelle 5.1). Zwischen den einzelnen Reaktionen konnte keine Kreuzreaktivität nachgewiesen werden. Weiterführend wird die Sensitivität und Spezifität der Assays anhand von Patientenmaterial evaluiert werden. Anschließend wird die Integration auf eine mikrofluidische Plattform erfolgen.

Tabelle 5.1 Sensitivität von RPA- und Echtzeit-PCR-Assays im Vergleich.

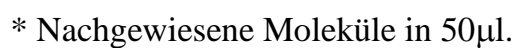

\begin{tabular}{|lcccc|}
\hline \multicolumn{1}{|c}{ Erreger und Zielgen } & $\begin{array}{c}\text { Sensitivität* } \\
\text { Echtzeit-PCR }\end{array}$ & $\begin{array}{c}\text { Sensitivität* } \\
\text { R Läufe }\end{array}$ & $\begin{array}{c}\text { Probit Sensitivität (95\%)* } \\
\text { 8 Läufe }\end{array}$ & $\begin{array}{c}\text { Laufzeit } \\
\text { (mPAn) }\end{array}$ \\
\hline Influenza-A-Virus (M) & $10^{1}-10^{2}$ & $10^{2}-10^{3}$ & $\mathbf{8}$ Läufe & 8 \\
\hline Influenza-B-Virus (HA) & $10^{1}-10^{2}$ & $10^{2}-10^{3}$ & 131 & 13 \\
\hline $\begin{array}{l}\text { Humanes Adenovirus-1 } \\
\text { (Hexon) }\end{array}$ & $10^{1}-10^{2}$ & $10^{1}-10^{2}$ & 12 & 14 \\
\hline $\begin{array}{l}\text { Humanes Adenovirus-4 } \\
\text { (Hexon) }\end{array}$ & $10^{1-10^{2}}$ & $10^{2}-10^{3}$ & 131 & 14 \\
\hline $\begin{array}{l}\text { Humanes Adenovirus-7 } \\
\text { (Hexon) }\end{array}$ & $10^{1}$ & $10^{1}-10^{2}$ & 16 & 8 \\
\hline
\end{tabular}




\section{$6 \quad$ Anhang}

6.1 Alignments der Standardamplikons

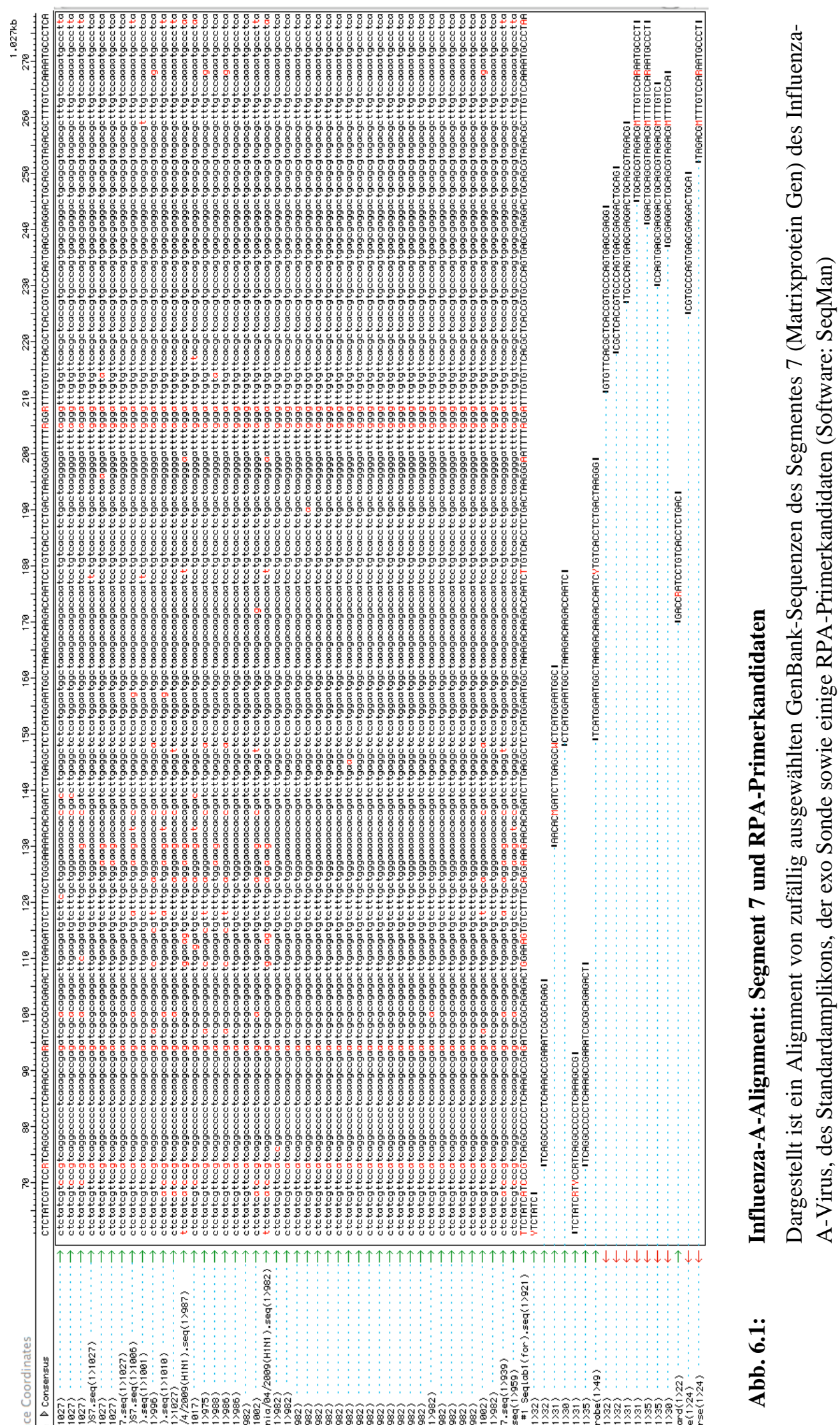




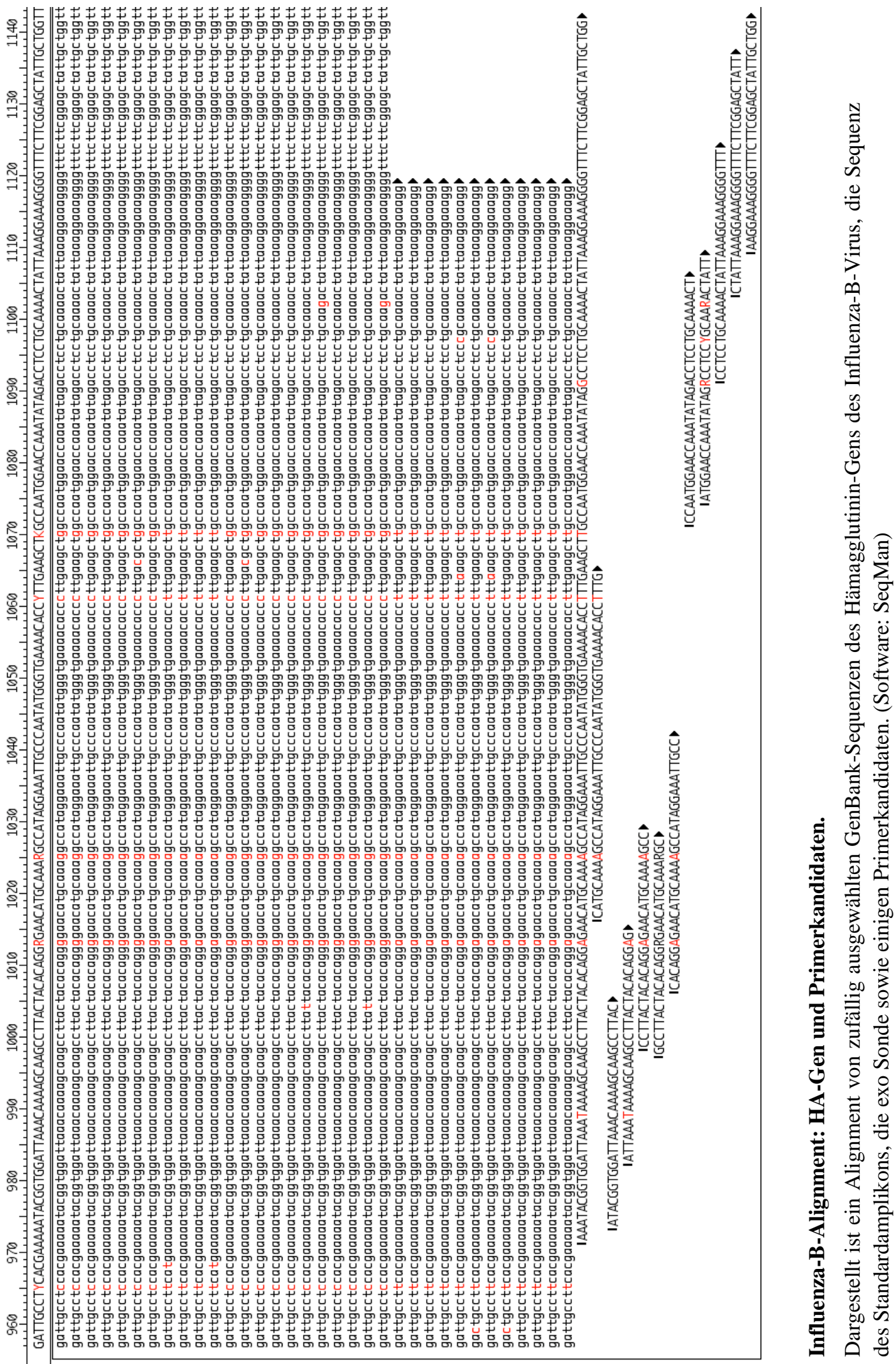

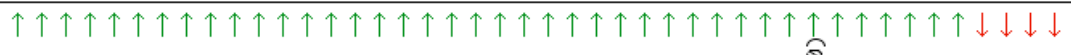
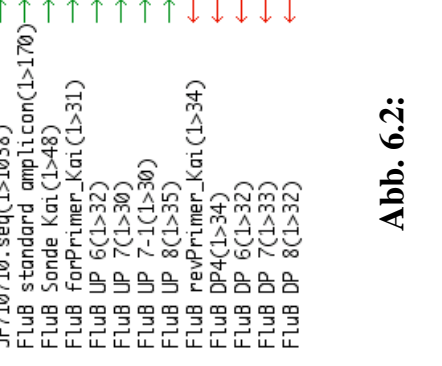


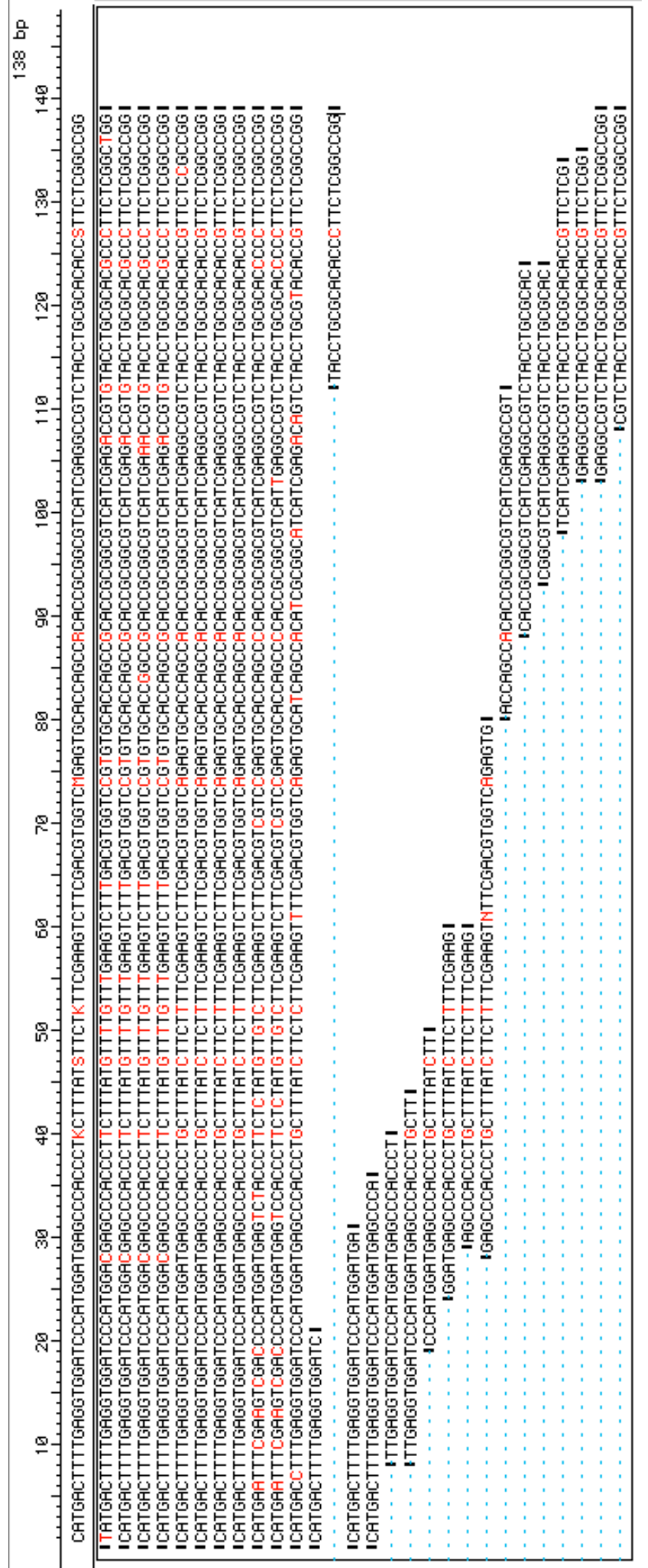

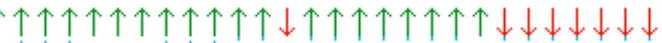

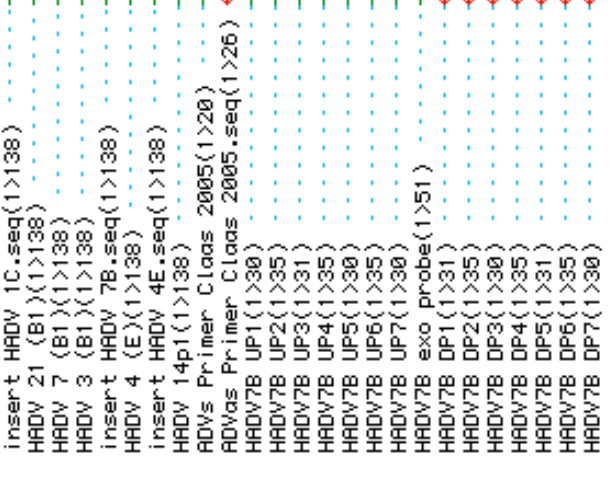

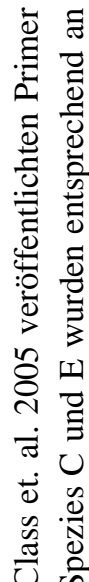

気

.

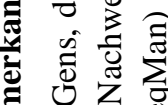

范

离

$\oplus$ 它

·艹

ڤ

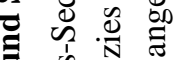

छ

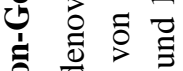

远

范密艺

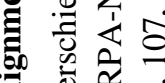

¿

节

芯哭劳

ปี

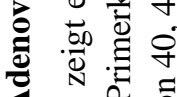

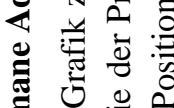

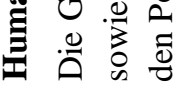

$\ddot{n}$
$\dot{0}$
$\dot{0}$ 


\section{$7 \quad$ Literaturverzeichnis}

Andrewes CH, Smith W, Laidlaw PP (1934): The susceptibility of mice to the viruses of human and swine influenza. Lancet (223):859-862.

Asiello PJ, Baeumner AJ (2011): Miniaturized isothermal nucleic acid amplification, a review. Lab Chip;11(8):1420-1430.

Balabanova Y, Gilsdorf A, Buda S, Burger R, Eckmanns T, Gartner B, Gross U, Haas W, Hamouda O, Hubner J, et al. (2011): Communicable diseases prioritized for surveillance and epidemiological research: results of a standardized prioritization procedure in Germany, 2011. PLoS One; $\underline{6(10)}$ :e25691.

Barenfanger J, Drake C, Leon N, Mueller T, Troutt T (2000): Clinical and financial benefits of rapid detection of respiratory viruses: an outcomes study. J Clin Microbiol;38(8):2824-2828.

Bertani G (1951): Studies on lysogenesis. I. The mode of phage liberation by lysogenic Escherichia coli. J Bacteriol; $62(3): 293-300$.

Boivin G, Cote S, Dery P, De Serres G, Bergeron MG (2004): Multiplex real-time PCR assay for detection of influenza and human respiratory syncytial viruses. J Clin Microbiol;42(1):45-51.

Chou CC, Lee TT, Chen CH, Hsiao HY, Lin YL, Ho MS, Yang PC, Peck K (2006): Design of microarray probes for virus identification and detection of emerging viruses at the genus level. BMC Bioinformatics; $7: 232$.

Claas EC, Schilham MW, de Brouwer CS, Hubacek P, Echavarria M, Lankester AC, van Tol MJ, Kroes AC (2005): Internally controlled real-time PCR monitoring of adenovirus DNA load in serum or plasma of transplant recipients. J Clin Microbiol;43(4):1738-1744.

Echavarria MS, Ray SC, Ambinder R, Dumler JS, Charache P (1999): PCR detection of adenovirus in a bone marrow transplant recipient: hemorrhagic cystitis as a presenting manifestation of disseminated disease. J Clin Microbiol;37(3):686-689.

Falsey AR, Murata Y, Walsh EE (2007): Impact of rapid diagnosis on management of adults hospitalized with influenza. Arch Intern Med;167(4):354-360.

Fields BN, Knipe DM, Howley PM: Fields virology, (5th ed), Wolters Kluwer Health/Lippincott Williams \& Wilkins, Philadelphia 2007.

Förster T (1948): Zwischenmolekulare Energiewanderung und Fluoreszenz. Ann Phys;부(1-2):55-75.

Gardner SN, Kuczmarski TA, Vitalis EA, Slezak TR (2003): Limitations of TaqMan PCR for detecting divergent viral pathogens illustrated by hepatitis $\mathrm{A}, \mathrm{B}, \mathrm{C}$, and $\mathrm{E}$ viruses and human immunodeficiency virus. J Clin Microbiol;1⑹:2417-2427.

Garten RJ, Davis CT, Russell CA, Shu B, Lindstrom S, Balish A, Sessions WM, Xu X, Skepner E, Deyde V, et al. (2009): Antigenic and genetic characteristics of swineorigin 2009 A(H1N1) influenza viruses circulating in humans. Science;325(5937):197-201.

Gill P, Ghaemi A (2008): Nucleic acid isothermal amplification technologies: a review. Nucleosides Nucleotides Nucleic Acids;27(3):224-243.

Haas W, Buchholz U, Grüber A, Guignard A, Leitmeyer K, Sagebiel D, Schweiger B, Uphoff H: Abschlussbericht der Influenzasaison 2004/05 der Arbeitsgemeinschaft 
Influenza (AGI) unter Leitung des Robert-Koch-Instituts (RKI), 2005, www.influenza.rki.de/agi.

Haberstroh K, Reiff EC. Fluoreszenzmessung wird alltagstauglich In: Sensortechnik aktuell, Oldenbourg Industrieverlag, München 2007:29-33.

Heim A, Ebnet C, Harste G, Pring-Akerblom P (2003): Rapid and quantitative detection of human adenovirus DNA by real-time PCR. J Med Virol;70(2):228-239.

Helling RB, Goodman HM, Boyer HW (1974): Analysis of endonuclease R-EcoRI fragments of DNA from lambdoid bacteriophages and other viruses by agarosegel electrophoresis. J Virol;14(5):1235-1244.

Invitrogen: TA Cloning ${ }^{\circledR} \quad$ Kit Dual Promoter (pCR $\left.{ } I I\right) \quad$ User Guide, 2012, lifetechnologies.com.

Jankrift KP: Krankheit und Heilkunde im Mittelalter, Wiss. Buchges., Darmstadt 2003.

Johnson NP, Mueller J (2002): Updating the accounts: global mortality of the 1918-1920 "Spanish" influenza pandemic. Bull Hist Med;76(1):105-115.

Jones MS, Hudson NR, Gibbins C, Fischer SL (2011): Evaluation of type-specific realtime PCR assays using the LightCycler and J.B.A.I.D.S. for detection of adenoviruses in species HAdV-C. PLoS One; $\underline{6(10)}$ :e26862.

Krause G (2008): Prioritisation of infectious diseases in public health--call for comments. Euro Surveill; $\underline{13(40)}$.

Kuo KW, Leung MF, Leung WC (1997): Intrinsic secondary structure of human TNFR-I mRNA influences the determination of gene expression by RT-PCR. Mol Cell Biochem; 177(1-2):1-6.

Leone G, van Schijndel H, van Gemen B, Kramer FR, Schoen CD (1998): Molecular beacon probes combined with amplification by NASBA enable homogeneous, real-time detection of RNA. Nucleic Acids Res;26(9):2150-2155.

Ma XJ, Shu YL, Nie K, Qin M, Wang DY, Gao RB, Wang M, Wen LY, Han F, Zhou SM, et al. (2010): Visual detection of pandemic influenza A H1N1 Virus 2009 by reverse-transcription loop-mediated isothermal amplification with hydroxynaphthol blue dye. J Virol Methods;167(2):214-217.

Martiny E: Die Influenza oder Grippe, eine contagiös-epidemische Krankheit, Bernhard Friedrich Voigt, Weimar 1835.

McCulloch CE, Searle SR: Generalized, linear, and mixed models, John Wiley \& Sons, New York 2001.

Medina RA, Garcia-Sastre A (2011): Influenza A viruses: new research developments. Nat Rev Microbiol;9(8):590-603.

Modrow S: Molekulare Virologie, Spektrum Akad. Verl., Heidelberg 2010.

Morens DM, Taubenberger JK (2010): Historical thoughts on influenza viral ecosystems, or behold a pale horse, dead dogs, failing fowl, and sick swine. Influenza Other Respi Viruses;ㄴ(6):327-337.

Morens DM, Taubenberger JK (2011): Pandemic influenza: certain uncertainties. Rev Med Virol;21:262-284.

Mullis KB, Faloona FA (1987): Specific synthesis of DNA in vitro via a polymerasecatalyzed chain reaction. Methods Enzymol;155:335-350. 
Murakami T, Sumaoka J, Komiyama M (2009): Sensitive isothermal detection of nucleicacid sequence by primer generation-rolling circle amplification. Nucleic Acids Res; $37(3): \mathrm{e} 19$.

Nagatani N, Yamanaka K, Saito M, Koketsu R, Sasaki T, Ikuta K, Miyahara T, Tamiya E (2011): Semi-real time electrochemical monitoring for influenza virus RNA by reverse transcription loop-mediated isothermal amplification using a USB powered portable potentiostat. Analyst;136(24):5143-5150.

Nakamura M, Hirano E, Kowada K, Ishiguro F, Yamagishi Z, Adhikary AK, Hanaoka N, Okabe N, Taniguchi K, Fujimoto T (2012): Surveillance of adenovirus D in patients with epidemic keratoconjunctivitis from Fukui Prefecture, Japan, 19952010. J Med Virol;4(1):81-86.

Pfeiffer R (1892): Vorläufige Mittheilungen über die Erreger der Influenza. Dtsch Med Wochenschr (18):28.

Piepenburg O, Armes N (2007): Biochemical Solutions for Portable Nucleic Acid Testing. BioWorld Europe;01: 38-41.

Piepenburg O, Williams CH, Stemple DL, Armes NA (2006): DNA detection using recombination proteins. PLoS Biol;4(7):e204.

Qiagen: $\quad$ ESEQuant Tube 2012, http://www.qiagen.com/Products/ESEQuantTubeScanner.aspx?r=603.

Robert-Koch-Institut: Epidemiol Bull Nr.41, 2009a, www.rki.de.

Robert-Koch-Institut: Epidemiol Bull Nr.43, 2009b, www.rki.de.

Robert-Koch-Institut: RKI-Ratgeber für Ärzte: Influenza, 2011, www.rki.de.

Sambrook J, Russell DW: Molecular cloning : a laboratory manual, (3rd ed), Cold Spring Harbor Laboratory Press, Cold Spring Harbor, N.Y. 2001.

Sanger F, Nicklen S, Coulson AR (1977): DNA sequencing with chain-terminating inhibitors. Proc Natl Acad Sci U S A; 74(12):5463-5467.

SantaLucia J, Jr. (1998): A unified view of polymer, dumbbell, and oligonucleotide DNA nearest-neighbor thermodynamics. Proc Natl Acad Sci U S A;95(4):1460-1465.

Schmager A (1968): Grippeprophylaxe. Dtsch Arztebl;65:1555.

Schweiger B. Virologische Grundlagen und Labordiagnostik. In: Influenza: Prävention, Diagnostik, Therapie und öffentliche Gesundheit, HAAS W (Hrsg.), Urban und Fischer, München 2009:S.55-79.

SIB: ViralZone, Schweizer Institut für Bioinformatik, 2012, www.expasy.org/viralzone.

Spackman E, Senne DA, Myers TJ, Bulaga LL, Garber LP, Perdue ML, Lohman K, Daum LT, Suarez DL (2002): Development of a real-time reverse transcriptase PCR assay for type A influenza virus and the avian H5 and H7 hemagglutinin subtypes. J Clin Microbiol;ㅇ⑼:3256-3260.

Stougaard M, Juul S, Andersen FF, Knudsen BR (2011): Strategies for highly sensitive biomarker detection by Rolling Circle Amplification of signals from nucleic acid composed sensors. Integr Biol (Camb);3(10):982-992.

Thompson WW, Shay DK, Weintraub E, Brammer L, Cox N, Anderson LJ, Fukuda K (2003): Mortality associated with influenza and respiratory syncytial virus in the United States. JAMA;289(2):179-186. 
Villalva C, Touriol C, Seurat P, Trempat P, Delsol G, Brousset P (2001): Increased yield of PCR products by addition of T4 gene 32 protein to the SMART PCR cDNA synthesis system. Biotechniques;31(1):81-83, 86.

Vincent M, Xu Y, Kong H (2004): Helicase-dependent isothermal DNA amplification. EMBO Rep;5(8):795-800.

Vogel GE: Praxishandbuch Influenza: verstehen, vorbeugen, erkennen und behandeln, Thieme, Stuttgart 2011.

Vologodski AV: Topology and physics of circular DNA, CRC Press, Boca Raton 1992.

Wallace RB, Shaffer J, Murphy RF, Bonner J, Hirose T, Itakura K (1979): Hybridization of synthetic oligodeoxyribonucleotides to phi chi 174 DNA: the effect of single base pair mismatch. Nucleic Acids Res;6(11):3543-3557.

Walsh EE, Cox C, Falsey AR (2002): Clinical features of influenza A virus infection in older hospitalized persons. J Am Geriatr Soc;50(9):1498-1503.

Welliver RC (2003): Respiratory syncytial virus and other respiratory viruses. Pediatr Infect Dis J;22(2 Suppl):S6-10; discussion S10-12.

Wishaupt JO, Russcher A, Smeets LC, Versteegh FG, Hartwig NG (2011): Clinical impact of RT-PCR for pediatric acute respiratory infections: a controlled clinical trial. Pediatrics;128(5):e1113-1120.

Witte W. Epidemien und Pandemien. In: Influenza Prävention, Diagnostik, Therapie und öffentliche Gesundheit, HAAS W (Hrsg.), Urban und Fischer, München 2009:121.

Wolf J: Die Influenza Epidemie 1889-1892, Ferdinand Enke, Stuttgart 1892. 


\section{Danksagung}

Mein Dank gilt zuerst Prof. Dr. med. Frank T. Hufert für die freundliche Aufnahme in seine Arbeitsgruppe und meinem Betreuer PD. Dr. rer. nat. Manfred Weidmann für die Anregung zur Arbeit an diesem interessanten Forschungsthema. Besonderer Dank gilt ebenfalls Dr. Meik Dilcher, der jederzeit mit bemerkenswerter Geduld meine zahlreichen Fragen beantwortete und mir bei den im Forschungsalltag unvermeidlichen Rückschlägen immer wieder mit neuen Lösungsansätzen weiterhalf. Außerdem gebührt ihm großer Dank für das Bereitstellen von Influenza-A-RNS, ohne die meine Forschung so nicht möglich gewesen wäre. Für die unermüdliche und professionelle Einführung in die Praxis eines virologischen Labors, danke ich dem gesamten Laborteam der Arbeitsgruppe von Prof. Dr. med. F. Hufert.

Ich danke auch Dipl.-Math. Benjamin Becker aus der Abteilung medizinische Statistik der Universitätsmedizin Göttingen, der es mir durch seine besonnenen Erklärungen erleichterte, das Probit-Modell für meine Forschung nutzbar zu machen. Des Weiteren danke ich PD Dr. med. Albert Heim (Medizinische Hochschule Hannover) für das freundliche Zur-Verfügung-Stellen von HADV-DNS.

Ich danke dem Schweizer Institut für Bioinformatik für die Erlaubnis, die graphischen Darstellungen der Virionen zu verwenden.

Nicht zuletzt bin ich allen dankbar, die mir bei der Korrektur und Überarbeitung meiner Dissertation mit kritischen Anregungen und Nachfragen weitergeholfen haben. 